\title{
Uzupełnienia do flory mchów Pasma Policy w polskich Karpatach Zachodnich
}

\author{
Ryszard Ochyra, Adam Stebel, †Henryk Klama i Katarzyna Bityk
}

Ochyra, R., Stebel, A., †Klama, H. And BiŁyK, K. 2020. Addenda to the moss flora of the Polica Range in the Polish Western Carpathians. Fragmenta Floristica et Geobotanica Polonica 27(2): 203-252. e-ISSN 2449-8890, ISSN 1640-629X.

\begin{abstract}
An annotated list of 31 moss species from the Polica Range in the Beskidy Zachodnie Mountains, Polish Western Carpathians, is provided. Of these, 15 species represent new records for this mountain range, while 16 species have so far been considered to be very rare or rare in this area. Tortula mucronifolia Schwägr. is excluded from the moss flora of the Polica Range and the Beskidy Zachodnie. Bucklandiella affinis is recorded for the second time in the Polish Western Carpathians. This species along with Schistidium trichodon var. trichodon is a new addition to the moss flora of the Beskidy Zachodnie, whilst Ditrichum pusillum, Meesia uliginosa and Schistidium elegantulum represent second records of the species concerned in these mountains. Four species of moss, Schistidium elegantulum, S. trichodon var. trichodon, Bucklandiella affinis, Syntrichia latifolia and Meesia uliginosa are known to occur exclusively in the Polica Range within the Beskid Wysoki. Distribution of all species in the study area is mapped and for some species distribution maps in the Polish Carpathians are provided. The moss flora of the Polica Range consists currently of 278 species and 5 varieties. The diversity of the moss flora in the Beskidy Zachodnie is discussed. The richest muscoflora has the Beskid Wysoki (355 species, 1 subspecies and 11 varieties) which is followed by the Beskid Śląski (304 species and 3 varieties), the Gorce (286 species and 9 varieties) and the Beskid Mały (260 species and 8 varieties). Within the Beskid Wysoki Range the richest moss flora has the Babia Góra massif (280 species, 1 subspecies and 11 varieties) and Polica Range (278 species and 5 varieties).
\end{abstract}

KEY WORDS: Beskidy Zachodnie, Bryophyta, distribution, diversity, endangered and protected species, Poland, Polish Western Carpathians

R. Ochyra (autor korespondencyjny), K. Bityk, Instytut Botaniki im. W. Szafera Polskiej Akademii Nauk, ul. Lubicz 46, 31-512 Kraków,Polska; e-mail: r.ochyra@botany.pl, k.bilyk@botany.pl

A. Stebel, Katedra i Zakład Botaniki Farmaceutycznej i Zielarstwa, Wydziat Nauk Farmaceutycznych, Ślaski Uniwersytet Medyczny w Katowicach, ul. Ostrogórska 30, 41-200 Sosnowiec, Polska; e-mail: astebel@sum.edu.pl

H. Klama, Instytut Ochrony i Inżynierii Środowiska, Akademia Techniczno-Humanistyczna w BielskuBiatej, ul. Willowa 2, 43-309 Bielsko-Biała, Polska; e-mail: hklama@ath.bielsko.pl

\section{WSTĘP}

Pasmo Policy jest wybitną, wyraźnie odróżniającą się jednostką fizjograficzną w polskich Karpatach Zachodnich, której nazwa pochodzi od najwyższego szczytu - Policy - osiągającego wysokość 1369 m n.p.m. Według najnowszej regionalizacji geograficznej Polski 
KondRACKIEGO (2014), grzbiet Policy stanowi wschodnią część Pasma Babiogórskiego i wraz z nim wchodzi w skład Beskidu Wysokiego, zwanego także Beskidem Żywieckim (Ryc. 1). Pasmo Policy zaczyna się na Przełęczy Krowiarki, która oddziela go od Pasma Babiogórskiego, skąd jego główny grzbiet biegnie w kierunku północno-wschodnim, kończąc się w dolinie Skawy koło Osielca (Ryc. 2). Poza Policą, najwyższe kulminacje pasmo to osiąga na szczytach: Czyrniec, noszący również inną nazwę Syhlec - 1318 m n.p.m., Kiczorka - 1298 m n.p.m. i Okraglica - 1239 m n.p.m. Północno-zachodnie stoki Pasma Policy opadają do doliny Skawicy, gdzie położone są dwie duże miejscowości, Zawoja i Skawica. Natomiast przez południowo-zachodnią część Pasma Policy biegnie dział wodny bałtycko-czarnomorski (KONDRACKI 2014). Potok Bystrzanka, będący dopływem Skawy

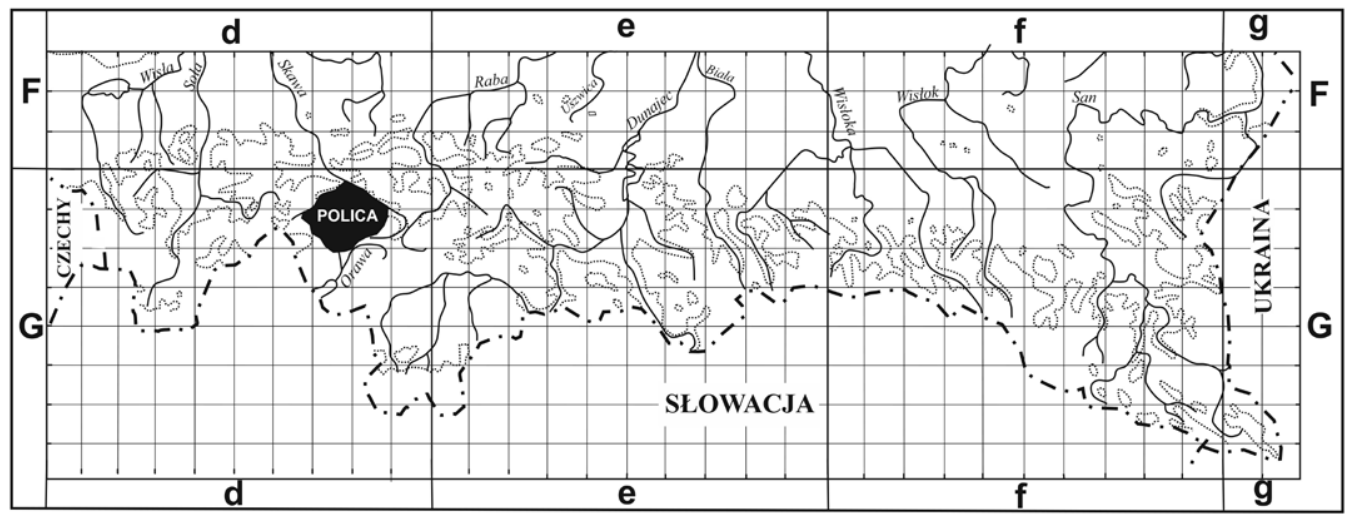

Ryc. 1. Położenie Pasma Policy w polskich Karpatach

Fig. 1. Location of the Polica Range in the Polish Carpathians

i przepływający przez leżącą w jego dolinie miejscowość Sidzina u podnóża południowo-wschodnich zboczy pasma, należy do zlewni Morza Bałtyckiego. Natomiast potok Zubrzyca i jego dopływy, który z kolei wpada do Czarnej Orawy, należy już do zlewni Morza Czarnego. W szczytowych partiach północnych stoków Policy został utworzony w 1972 r. „Rezerwat na Policy im. prof. Zenona Klemensiewicza” (AlEXANDrowicz 1989), w którym dominują dobrze zachowane fragmenty puszczy świerkowej Plagiothecio-Piceetum (PASIERBeK i in. 2004). W 1998 r. utworzono obok rezerwat „Na Policy” (ANONIM 1998).

Pasmo Policy jest jednym z najlepiej zbadanych pod względem botanicznym pasm górskich w Beskidach Zachodnich (STuchlikowa \& Stuchlik 1962; STuchlikowa 1967; STuCHLIK 1968a, b; PASIERBEK i in. 2004). Równie dobrze zbadana jest flora mchów, chociaż przez długi okres czasu Pasmo Policy było skrzętnie omijane przez briologów, a pierwsze dane na temat jego brioflory pochodzą z wyżej wymienionych prac geobotanicznych i fitosocjologicznych B. Stuchlikowej i L. Stuchlika. Niemniej jednak w latach 60. i 70. ubiegłego wieku prowadzone były intensywne badania terenowe flory mszaków w Paśmie Policy przez M. Kuca i R. Ochyrę. Ich wyniki zostały opublikowane dopiero w 2004 r. w formie lokalnej Flory, w której z Pasma Policy podano 264 gatunki i 5 odmian mchów (STEBEL i in. 2004). 


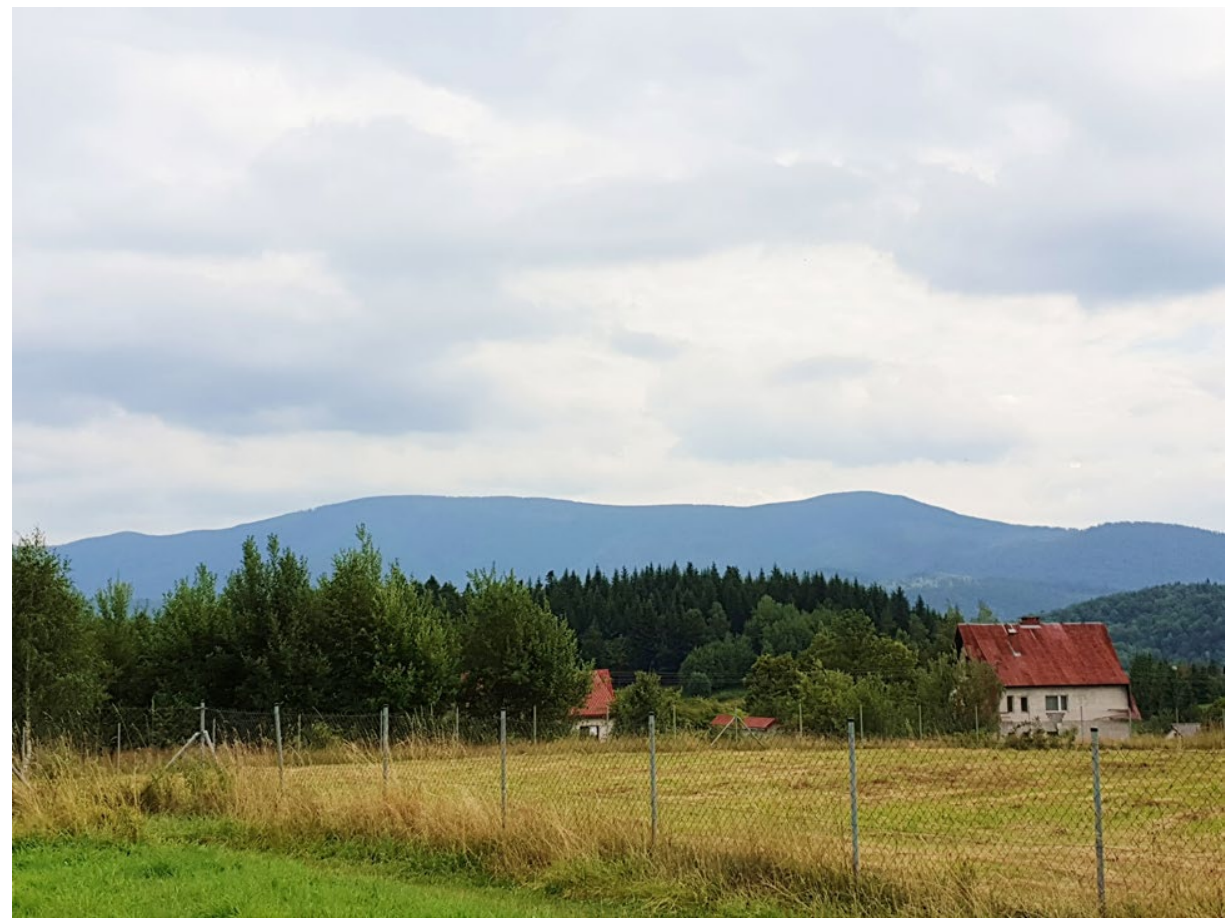

Ryc. 2. Widok na północne stoki Pasma Policy z Przełęczy Przysłop w Beskidzie Makowskim (fot. A. Stebel, 10.08.2019)

Fig. 2. A view of the northern slope of the Polica Range from the Przełęcz Przysłop Pass in the Beskid Makowski Range (photo by A. Stebel, 10.08.2019)

Badania terenowe przeprowadzone przez autorów w Paśmie Policy w ostatnich dwóch latach oraz rewizja niektórych dawniej zebranych okazów doprowadziła do odkrycia szeregu gatunków mchów nowych dla tego pasma lub znanych stąd tylko z pojedynczych stanowisk. Do tej pory jedynie najciekawsze z tych znalezisk, poświęcone Hookeria lucens (Hedw.) Sm. zostało opublikowane (KLAMA \& OchYRA 2018). Niniejsze opracowanie zawiera podsumowanie informacji o wszystkich nowych znaleziskach mchów w Paśmie Policy, dokonanych po 2004 r.

\section{MATERIAE I METODY}

W 2017 roku R. Ochyra i H. Klama przeprowadzili uzupełniające badania terenowe do przygotowywanego aktualnie opracowania flory wątrobowców Pasma Policy, opartej głównie na materiałach zebranych przez pierwszego z nich w $1978 \mathrm{r}$. Prowadzone one były na kilku stanowiskach, m.in. na południowo-wschodnich stokach Policy, Okraglicy, klifie Łysina i w najbliższym otoczeniu, w górnym biegu Skawicy Górnej oraz w lesie Sitarka w Skawicy Suchej Górze. Natomiast A. Stebel zebrał w 2019 r. kilka ciekawych gatunków w Zawoi Centrum (Ryc. 3) i Zawoi Policzne, w tym trzy nowe dla badanego terenu gatunki z rodzajów Orthotrichum Hedw., Lewinskya F.Lara, Garilleti \& Goffinet i Syntrichia Brid. Ponadto, rewizja kilku dawniej zebranych okazów z rodzaju Schistidium Bruch \& Schimp. oraz okazów naziemnych mchów dostarczyły dalszych interesujących gatunków nowych dla Pasma Policy, które występowały w domieszce $\mathrm{z}$ gatunkami przewodnimi w danej kolekcji. 


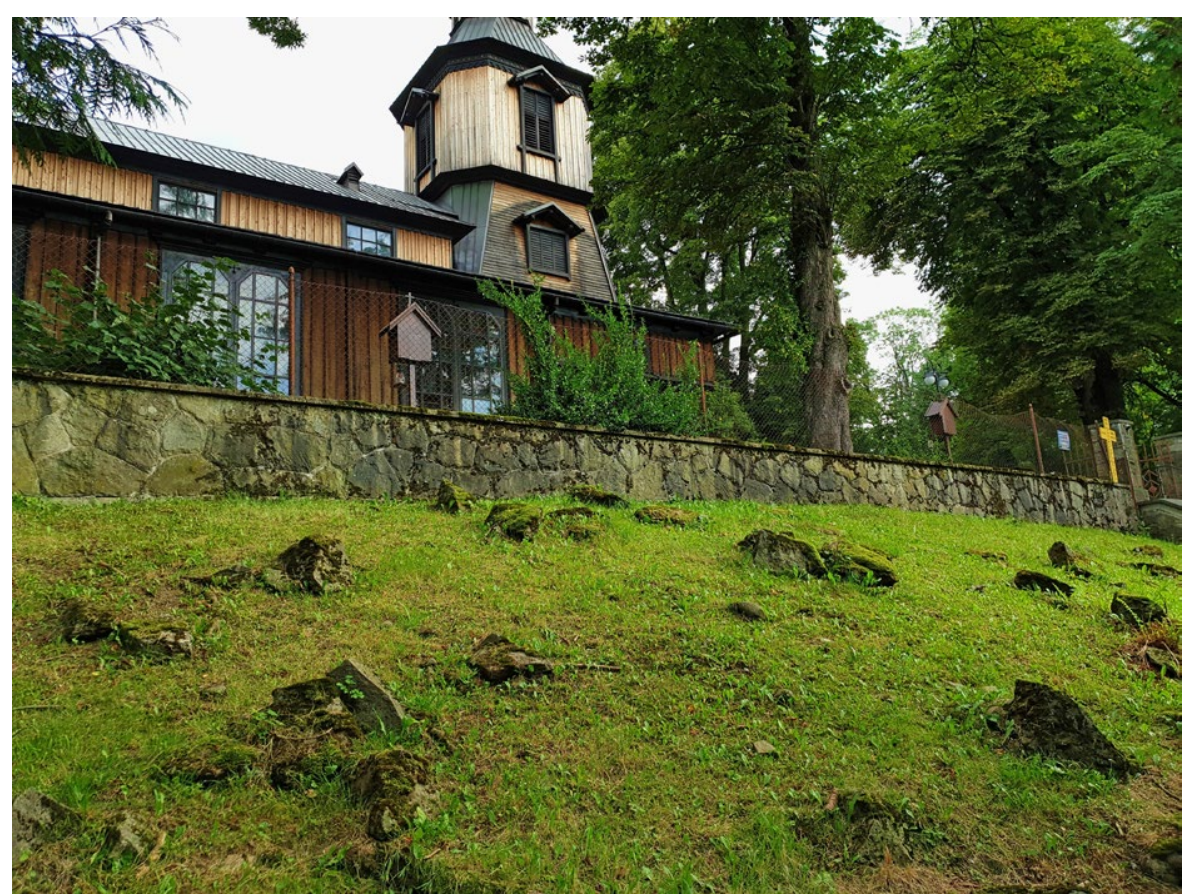

Ryc. 3. Kościół w Zawoi Centrum, miejsce występowania Encalypta streptocarpa, Syntrichia latifolia i Tortula subulata (fot. A. Stebel, 10.08.2019)

Fig. 3. The church in Zawoja Centrum, a locality of Encalypta streptocarpa, Syntrichia latifolia and Tortula subulata (photo by A. Stebel, 10.08.2019)

Gatunki nowe i rzadkie dla badanego terenu zostały zestawione w osobnych listach w porządku systematycznym według rodzin za OCHYRA i in. (2003). Dla każdego gatunku podano: położenie, kwadrat ATMOS, współrzędne geograficzne, wysokość nad poziom morza, dane siedliskowe, datę zbioru i zielnik(-i), w których przechowywane są okazy oraz odpowiednie komentarze taksonomiczne i fitogeograficzne. Rozmieszczenie wszystkich gatunków zostało przedstawione na mapach punktowych w Paśmie Policy, a dla dwunastu rzadkich gatunków w całych polskich Karpatach w oparciu o siatkę kwadratów ATMOS (OCHYRA \& SZMAJDA 1981). Gatunki znalezione po raz pierwszy w Beskidach Zachodnich oznaczone są gwiazdką (*).

\section{LISTA GATUNKÓW}

Poniższy wykaz obejmuje dwie osobne listy. W pierwszej z nich uwzględnionych jest 15 gatunków nowych dla Pasma Policy, natomiast w drugiej znalazło się 16 gatunków, które były dotychczas bardzo rzadkie lub rzadkie we florze mchów badanego obszaru. W obu listach taksony ułożone są w porządku systematycznym, zgodnie z systemem zaakceptowanym w wykazie mchów Polski (OchYRA i in. 2003). Również nazewnictwo taksonów przyjęto za tym opracowaniem, chociaż uwzględnione tu zostały najnowsze ujęcia taksonomiczne rodzajów w rodzinach Grimmiaceae (BEDNAREK-OCHYRA i in. 2014, 2015; SAWICKI i in. 2015) i Orthotrichaceae (PLÁŠEK i in. 2015, 2016; LARA i in. 2016; SAWICKI i in. 2017). 


\title{
Gatunki nowe dla flory mchów Pasma Policy
}

\author{
Ditrichaceae Limpr.
}

Ditrichum lineare (Sw.) Lindb.

(Ryc. 4A)

(1) Potok Rotnia w Limowie, 6 km na południowy-wschód od Skawicy Dolnej, 480-560 m n.p.m., $49^{\circ} 40^{\prime} 48^{\prime \prime} \mathrm{N}, 19^{\circ} 40^{\prime} 41^{\prime \prime} \mathrm{E}$, na nagiej glebie na brzegu potoku, ATMOS Gd-07, 29.07.1978, Ochyra 2480/78 (KRAM B-225529); (2) Polica, na gliniastej ziemi, ATMOS Gd-17, 10.05.1966, Stuchlik \& Kuc s.n. (KRAM B-142332); (3) na południowy-zachód od przysiółka Kowalowa w Podpolicach, około 5 km na południe od Zawoi Fujacy, w obszarze źródliskowym jednego z orograficznie lewych dopływów Skawicy Górnej, 690-765 m n.p.m., 49 $38^{\prime} 10^{\prime \prime} \mathrm{N}, 19^{\circ} 35^{\prime} 51^{\prime \prime} \mathrm{E}$, na nagiej glebie na ocienionej skarpie przydrożnej, ATMOS Gd-17, 5.10.2017, Ochyra \& Klama 1480/17 (KRAM B-243727).

Ditrichum lineare jest bardzo rzadkim gatunkiem, znanym w Polsce tylko z południowej części kraju, głównie z gór (SzAFRAN 1957; KUC 1964). W XIX w. zbierany był na kilku stanowiskach w Karkonoszach i Górach Izerskich (MiLdE 1869; LIMPRICHT 1876, 1890), a w ubiegłym wieku na Śnieżniku Kłodzkim (LISOwSKI 1956a) w Sudetach. W 2002 r. odnaleziono jego stanowisko w Karpaczu Wilczej Porębie w Karkonoszach (FudALI i in. 2003). Natomiast w Karpatach gatunek ten był tylko raz zbierany w Tatrach w Karpatach Zachodnich (CHAŁUBIŃSKI 1886; OCHYRA \& CiSŁO 1999) oraz jeden raz w Bieszczadach Zachodnich w polskich Karpatach Wschodnich (LISOWSKI 1956b). W ostatnich latach odnaleziony został na Pogórzu Orawsko-Jordanowskim (STEBEL \& VončInA 2014), w Beskidzie Małym (SteBel 2017) oraz w Beskidzie Makowskim [Gd-06, Kurów Jeżowski Dział, brzeg ścierniska, 520 m n.p.m., leg. A. Stebel, 20.09.2003, rev. I. Novotný, 22.10.2006 (SOSN)] (Ryc. 5A). Poza górami, gatunek ten znany jest z kilku rozproszonych stanowisk na Wyżynie Małopolskiej (STEBel 2003a), Wyżynie Woźnicko-Wieluńskiej (BEDNAREKOCHYRA \& OChYRA 1996; STEBel \& KRAJEWSKi 2020), Wyżynie Lubelskiej (KuC 1962; KARCZMARZ \& KuC 1962) i Roztoczu (KuC 1963).

Ditrichum pusillum (Hedw.) Hampe

(Ryc. 4B)

(1) Oblica, $2 \mathrm{~km}$ na południe od Skawicy Górnej i $5 \mathrm{~km}$ na południe od Suchej Beskidzkiej, 540-595 m n.p.m., 49 $39^{\prime} 37^{\prime \prime} \mathrm{N}, 19^{\circ} 37^{\prime} 48^{\prime \prime} \mathrm{E}$, na nagiej glebie na przydrożnej skarpie, ATMOS Gd-07, 11.10.1978, Ochyra 1774/78 (KRAM B-224184); (2) w dolnej części Psiej Doliny na północ od Wielkiej Polany, najdalej na północ wysuniętego przysiółka Zubrzycy Górnej, 800-870 m n.p.m., 49³6'18"N, 19³8'08'E, na nagiej glebie, ATMOS Gd-17, 10.10.1978, Ochyra 347/78 (KRAM B-214697).

Bardzo rzadki gatunek w skali całej Polski, mający główne centrum występowania w pasie wyżyn południowych Polski, gdzie rośnie w rozproszeniu na Wyżynie Śląskiej, Wyżynie Krakowsko-Częstochowskiej i Wyżynie Lubelskiej (Kuc 1964). Poza tym znany m.in. z Pojezierza Iławskiego i Pojezierza Chełmińsko-Dobrzyńskiego na północy kraju (DiEtzow 1938), Kotliny Oświęcimskiej (Podgórza Wilamowickiego) (STEBEL 2004a) oraz z Karpat, gdzie był zbierany w Tatrach (Rehmann 1865; ChAŁubińsKi 1886; Lisowski 1959; OCHYRA \& CisŁo 1999), Kotlinie Orawsko-Nowotarskiej (CHAŁUBIŃSKi 1886), Skalicach Spiskich (OCHYRA 1984), Beskidzie Sądeckim (REHMAN 1869; KRUPA 1882 jako Leptotrichum tortile (Brid.) Hampe; MAMCZARZ 1977) oraz na Pogórzu Wielickim (KRUPA 1882) i Pogórzu Spisko-Gubałowskim (KRUPA 1888), w Bieszczadach Zachodnich (LisowsKi 1956c), 

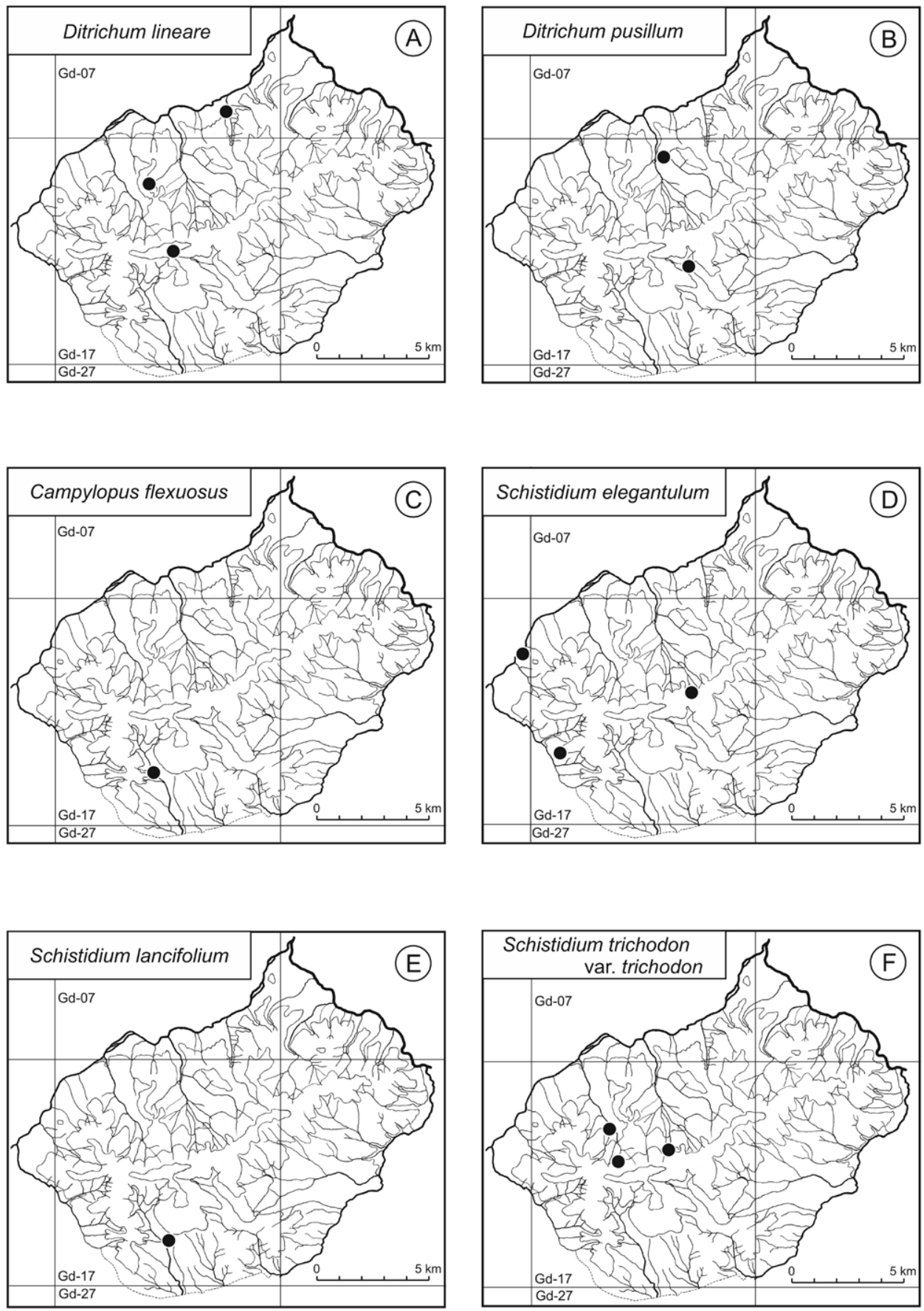

Ryc. 4. Rozmieszczenie gatunków mchów nowych dla Pasma Policy

Fig. 4. Distribution of moss species new to the Polica Range

Ditrichum lineare (A), D. pusillum (B), Campylopus flexuosus (C), Schistidium elegantulum (D), S. lancifolium (E), S. trichodon var. trichodon $(\mathrm{F})$ 

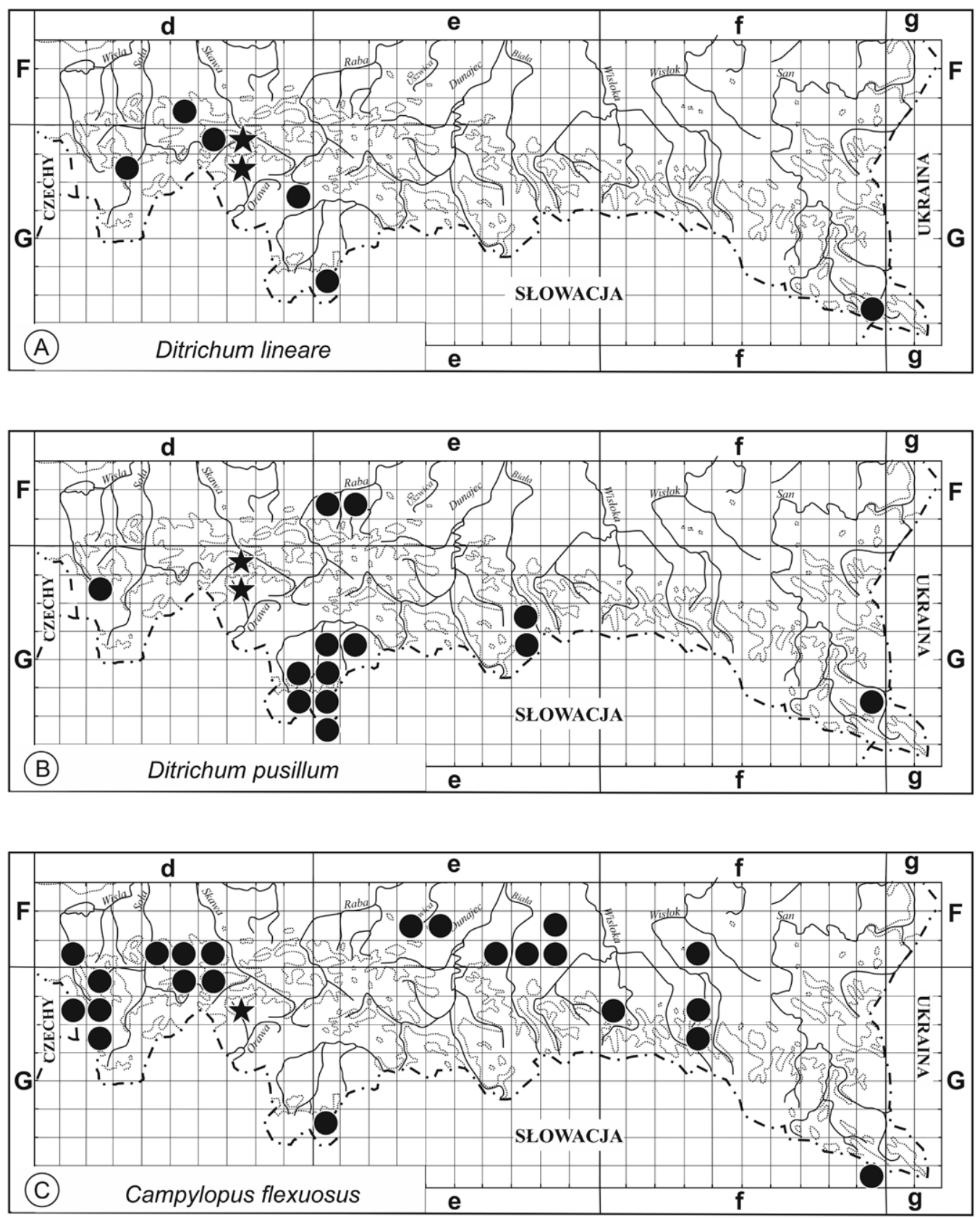

Ryc. 5. Aktualne rozmieszczenie geograficzne wybranych gatunków mchów w polskich Karpatach. Stanowiska w Paśmie Policy zaznaczone gwiazdką

Fig. 5. Current geographical distribution of selected moss species in the Polish Carpathians. Localities in the Polica Range marked with an asterisk

Ditrichum lineare (A), D. pusillum (B), Campylopus flexuosus (C) 
a ostatnio także w Beskidzie Śląskim w Beskidach Zachodnich (STEBEL 2006a) (Ryc. 5B). Nowe stanowiska Ditrichum pusillum w Paśmie Policy są więc trzecim znaleziskiem tego gatunku w Beskidach Zachodnich.

\section{Dicranaceae Schimp.}

Campylopus flexuosus (Hedw.) Brid.

(Ryc. 4C)

Ochlipów, między Przełęczą Krowiarki i Zubrzycą Górną w południowej części doliny Białego Potoku, między Polaną Knopówki i Polaną Nowiny na południowym podnóżu Policy, 909 m n.p.m., 49³5'57"N, $19^{\circ} 36^{\prime} 44^{\prime \prime} \mathrm{E}$, na ziemi przy ścieżce w lesie świerkowym, ATMOS Gd-17, 7.07.2017, Ochyra \& Klama 1722/17 (KRAM B-243383).

Jeszcze ćwierć wieku temu Campylopus flexuosus uważany był za bardzo rzadki gatunek w Polsce, znany z zaledwie 17 stanowisk, z których większość pochodziła z XIX i pierwszej połowy XX w. (RUSIŃSKA 1995). Było to powodem umieszczenia tego gatunku na czerwonej liście mchów zagrożonych w Polsce (ŻARNOWIEC i in. 2004), w efekcie czego znalazł się on na liście gatunków podlegających częściowej ochronie w naszym kraju (ANONIM 2014). Jednak począwszy od końca lat 90. ubiegłego wieku gatunek ten wyraźnie zaczyna się rozprzestrzeniać w Polsce, występując nieraz w wielkiej obfitości na siedliskach antropogenicznych, takich jak przydrożne skarpy, pobocza ścieżek oraz młodniki świerkowe i sosnowe (STEBel 2007; SMOcZYк 2017). W polskich Karpatach C. flexuosus był gatunkiem bardzo rzadkim (Ryc. 5C), rosnącym na pojedynczych, rozproszonych stanowiskach w Rowie Podtatrzańskim (CHAŁUBIŃSKI 1886), na Pogórzu Śląskim (WILCZEK 1936), w Beskidzie Śląskim (SzAFrAn 1965), Beskidzie Niskim (WACŁAWSKA 1957) i w Bieszczadach Zachodnich (LisowsKi 1956c). Obecnie znany jest z szeregu dalszych stanowisk, zarówno na przedpolu Karpat (Pogórze Wiśnickie, Rożnowskie, Ciężkowickie i Dynowskie) (ARMATA 2006; STEBEL 2007, 2015b, 2016a; STEBEL \& VoNČINA 2017), jak i z wielu pasm zachodniobeskidzkich (Beskid Śląski, Beskid Mały, Beskid Makowski, Beskid Wysoki, Kotlina Żywiecka) i Beskidu Niskiego, gdzie gatunek ten rośnie bardzo rzadko, ale z wyraźnymi tendencjami do rozprzestrzeniania się (STEBEL 2006a, 2007, 2010a, 2016b, 2017; STEBEL \& KRAJEWSKI 2020). Odkrycie C. flexuosus w Paśmie Policy jest tego potwierdzeniem.

\section{Grimmiaceae Arn.}

\section{Schistidium elegantulum H.H.Blom}

(Ryc. 4D)

(1) zachodnie zbocze Okrąglicy na wschód od Hali Krupowej, 1180-1230 m n.p.m., 49³7'38"N, $19^{\circ} 33^{\prime} 12^{\prime \prime} \mathrm{E}$, na ścianie obelisku w towarzystwie $S$. crassipilum H.H.Blom i S. dupretii (Thér.) W.A.Weber, ATMOS Gd-17, 12.10.1978, Ochyra 2138A/78 (KRAM B-224386); (2) Zawoja Trybały, 545-550 m n.p.m., 49 39'41"N, 19³3'32"E, ATMOS Gd-07, 7.09.1978, Ochyra 1208A/78 (KRAM B-214962); (3) szosa Karpacka między Policznem i Przełęczą Krowiarki, w odkrytych miejscach na przydrożnych kamieniach, 760-770 m n.p.m., ATMOS Gd-17, 27.08.1999, Stebel s.n. (KRAM B-227171, SOSN-30149).

Rozmieszczenie geograficzne Schistidium elegantulum w Polsce, podobnie jak wielu innych gatunków z grupy S. apocarpum (Hedw) Bruch \& Schimp., jest bardzo słabo poznane, gdyż rodzaj ten nie doczekał się jeszcze krytycznej rewizji taksonomicznej w naszym kraju. 
Aż do połowy lat 90. ubiegłego wieku S. apocarpum traktowany był jako jeden zbiorczy gatunek, który faktycznie obejmuje wiele wybitnych gatunków w Europie, albo dotychczas nieopisanych albo zapomnianych (BLOM 1996). W Polsce do tej pory najczęściej gatunek ten był notowany w Pienińskim Pasie Skałkowym (OCHYRA \& Stebel 2008; STEBel i in. 2010), a ponadto podawany był z Beskidu Śląskiego (PláŠEK \& SteBEL 2002) (Ryc. 6A) oraz z Kotliny Oświęcimskiej i Puszczy Rominckiej (Blom 1996). Odkrycie S. elegantulum w Paśmie Policy utwierdza w przekonaniu, że gatunek ten występuje także w innych pasmach zachodniokarpackich, zwłaszcza że jest on częsty w całej Środkowej Europie (BLOM 1996).

Schistidium lancifolium (Kindb.) H.H.Blom

(Ryc. 4E)

Ochlipów, między Przełęczą Krowiarki i Zubrzycą Górną w południowej części doliny Białego Potoku, między Polaną Knopówki i Polaną Nowiny na południowym podnóżu Policy, 909 m n.p.m., 49³5'57"N, $19^{\circ} 36^{\prime} 44^{\prime \prime} \mathrm{E}$, na przydrożnych głazach piaskowcowych, ATMOS Gd-17, 5.07.2017, Ochyra \& Klama 84/17 (KRAM B-240488).

Schistidium lancifolium jest jednym z najwybitniejszych gatunków w kompleksie $S$. apocarpum, mającym wybitnie ząbkowane brzegi liści w górnej części oraz silnie brodawkowane żebro na stronie grzbietowej w górnej części, z brodawkami zwiększającymi się ku szczytowi liści i osiągającymi wysokość $11 \mu \mathrm{m}$. W Polsce znany jest tylko z gór, prawie wyłącznie z Karpat Zachodnich. Dotychczas najczęściej notowany był w Małych Pieninach (Blom 1996; Ochyra \& Stebel 2008) i Pieninach (Stebel i in. 2010) oraz bardzo rzadko w różnych pasmach zachodniobeskidzkich (Beskid Śląski, Beskid Mały, Beskid Wysoki, Pogórze Orawsko-Jordanowskie) (STEBEL 2006a; STEBEL \& VONČINA 2014). Ostatnio odnaleziony został także w Bieszczadach Zachodnich (STEBEL \& ŻARNOwIEC 2010) (Ryc. 6B). W Sudetach znany jest jak na razie tylko ze Śnieżnika Kłodzkiego (BLOM 1996).

\section{*Schistidium trichodon (Brid.) Poelt var. trichodon}

(Ryc. 4F)

(1) na południowy-zachód od przysiółka Kowalowa w Podpolicach, $5 \mathrm{~km}$ na południe od Zawoi Fujacy, w obszarze źródliskowym jednego z orograficznie lewych dopływów Skawicy Górnej, 690-765 m n.p.m., $49^{\circ} 38^{\prime} 10^{\prime \prime} \mathrm{N}, 19^{\circ} 35^{\prime} 51^{\prime \prime} \mathrm{E}$, na głazie piaskowcowym w lesie świerkowym, ATMOS Gd-17, 5.10.2017, Ochyra \& Klama 1463/17 (KRAM B-243708); (2) Skawica Sucha Góra, Sitarka, 4 km na południe od Skawicy, wzdłuż jednego ze źródłowych potoków Skawicy Sołtysiej w kierunku Lasu Suwark, 665-695 m n.p.m., $49^{\circ} 38^{\prime} 35^{\prime \prime} \mathrm{N}, 1^{\circ} 35^{\prime} 20^{\prime \prime} \mathrm{E}$, na kamieniu piaskowcowym w lesie świerkowym, ATMOS Gd-17, 6.10.2017, Ochyra \& Klama 1669/17 (KRAM B-243920); (3) Podpolice, 2 km na południe od Zawoi Fujacy, na północ od nowego mostu na Skawicy Górnej, 600-615 m n.p.m., 49³8'35"N, 19³5'36"E, na wilgotnych blokach piaskowcowych na lewym brzegu potoku w towarzystwie Ctenidium molluscum (Hedw.) Mitt., ATMOS Gd-17, 5.10.2017, Ochyra \& Klama 1731/17 (KRAM B-243868); (4) to samo stanowisko, na mokrym głazie w korycie potoku, 5.10.2017, Ochyra \& Klama 1610/17 (KRAM B-243858); (5) to samo stanowisko, na wilgotnym głazie piaskowcowym na stromym zboczu nad potokiem w lesie świerkowym, w darni Plagiomnium undulatum (Hedw.) T.J.Kop., 5.10.2017, Ochyra \& Klama 1617/17 (KRAM B-243866).

Schistidium trichodon jest gatunkiem górskim, ale jego rozmieszczenie w Polsce nie jest dobrze poznane. Do tej pory gatunek ten znany jest z Bieszczadów Zachodnich w polskich Karpatach Wschodnich (BLOM 1996) oraz z Tatr, Małych Pienin i Pienin (BLOM 1996; OChyRA \& Stebel 2008; STEBel i in. 2010) (Ryc. 6C). W Beskidach Zachodnich gatunek ten był dotychczas stwierdzony tylko jeden raz w Beskidzie Śląskim, gdzie występuje tylko w osobnej odmianie - var. nutans H.H.Blom (PLÁŠEK \& STEBEL 2002), która jest u nas znana 

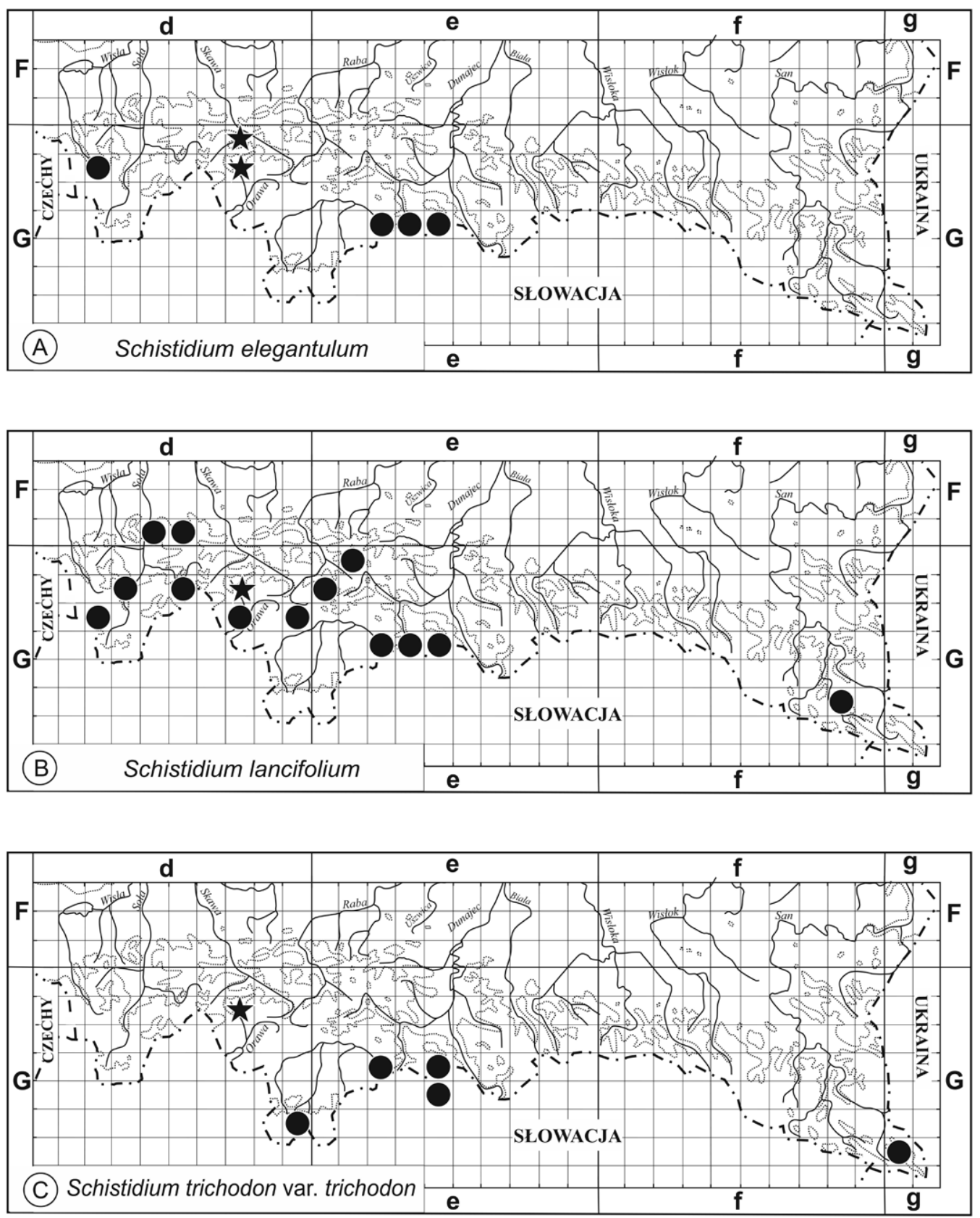

Ryc. 6. Aktualne rozmieszczenie geograficzne wybranych gatunków mchów w polskich Karpatach. Stanowiska w Paśmie Policy zaznaczone gwiazdką

Fig. 6. Current geographical distribution of selected moss species in the Polish Carpathians. Localities in the Polica Range marked with an asterisk

Schistidium elegantulum (A), S. lancifolium (B), S. trichodon var. trichodon (C) 
także z Tatr, Małych Pienin i Pojezierza Mazurskiego (BLOM 1996), natomiast populacje z Pasma Policy reprezentują odmianę-typ tego gatunku i jest ona podana po raz pierwszy z Beskidów Zachodnich. Jest ona rośliną większą, o prostych i często czarnych łodyżkach na szczycie, mającą wydłużoną cylindryczną puszkę, która jest 1,6-2,4 razy dłuższa niż szeroka (u var. nutans jest ona krótsza, często kubkowata, 1,3-2,1 razy dłuższa niż szeroka). Gatunek ten rośnie w dużej obfitości na wszystkich stanowiskach, co może wskazywać, że nie jest on mchem rzadkim w innych pasmach zachodniobeskidzkich.

Dilutineuron fasciculare (Hedw.) Bedn.-Ochyra, Sawicki, Ochyra, Szczecińska \& Plášek

Na północnych stokach głównego grzbietu poniżej Przełęczy Kucałowej przy szlaku do Skawicy Suchej Góry, 1068 m n.p.m., 49 $37^{\prime} 53^{\prime \prime} \mathrm{N}, 1^{\circ} 39^{\prime} 15^{\prime \prime} \mathrm{E}$, na suchym ocienionym głazie piaskowcowym w lesie bukowym, ATMOS Gd-17, 6.07.2017, Ochyra \& Klama 200/17 (KRAM B-240799).

Dilutineuron fasciculare jest dość częstym w Polsce, górskim gatunkiem naskalnego mchu, występującym pospolicie w niektórych pasmach Sudetów oraz w Tatrach (OcHYRA i in. 1990a; BeDnareK-OChYRA 1995). Poza Tatrami w innych częściach polskich Karpat występuje bardzo rzadko (Ryc. 8A) i dotychczas znany jest z kilku stanowisk w Beskidzie Śląskim, na jednym stanowisku na Pilsku w Beskidzie Wysokim oraz na jednym stanowisku w Gorcach (Ochyra i in. 1990; Bednarek-Ochyra 1995; Stebel \& BednareK-Ochyra 2004). Poza tym podany był z masywu Babiej Góry w Beskidzie Wysokim (Limpricht 1890), chociaż jest rzeczą interesującą, że Limpricht (1874) nie wymienia tego gatunku we wcześniejszej notatce o mszakach zebranych przez siebie na Babiej Górze. Doniesienia tego nie potwierdzają żadne materiały zielnikowe i chociaż występowanie $D$. fasciculare w tym masywie jest prawdopodobne, to jednak gatunek ten nigdy później nie został znaleziony na Babiej Górze. Nowe stanowisko w Paśmie Policy (BednAReK-Ochyra \& KLAMA - W: Ellis i in. 2019b) jest więc drugim znaleziskiem D. fasciculare w Beskidzie Wysokim, potwierdzonym przez okazy zielnikowe.

*Bucklandiella affinis (F.Weber \& D.Mohr) Bedn.-Ochyra \& Ochyra

(Ryc. 7B)

Na południowy-zachód od przysiółka Kowalowa w Podpolicach, $5 \mathrm{~km}$ na południe od Zawoi Fujacy, w obszarze źródliskowym jednego z orograficznie lewych dopływów Skawicy Górnej, 690-765 m n.p.m., $49^{\circ} 38^{\prime} 10^{\prime \prime} \mathrm{N}, 19^{\circ} 35^{\prime} 51^{\prime \prime} \mathrm{E}$, na suchym piaskowcowym głazie w lesie świerkowym, ATMOS Gd-17, 5.10.2017, Ochyra \& Klama 1480/17 (KRAM B-243719).

Niezwykle rzadki w polskich Karpatach borealno-górski gatunek, znany dotychczas tylko z jednego stanowiska na Pogórzu Rożnowskim (SZAFRAn 1956 jako Racomitrium heterostichum (Hedw.) Brid.; BedNAREK-OchYRA i in. 1990a; BEDNAREK-OCHYRA 1995) (Ryc. 8B). Jego nowo odkryte stanowisko w Paśmie Policy (BeDnAReK-OchYRA \& KLAMA - W: Ellis $\mathrm{i}$ in. 2019b) jest więc pierwszym znaleziskiem tego gatunku w polskich Karpatach po ponad 70 latach (pierwsze znalezisko tego gatunku na Pogórzu Rożnowskim pochodzi z 1946 r.). Bucklandiella affinis jest w Polsce rzadkim gatunkiem, znanym głównie z rozproszonych stanowisk w Sudetach oraz kilku reliktowych stanowisk na Pomorzu Zachodnim oraz Pojezierzu Olsztyńskim, z których większość datuje się z XIX i pierwszej połowy XX w. (BEDNAREKOCHYRA $i$ in. 1990a; BEDNAREK-OCHYRA 1995). 

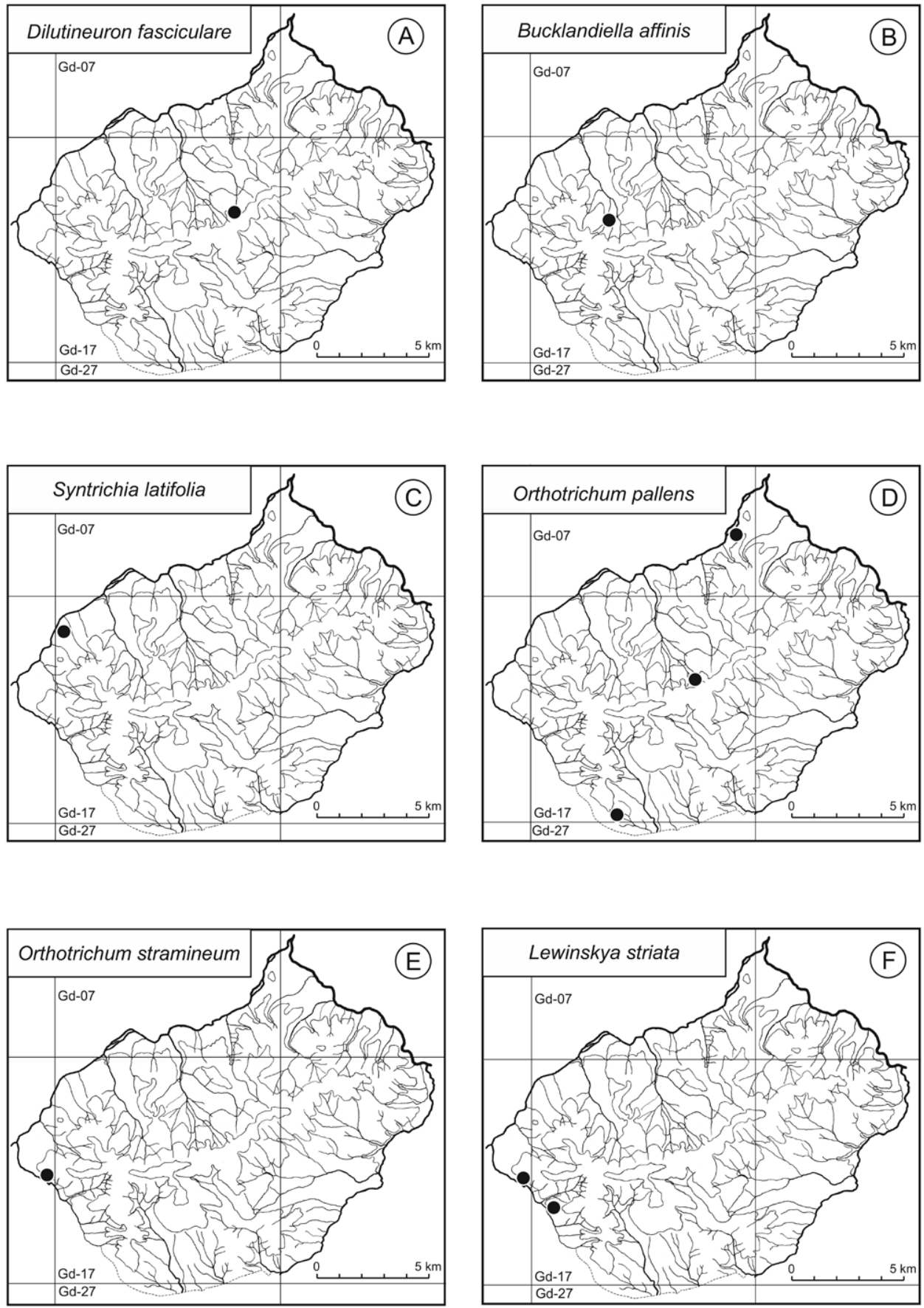

Ryc. 7. Rozmieszczenie gatunków mchów nowych dla Pasma Policy

Fig. 7. Distribution of moss species new to the Polica Range

Dilutineuron fasciculare (A), Bucklandiella affinis (B), Syntrichia latifolia (C), Orthotrichum pallens (D), O. stramineum (E), Lewinskya striata $(\mathrm{F})$ 

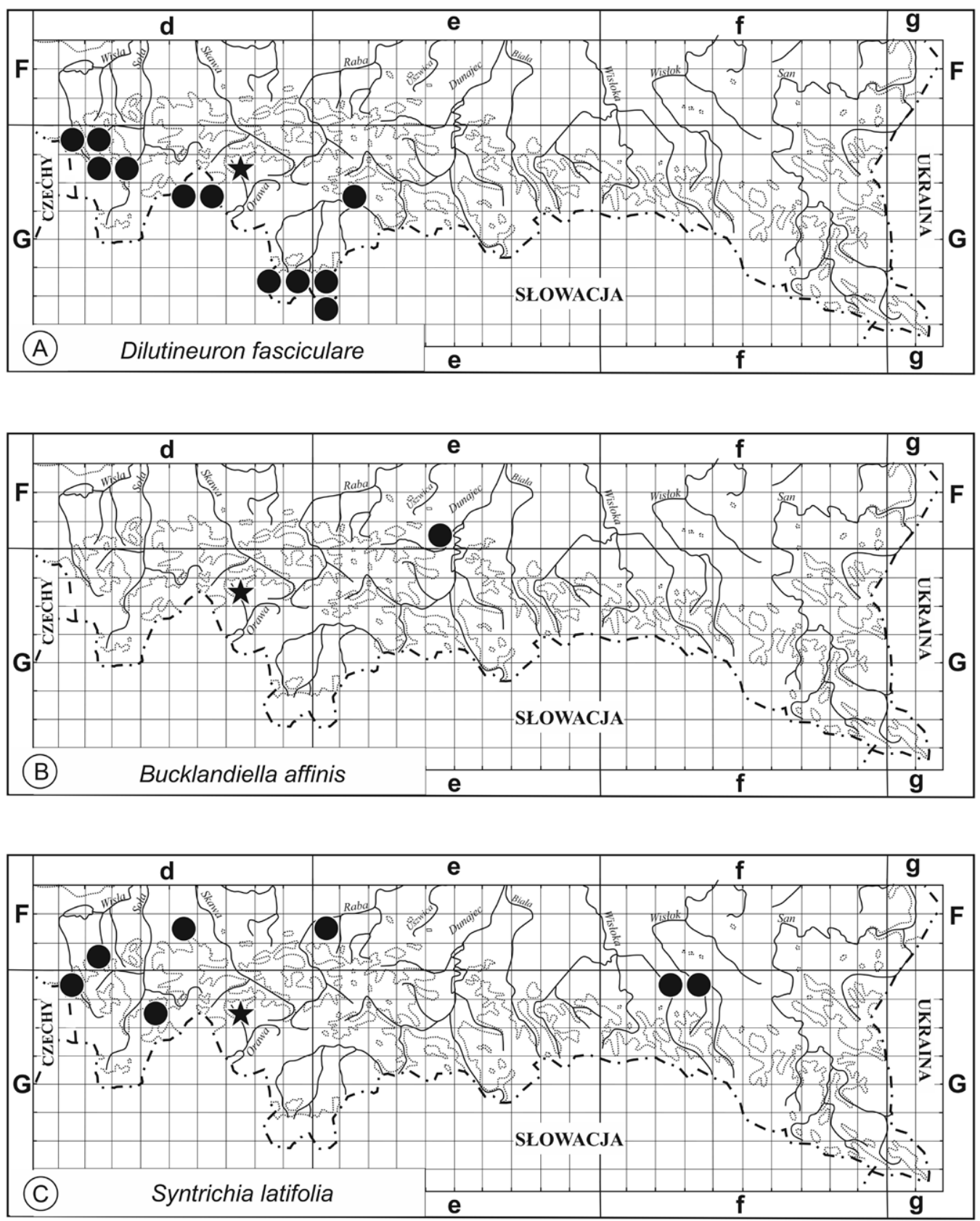

Ryc. 8. Aktualne rozmieszczenie geograficzne wybranych gatunków mchów w polskich Karpatach. Stanowiska w Paśmie Policy zaznaczone gwiazdką

Fig. 8. Current geographical distribution of selected moss species in the Polish Carpathians. Localities in the Polica Range marked with an asterisk

Dilutineuron fasciculare (A), Bucklandiella affinis (B), Syntrichia latifolia (C) 


\section{Pottiaceae Hampe}

Syntrichia latifolia (Hartm.) Huebener

(Ryc. 7C)

Zawoja Centrum, 536 m n.p.m., 49³9'39,9'N, 19³3'35,6"E, ocieniony mur obok kościoła, ATMOS Gd-17, 14.06.2019, Stebel s.n. (KRAM B-248060, SOSN).

Syntrichia latifolia jest rzadkim gatunkiem epifitycznym, rosnącym w dużym rozproszeniu na korze drzew liściastych, sporadycznie zasiedlający także podłoża skalne (Ryc. 9, 10) na niżu i przedpolu Karpat i Sudetów, ale w górach bardzo rzadki. W Karpatach znany jest tylko z Dołów Jasielsko-Sanockich (ARMATA 2006, 2011), Pogórza Śląskiego (STEBEL 2004a; STEBel \& KRAJEWSKi 2020) oraz Beskidu Śląskiego i Kotliny Żywieckiej (PláŠEK \& STEBEL 2002; STEBel 2008, 2009) i teraz znaleziony został w Paśmie Policy (Ryc. 8C).

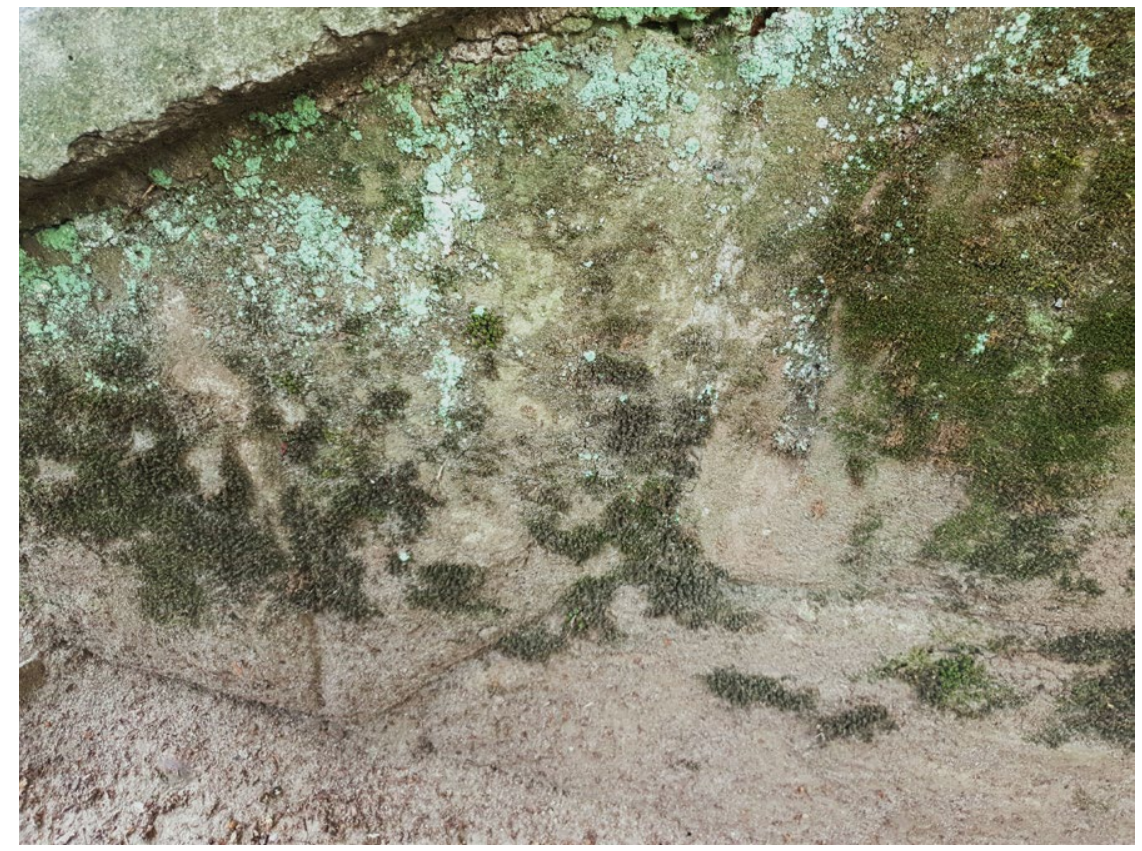

Ryc. 9. Płaty Syntrichia latifolia na murze kościoła w Zawoi Centrum (fot. A. Stebel, 10.08.2019)

Fig. 9. Patches of Syntrichia latifolia on the stone wall at the church in Zawoja Centrum (photo by A. Stebel, 10.08.2019)

\section{Orthotrichaceae Arn.}

Orthotrichum pallens Brid.

(Ryc. 7D)

(1) Białka, 400-470 m n.p.m., 49 41'24"N, 1940'20'E, na korze pnia Salix fragilis przy głównej drodze, ATMOS Gd-07, 7.09.1978, Ochyra 924/78 (KRAM B-214327); (2) na południowy-zachód od klifu Łysina przy trakcie leśnym na północnych stokach głównego grzbietu pasma poniżej Złotej Grapy, 1050 m n.p.m., 49 $37^{\prime} 47^{\prime \prime} \mathrm{N}, 19^{\circ} 38^{\prime} 12^{\prime \prime} \mathrm{E}$, na korze pnia starego buka, ATMOS Gd-17, 6.07.2017, Ochyra \& Klama 267/17 (KRAM B-240896); (3) Ochlipów, wzdłuż drogi w kierunku Krowiarek, 955 m n.p.m., betonowa bariera ochronna obok drogi, ATMOS Gd-17, 27.08.1999, Stebel s.n., det. V. Plášek, 2005 (SOSN-29756). 


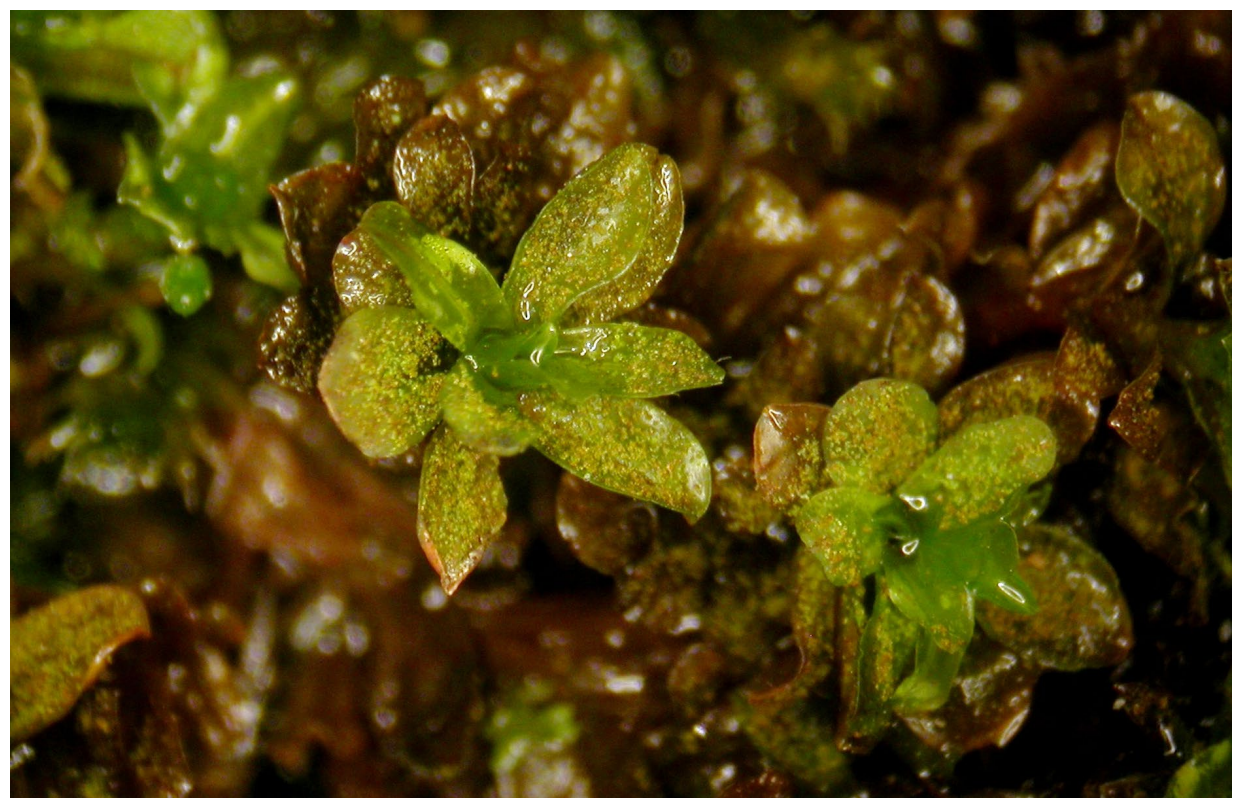

Ryc. 10. Syntrichia latifolia z rozmnóżkami (fot. V. Plášek)

Fig. 10. Syntrichia latifolia with gemmae (photo by V. Plášek)

W Beskidach Zachodnich Orthotrichum pallens (Ryc. 11) jest bardzo rzadkim epifitycznym gatunkiem, występującym na rozproszonych stanowiskach w Beskidzie Śląskim, Beskidzie Małym, Beskidzie Makowskim, Beskidzie Wysokim i Beskidzie Wyspowym (Stebel 2006a, 2010a, 2017), na Pogórzu Orawsko-Jordanowskim (STEBel \& VončinA 2014) oraz Beskidzie Sądeckim (STEBel 2015a) i Beskidzie Niskim (STEBel 2011). Poza tymi górami, gatunek ten występuje często w Pieninach (STEBEL i in. 2010) oraz bardzo rzadko w Skalicach Nowotarskich i Spiskich (OchYRA 1984), Małych Pieninach (OchYRA \& Stebel 2008) i Tatrach (ChaŁubińsKi 1886). Ponadto jest bardzo rzadkim gatunkiem na Pogórzu Cieszyńskim (WiLCzeK 1936), Pogórzu Rożnowskim (Szafran 1956) i Pogórzu Wielickim (ŻMUDA 1912).

Orthotrichum stramineum Brid.

(Ryc. 7E)

Zawoja Policzne, 705 m n.p.m., 49³6'49,8'N, 19³3'04,1"E, na korze przydrożnej Salix caprea, ATMOS Gd-16, 14.06.2019, Stebel s.n. (KRAM B-248064, SOSN).

Bardzo rzadki epifityczny gatunek (Ryc. 12), występujący we wszystkich pasmach Beskidów Zachodnich, od Beskidu Śląskiego na zachodzie po Beskid Niski na wschodzie (WaCŁawska 1957; Stebel 2006a, 2011, 2015a, 2017; Stebel \& VončIna 2014). Poza tym dość często występuje w Pieninach (STEBel i in. 2010) i Małych Pieninach (Ochyra \& STEBeL 2008) oraz bardzo rzadko w Tatrach (ChAŁubiński 1886; OchYRA \& CisŁo 1999). Orthotrichum stramineum występuje również rzadko w Górach Sanocko-Turczańskich (STEBEL i in. 2016) i Bieszczadach Zachodnich (STEBEL \& ŻARNOwIEC 2010; ŻARNOwIEC \& STEBEL 2016) w polskich Karpatach Wschodnich. 


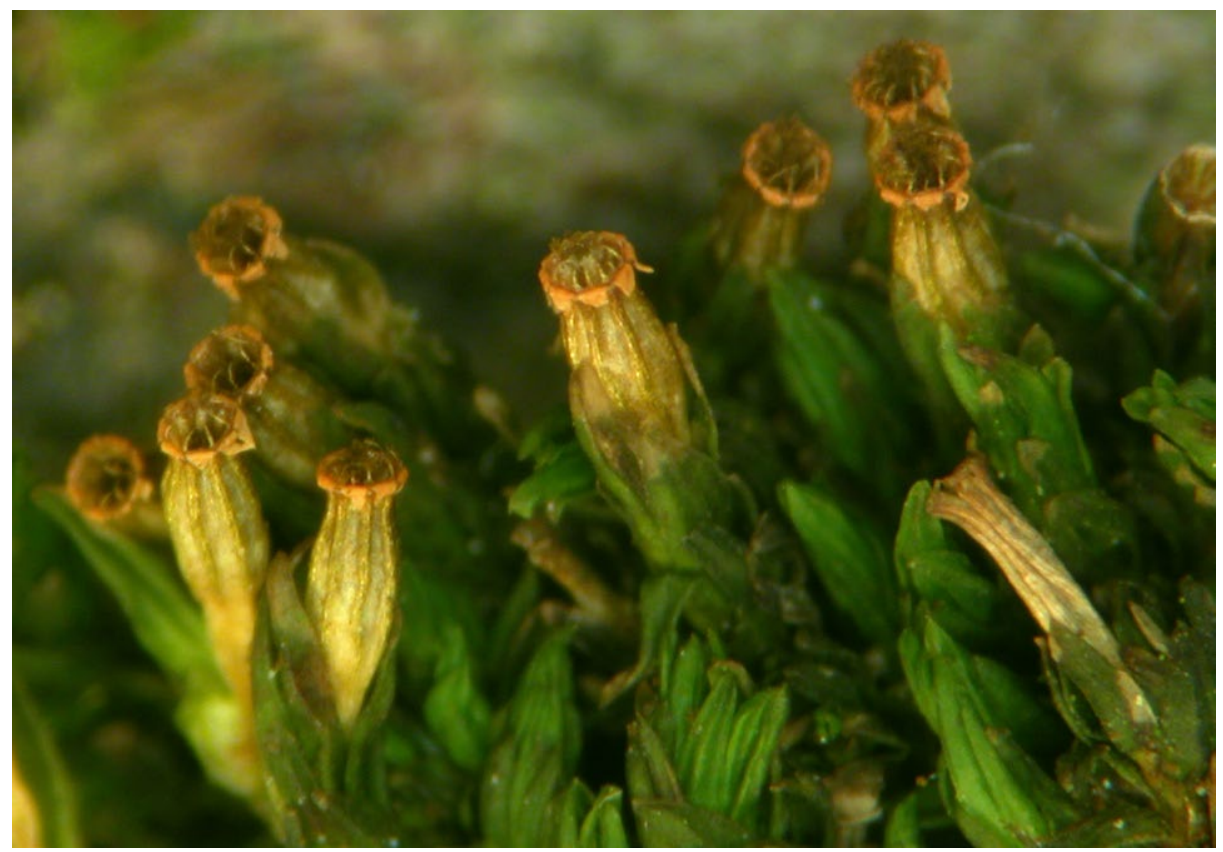

Ryc. 11. Orthotrichum pallens (fot. V. Plášek)

Fig. 11. Orthotrichum pallens (photo by V. Plášek)

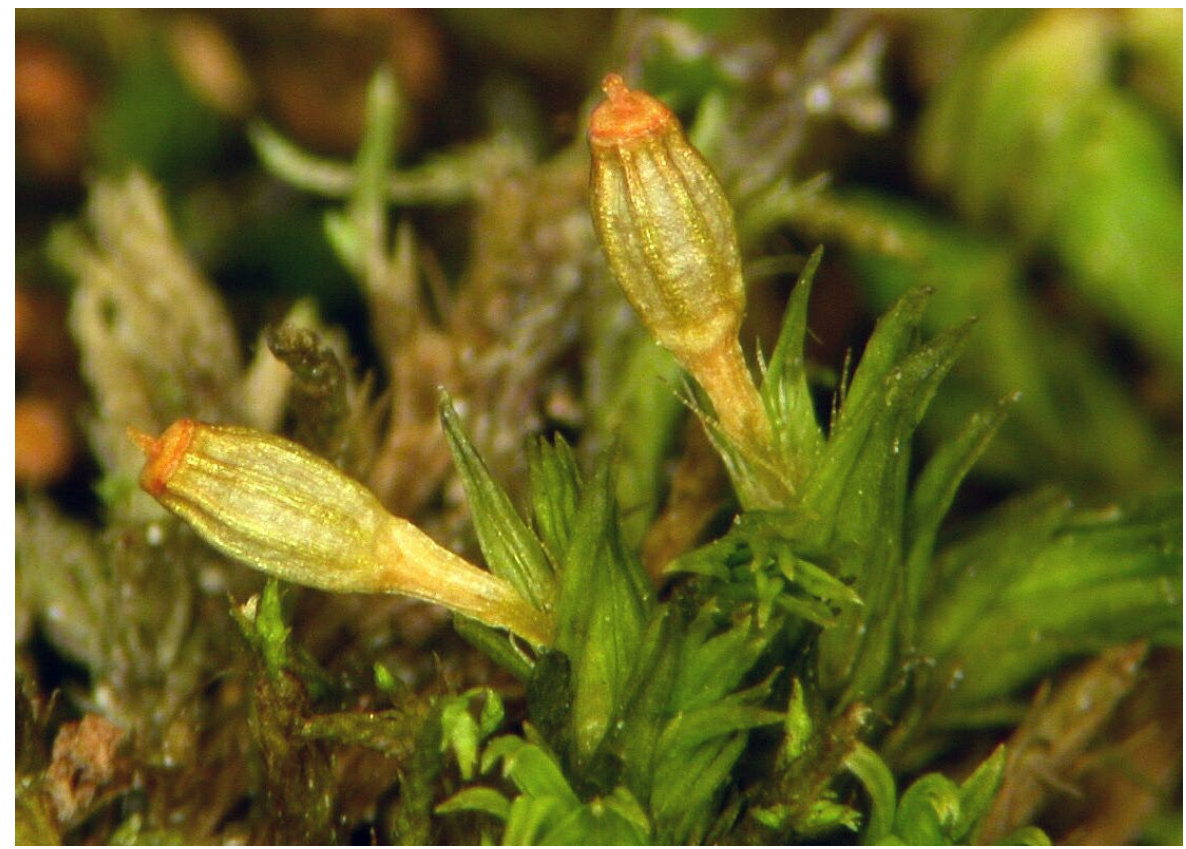

Ryc. 12. Orthotrichum stramineum (fot. V. Plášek)

Fig. 12. Orthotrichum stramineum (photo by V. Plášek) 
Lewinskya striata (Hedw.) F.Lara, Garilleti \& Goffinet (三 Orthotrichum striatum Hedw.) (Ryc. 7F)

(1) Zawoja Policzne, 705 m n.p.m., 49 $36^{\prime} 49,8^{\prime \prime} \mathrm{N}, 1^{\circ} 33^{\prime} 04,1^{\prime \prime} \mathrm{E}$, na korze przydrożnej Salix caprea, ATMOS Gd-16, 14.06.2019, Stebel s.n. (KRAM B-248063); (2) Zawoja, dolina potoku Jaworzyna, 746 m n.p.m., 49 36'24,2"N, 19³3'41,2"E, na korze przydrożnego Fagus sylvatica obok drogi Zawoja - Zubrzyca, ATMOS Gd-17, 10.08.2019, Stebel s.n. (KRAM B-249907).

Bardzo rzadki epifityczny gatunek (Ryc. 13), rosnący na korze drzew liściastych, stwierdzony w kilku pasmach zachodniobeskidzkich (Beskid Śląski, Beskid Mały, Beskid Wysoki, Gorce, Pogórze Orawsko-Jordanowskie, Beskid Sądecki, Beskid Niski) (WacŁaWskA 1957; MamcZarz 1977; KarcZmarz 1987; Stebel 2006a, 2017; Stebel \& VonČIna 2014)

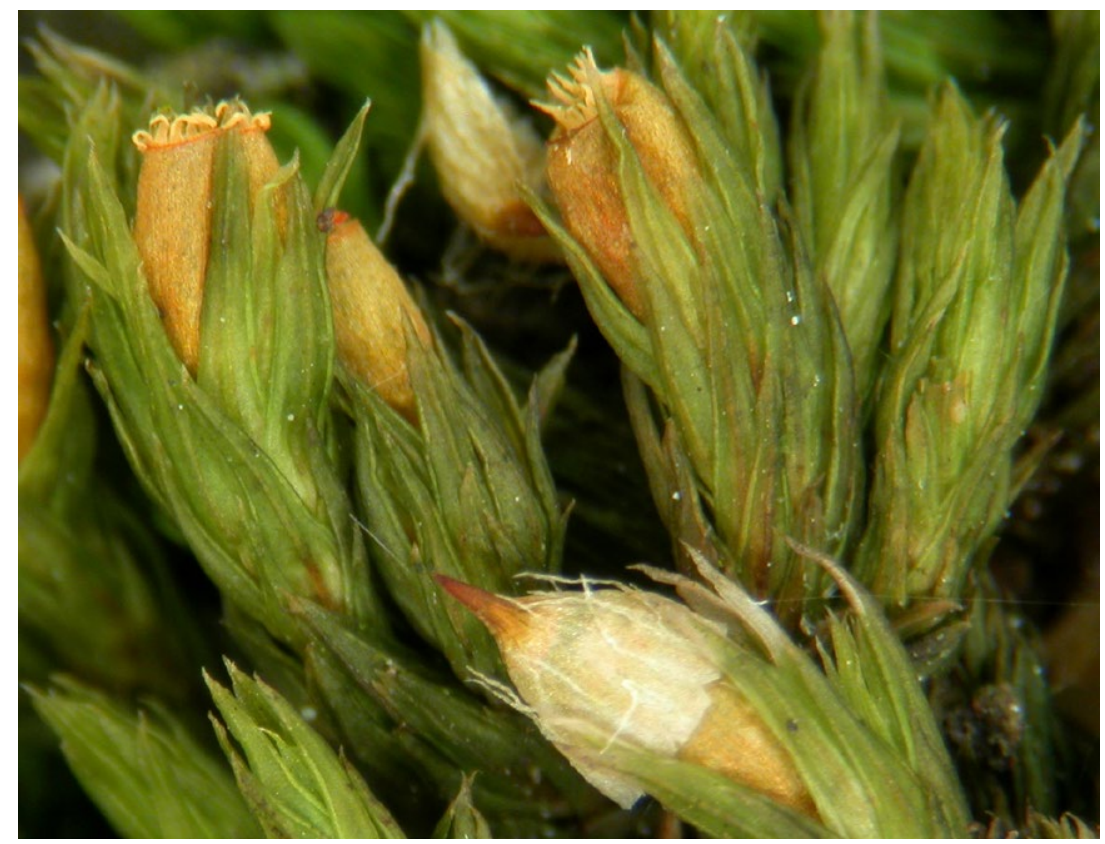

Ryc. 13. Lewinskya striata (fot. V. Plášek)

Fig. 13. Lewinskya striata (photo by V. Plášek)

i teraz w Paśmie Policy. Prócz tego występuje dość rzadko w Małych Pieninach (OchYRA \& Stebel 2010), Pieninach (Stebel i in. 2010) i Tatrach (Chalubiński 1886; Ochyra \& CisŁo 1999) oraz na Pogórzu Ciężkowickim (STEBel \& VonČINA 2017).

Zygodon dentatus (Limpr.) Kartt.

(Ryc. 14A)

Zawoja Widły, 720-750 m n.p.m., 49 37'44"N, 19³2'20"E, na korze pnia Salix fragilis, ATMOS Gd-16, 28.07.1978, Ochyra 2206/78 (KRAM B-224959).

Bardzo rzadki gatunek epifityczny (Ryc. 15), występujący w Polsce prawie wyłącznie w Karpatach (Ryc. 16A), podczas gdy w Sudetach był stwierdzony tylko jeden raz 

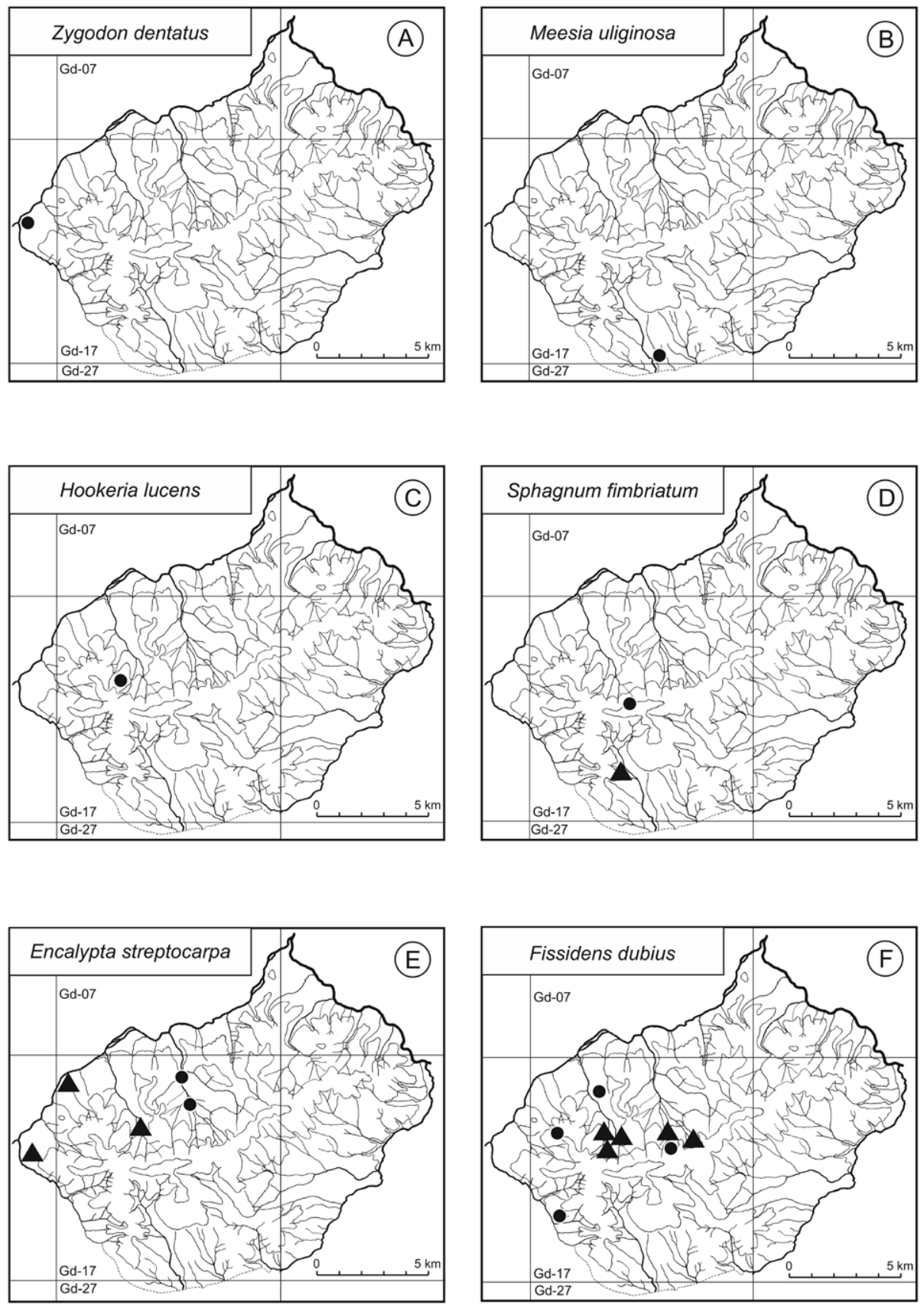

Ryc. 14. Rozmieszczenie nowych oraz bardzo rzadkich i rzadkich gatunków mchów w Paśmie Policy. Nowe stanowiska bardzo rzadkich i rzadkich gatunków oznaczone są trójkątami

Fig. 14. Distribution of new and very rare and rare moss species in the Polica Range. New localities are marked with triangles

Zygodon dentatus (A), Meesia uliginosa (B), Hookeria lucens (C), Sphagnum fimbriatum (D), Encalypta streptocarpa (E), Fissidens dubius $(\mathrm{F})$ 


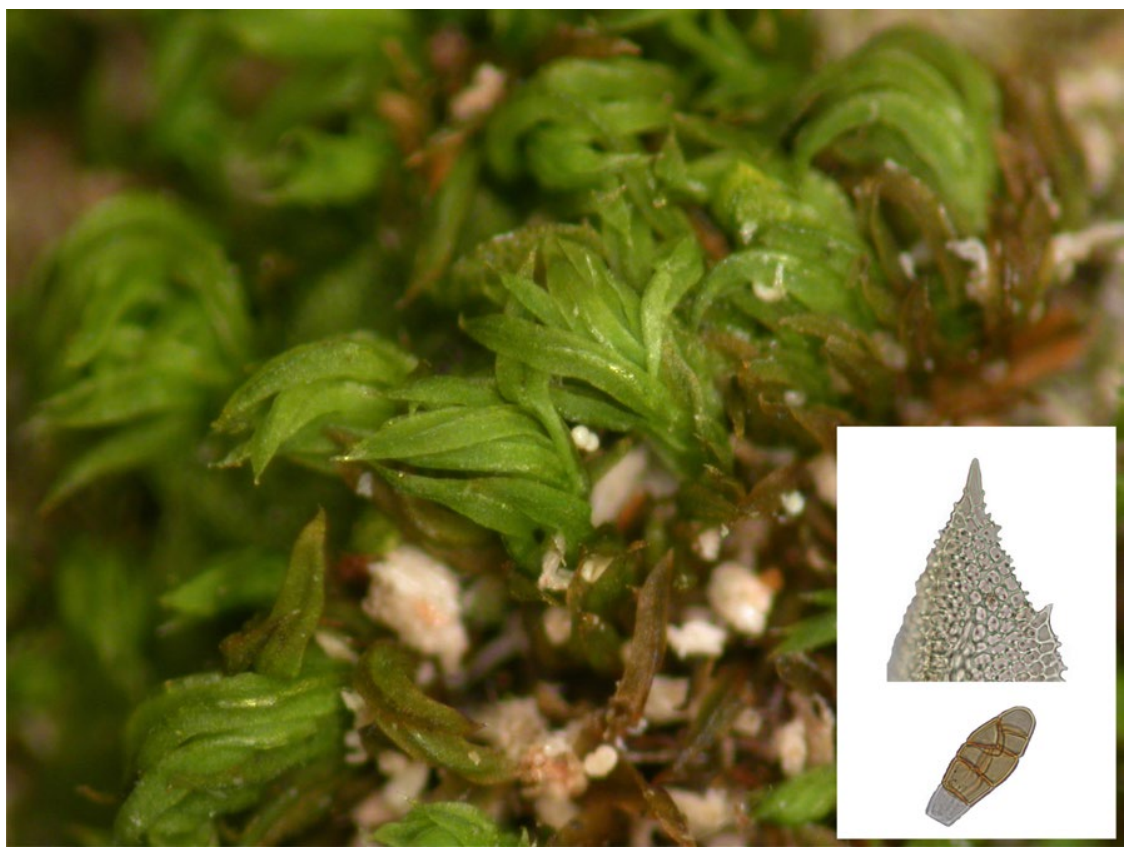

Ryc. 15. Zygodon dentatus (fot. V. Plášek)

Fig. 15. Zygodon dentatus (photo by V. Plášek)

w Górach Bialskich (STEBEL \& ŻARnOwIEC 2017). W polskich Karpatach Zachodnich występuje najczęściej w Beskidach Zachodnich, gdzie rośnie bardzo rzadko i w dużym rozproszeniu w większości pasm górskich, chociaż najwięcej notowań pochodzi z Beskidu Wysokiego i Gorców. Bardzo rzadko występuje również w Tatrach (STEBEL \& ŻARNOwIEC 2017) i Pienińskim Pasie Skałkowym (VončIna 2019). W Paśmie Policy niewielka populacja Zygodon dentatus została znaleziona na korze wierzby w dolnej części regla dolnego. W polskich Karpatach gatunek ten wykazuje sporą przerwę zasięgową w Beskidzie Niskim i przyległych doń partiach Pogórza Środkowobeskidzkiego, po której pojawia się znowu w Karpatach Wschodnich (Góry Sanocko-Turczańskie, Bieszczady Zachodnie) (STEBEL \& ŻARNOWIEC 2017).

\section{Meesiaceae Schimp.}

Meesia uliginosa Hedw.

(Ryc. 14B)

Ochlipów, $3 \mathrm{~km}$ na północny-zachód od Zubrzycy Górnej, 860 m n.p.m., 49³5'13"N, 19³6'48"E, na mokrej glebie w rowie na torfowisku, ATMOS Gd-17, 28.07.1978, Ochyra 2561/78 (KRAM B-225772).

Meesia uliginosa występuje pospolicie w wyższych położeniach w wapiennych Tatrach Zachodnich oraz na zmylonityzowanych skałach granitowych w Tatrach Wysokich (OcHYRA $\mathrm{i}$ in. 1988a). Poza Tatrami gatunek ten był znaleziony tylko jeden raz w polskich Karpatach w Gorcach (Lisowski \& KoRnAś 1966). Obecne znalezisko w Paśmie Policy jest więc drugim stanowiskiem tego gatunku w Beskidach Zachodnich (Ryc. 16B). 

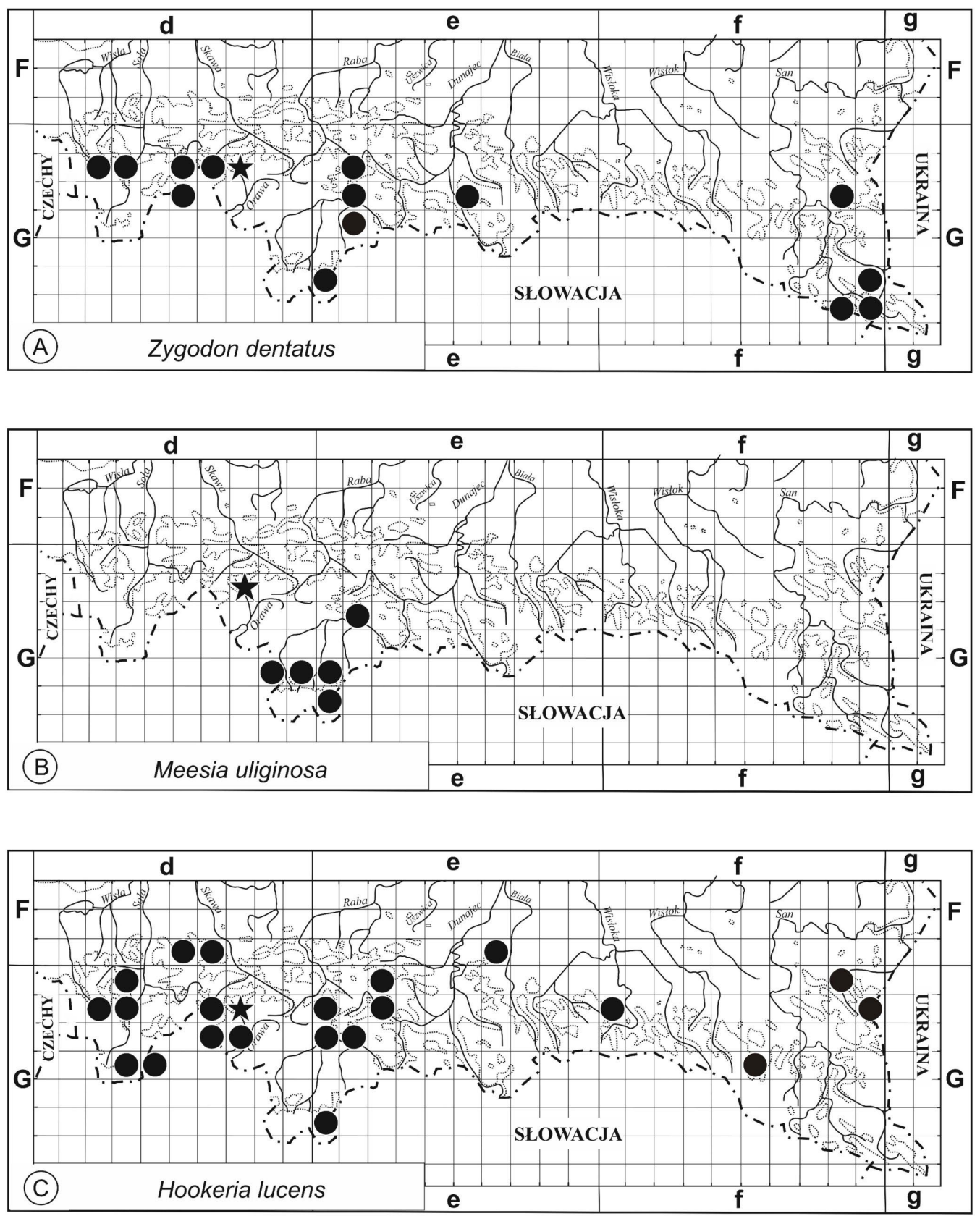

Ryc. 16. Aktualne rozmieszczenie geograficzne wybranych gatunków mchów w polskich Karpatach. Stanowiska w Paśmie Policy zaznaczone gwiazdką

Fig. 16. Current geographical distribution of selected moss species in the Polish Carpathians. Localities in the Polica Range marked with an asterisk

Zygodon dentatus (A), Meesia uliginosa (B), Hookeria lucens (C) 


\section{Hookeriaceae Schimp.}

Hookeria lucens (Hedw.) Sm.

(Ryc. 14C)

Na południowy-zachód od przysiółka Kowalowa w Podpolicach, około 5 km na południe od Zawoi Fujacy, w obszarze źródliskowym jednego z orograficznie lewych dopływów Skawicy Sołtysiej, 788 m n.p.m., $49^{\circ} 38^{\prime} 6^{\prime \prime} \mathrm{N}, 19^{\circ} 35^{\prime} 51^{\prime \prime} \mathrm{E}$, na wilgotnych i zacienionych głazach i blokach piaskowcowych na zboczu doliny w borze świerkowym z domieszką starych okazów Fagus sylvatica w drzewostanie, ATMOS Gd-17, notowanie Ochyra \& Klama, 5.10.2017.

Ten bardzo rzadki i zagrożony gatunek mchu (Ryc. 17) (ŻARNOwIEC i in. 2004), znajdujący się pod ścisłą ochroną (ANONIM 2014), został po wielu latach specjalnych poszukiwań odnaleziony na jednym stanowisku w Paśmie Policy. To cenne znalezisko we florze mchów tego pasma zostało szczegółowo opisane w osobnej publikacji (KLAMA \& OCHYRA 2018).

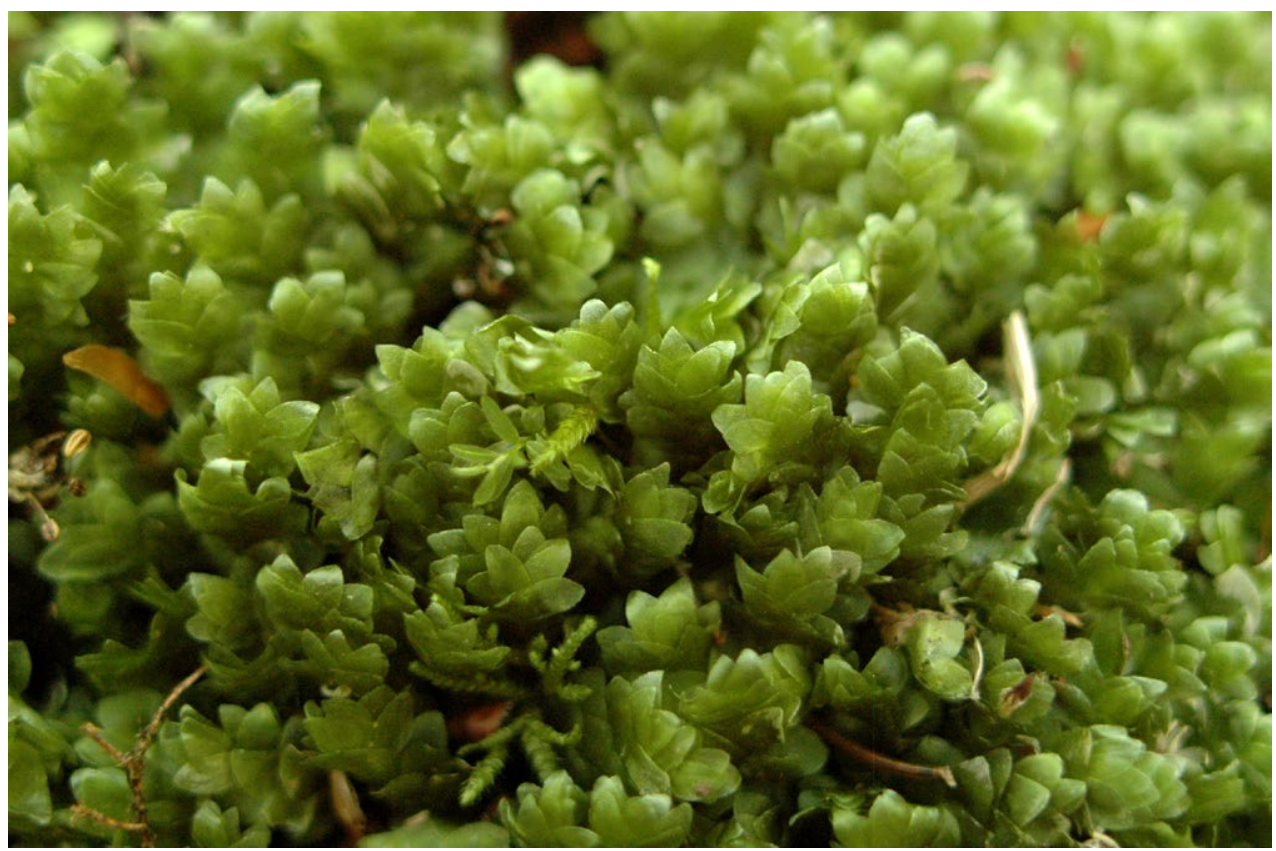

Ryc. 17. Hookeria lucens (fot. V. Plášek)

Fig. 17. Hookeria lucens (photo by V. Plášek)

Od czasu opracowania rozmieszczenia Hookeria lucens w polskiej części Karpat (STEBEL i in. 2004) kolejne stanowiska tego gatunku zostały odnalezione w Beskidzie Małym (BARĆ i in. 2007), Beskidzie Wysokim (Stebel \& KraJeWSKi 2020), Gorcach (PACioreK 2015; STEBel i in. 2017), Beskidzie Niskim (VoNČINA 2015; npbl. stanowisko w rezerwacie „Kamień nad Rzepedzią”, znalezione przez M. Szczepańskiego) i na Pogórzu Przemyskim (npbl. stanowisko w dawnej osadzie leśnej Trójca znalezione przez D. Bury, informacja listowna z dnia 22 grudnia 2019 r. i 20 czerwca 2020 r.) oraz w projektowanym Turnickim Parku Narodowym w Górach Sanocko-Turczańskich w Beskidach Wschodnich (BuRY 2018) (Ryc. 16C). 


\title{
Nowe stanowiska rzadkich gatunków we florze mchów Pasma Policy
}

\author{
Sphagnaceae Dumort.
}

Sphagnum fimbriatum Wilson

(Ryc. 14D)

Ochlipów między Przełęczą Krowiarki i Zubrzycą Górną w południowej części doliny Białego Potoku, między Polaną Knopówki i Polaną Nowiny, u południowego podnóża Policy, 909 m n.p.m., 49³5'57"N, $19^{\circ} 36^{\prime} 44^{\prime \prime} \mathrm{E}$, w wilgotnym i zacienionym zagłębieniu w lesie świerkowym, ATMOS Gd-17, 7.07.2017, Ochyra \& Klama 87/17 (KRAM B-240496).

Sphagnum fimbriatum jest obok S. compactum Lam. \& DC., najrzadszym gatunkiem torfowca w Pasmie Policy, znanym tylko z jednego stanowiska w szczytowych partiach pasma. Nowe stanowisko tego gatunku zostało znalezione w reglu dolnym w wilgotnym lesie świerkowym. Podobnie jak na badanym terenie, gatunek ten jest bardzo rzadki w innych pasmach zachodniobeskidzkich (Beskid Śląski, Beskid Wysoki, Beskid Wyspowy, Gorce, Beskid Niski) (Karczmarz 1987; Stebel 2006a; Stebel i in. 2016) i tylko w Beskidzie Małym występuje nieco liczniej na pięciu stanowiskach (STEBEL 2010a). Poza tym jest bardzo rzadki w Pieninach (Stebel i in. 2010) i Małych Pieninach (VonČInA \& STEBEl 2016), ale jak dotąd nie był notowany w Tatrach (OCHYRA \& CisŁo 1999; LISOWSKI 1959, 1965).

\section{Encalyptaceae Schimp.}

Encalypta streptocarpa Hedw.

(Ryc. 14E, 18)

(1) Podpolice 2,5 km na południe od Zawoi Fujacy, nowy most na Skawicy Górnej, 615 m n.p.m., $49^{\circ} 38^{\prime} 05^{\prime \prime} \mathrm{N}, 19^{\circ} 35^{\prime} 38^{\prime \prime} \mathrm{E}$, na kamiennym filarze mostu, ATMOS Gd-17, 7.07.2017, Ochyra \& Klama 411/17 (KRAM B-243985); (2) Zawoja Centrum, 535 m n.p.m., 49³9'39,6"N, 19³3'35,8"E, ocieniony mur obok kościoła, ATMOS Gd-17, 14.06.2019, Stebel s.n. (KRAM B-248061, SOSN); (3) Zawoja, dolina potoku Jaworzyna, $656 \mathrm{~m}$ n.p.m., $49^{\circ} 37^{\prime} 22,0^{\prime \prime} \mathrm{N}, 1^{\circ} 32^{\prime} 19,1^{\prime \prime} \mathrm{E}$, na starym kamiennym murze nad brzegiem Jaworzyny naprzeciw ujścia Rybnego Potoku, ATMOS Gd-16, 10.08.2019, Stebel s.n. (KRAM B-249905).

Bardzo rzadki gatunek, znany dotąd tylko z dwóch nisko położonych stanowisk w dolnych partiach regla dolnego (Ryc. 18). Oba nowe stanowiska znajdują się na podobnych wysokościach, a jedno z nich leży już w piętrze pogórza. W innych pasmach zachodniobeskidzkich Encalypta streptocarpa jest częstym gatunkiem (Beskid Śląski, Beskid Mały) lub dość częstym (Kotlina Żywiecka, Beskid Wyspowy, Beskid Wysoki) i tylko na Pogórzu Orawsko-Jordanowskim zwanym również Działami Orawskimi (STEBeL \& VonČina 2014) oraz w Beskidzie Makowskim i Gorcach jest, podobnie jak w Paśmie Policy, bardzo rzadkim gatunkiem (STEBEL 2006a), chociaż ostatnio został on znaleziony na jeszcze jednym stanowisku w Gorcach (STEBEL i in. 2017). Natomiast E. streptocarpa występuje bardzo pospolicie w całym Pienińskim Pasie Skałkowym (OchYra 1984; OchYRA \& STEBel 2008; STEBel i in. 2010), a w Tatrach również należy do częstych gatunków (LISOWSKI 1959; OCHYRA \& CISŁO 1999). 


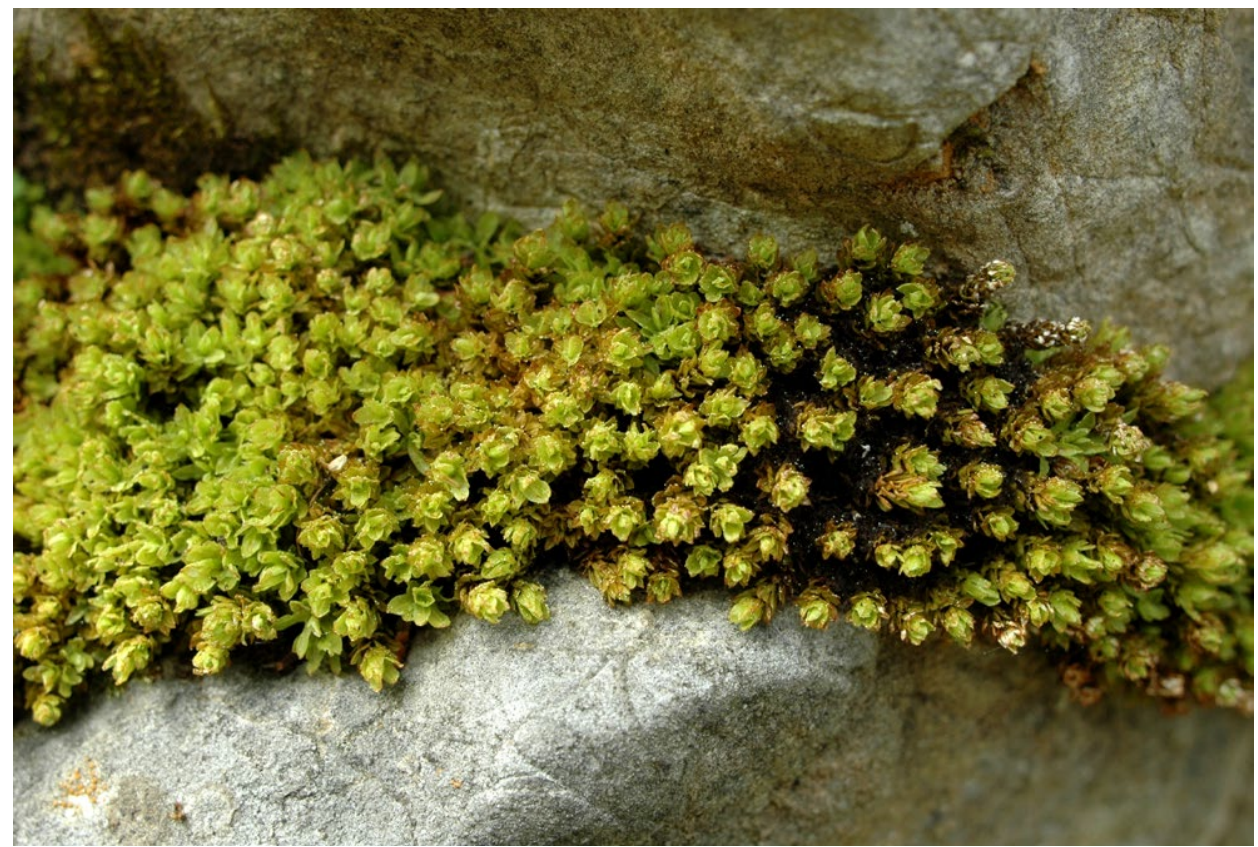

Ryc. 18. Encalypta streptocarpa (fot. V. Plášek)

Fig. 18. Encalypta streptocarpa (photo by V. Plášek)

\section{Fissidentaceae Schimp.}

Fissidens dubius P.Beauv.

(Ryc. 14F)

(1) Okrąglica na wschód od Hali Krupowej w głównym grzbiecie pasma, 1240 m n.p.m., 49³7'38'N, $19^{\circ} 39^{\prime} 19^{\prime \prime} \mathrm{E}$, zacieniony głaz piaskowcowy w wykrocie po powalonym świerku w lesie świerkowym, 6.07.2017, Ochyra \& Klama 176/17 (KRAM B-240747); (2) Skawica Sucha Góra, Sitarka 4 km na południe od Skawicy, wzdłuż jednego ze źródłowych potoków Skawicy Sołtysiej w kierunku Lasu Suwark, 695-705 m n.p.m., 49 $38^{\prime} 26^{\prime \prime} \mathrm{N}, 1^{\circ} 38^{\prime} 17^{\prime \prime} \mathrm{E}$, pod przewieszoną skała piaskowcową razem z Ctenidium molluscum (Hedw.) Mitt. i Apometzgeria pubescens (Schrank) Kuwah. w lesie świerkowym, 6.10.2017, Ochyra \& Klama 1708/17 (KRAM B-243958); (3) Podpolice 2 km na południe od Zawoi Fujacy, na północ od nowego mostu na Skawicy Górnej, 600-615 m n.p.m., 49 38'35"N, 19³5'36"E, na głazie piaskowcowym w lesie świerkowym, ATMOS Gd-17, 5.10.2017, Ochyra \& Klama 1600/17 (KRAM B-243848); (4) na południowy-zachód od przysiółka Kowalowa w Podpolicach, około $5 \mathrm{~km}$ na południe od Zawoi Fujacy, w obszarze źródliskowym jednego z orograficznie lewych dopływów Skawicy Górnej, $788 \mathrm{~m}$ n.p.m., $49^{\circ} 38^{\prime} 6^{\prime \prime} \mathrm{N}, 19^{\circ} 35^{\prime} 51^{\prime \prime} \mathrm{E}$, na ocienionym głazie piaskowcowym w lesie świerkowym razem z Hookeria lucens (Hedw.) Sm., ATMOS Gd-17, 5.10.2017, Ochyra \& Klama 1547/17 (KRAM B-243798); (5) Czarnotowa $4 \mathrm{~km}$ na południe od Zawoi Fujacy, las świerkowy nad Skawicą Górną, $690 \mathrm{~m}$ n.p.m., 49³8'27"N, $19^{\circ} 36^{\prime} 6^{\prime \prime} \mathrm{E}$, na głazie piaskowcowym na brzegu potoku, ATMOS Gd-17, 7.07.2017, Ochyra \& Klama 360/17 (KRAM B-241216).

Fissidens dubius był dotychczas uważany za rzadki naskalny gatunek w Paśmie Policy, znany z zaledwie czterech stanowisk rozproszonych w reglu dolnym w zachodniej części badanego terenu. W trakcie ostatnich badań został on odkryty na dalszych pięciu stanowiskach rozmieszczonych głównie w reglu dolnym, a jedno w reglu górnym, przez co nieoczekiwanie 
gatunek ten należy uznać za dość częsty na tym obszarze. Rośnie on często w szczelinach skalnych i pod przewieszonymi głazami, gdzie może być łatwo przeoczony. Podobnie jest zapewne w innych pasmach zachodniobeskidzkich, gdzie uważany jest za gatunek rzadki lub bardzo rzadki (Stebel 2006a; Stebel \& VonČINA 2014), chociaż ostatnie znaleziska w Gorcach (STEBel i in. 2017) mogą wskazywać, że jest on wszędzie przeoczany (albo być może w ostatnich latach liczba jego stanowisk rośnie), podobnie jak w Paśmie Policy i tylko w Beskidzie Wyspowym jest dość częsty (STEBel 2006a). Bardzo rzadki jest także w Beskidzie Sądeckim (MamcZArz 1977), a w Beskidzie Niskim obok odmiany-typu (STEBEL 2016b), znana jest także jego odmiana $F$. dubius var. mucronatus (Limpr.) Kartt., Hedenäs \& L.Söderstr. (BRYLSKA 1991). Natomiast ten wapieniolubny gatunek występuje pospolicie w Pienińskim Pasie Skałkowym (Ochyra 1984; Ochyra \& Stebel 2008; Stebel i in. 2010), zaś w Tatrach nie należy on do częstych gatunków (LisowsKi 1959; OchYRA \& CisŁo 1999).

\section{Dicranaceae Schimp.}

Cynodontium strumiferum (Hedw.) Lindb.

(Ryc. 19A)

Okrąglica na wschód od Hali Krupowej w głównym grzbiecie pasma, 1240 m n.p.m., 49³7'38"N, 19³9'19"E, na ocienionych głazach piaskowcowych w lesie świerkowym, 6.07.2017, Ochyra \& Klama 173/17 (KRAM B-240744).

Bardzo rzadki gatunek, notowany dotychczas na trzech stanowiskach w Paśmie Policy, od 815 do 1240 m n.p.m. (STEBel $i$ in. 2004). Nowe stanowisko znajduje się również w najwyższych partiach pasma w piętrze regla górnego. Gatunek ten znany jest z wszystkich pasm Beskidów Zachodnich, od Beskidu Śląskiego po Beskid Wyspowy i wszędzie jest gatunkiem bardzo rzadkim (STEBel 2006a). Dotychczas nie był notowany tylko w Kotlinie Żywieckiej (Stebel 2008) oraz w Tatrach (ChaŁubiński 1886; Ochyra \& CisŁo 1999). Ostatnio odnaleziony został w Gorcach (STEBeL i in. 2016, 2017) oraz w Magurskim Parku Narodowym w Beskidzie Niskim (STEBEL 2016b).

\section{Pottiaceae Schimp.}

Didymodon spadiceus (Mitt.) Limpr.

(Ryc. 19B)

Podpolice $2 \mathrm{~km}$ na południe od Zawoi Fujacy, nowy most na Skawicy Górnej, 615 m n.p.m., 49³9'05"N, $19^{\circ} 35^{\prime} 38^{\prime \prime}$ E, na filarze mostu, ATMOS Gd-17, 7.07.2017, Ochyra \& Klama 1723/17 (KRAM B-244275).

Bardzo rzadki gatunek, znany tylko z trzech stanowisk w Paśmie Policy, leżących w piętrze pogórza (STEBEL i in. 2004). Nowo odkryte stanowisko Didymodon spadiceus znajduje się w dolnej partii regla dolnego i odkrycie to zmienia jego dotychczasowy status gatunku bardzo rzadkiego na rzadki pod względem częstości występowania. W większości pasm zachodniobeskidzkich, w których jest znany (Beskid Makowski, Kotlina Żywiecka, Beskid Wyspowy, Beskid Wysoki, Działy Orawskie, Beskid Sądecki, Beskid Niski) jest gatunkiem bardzo rzadkim (WaCŁaWska 1957; MamCZARZ 1977; KarCZMARZ 1987; Stebel 2006a, c; Stebel \& VONČINA 2014) i jedynie w Gorcach ma więcej stanowisk, chociaż nadal jest tu gatunkiem rzadkim (Lisowski \& Kornaś 1966; Stebel 2004a; Stebel i in. 2017). Równie rzadki jest w Tatrach (Lisowski 1959, 1965; Ochyra \& CisŁo 1999), Pieninach (Stebel i in. 2010) 

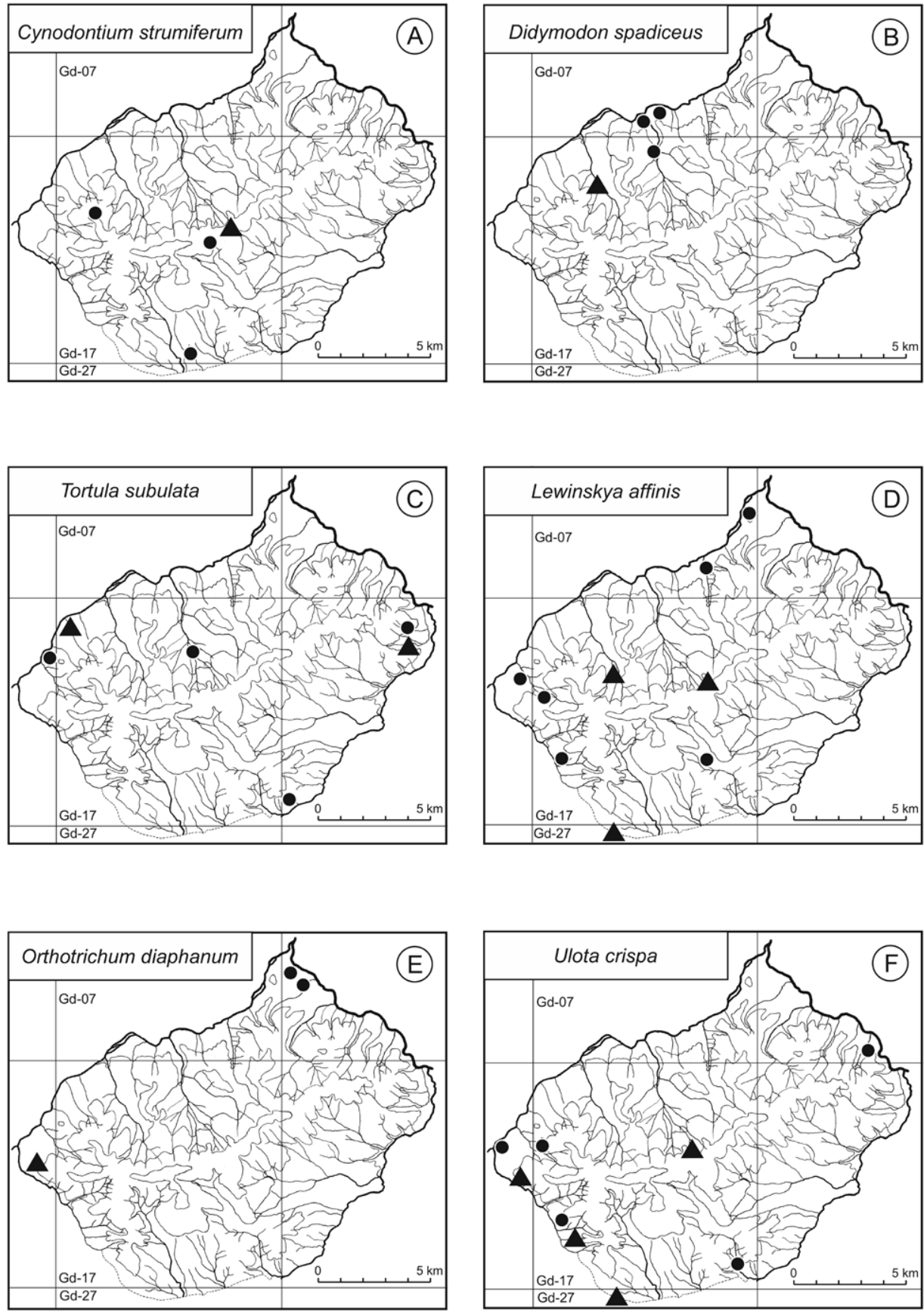

Ryc. 19. Rozmieszczenie bardzo rzadkich i rzadkich gatunków mchów w Paśmie Policy. Nowe stanowiska oznaczone są trójkątami

Fig. 19. Distribution of very rare and rare moss species in the Polica Range. New localities are marked with triangles Cynodontium strumiferum (A), Didymodon spadiceus (B), Tortula subulata (C), Lewinskya affinis (D), Orthotrichum diaphanum (E), Ulota crispa (F) 
i Skalicach Nowotarskich i Spiskich (OchYRA 1984) i tylko nieco częstszy w Małych Pieninach (OCHYRA \& STEBEL 2008).

Tortula subulata Hedw.

(Ryc. 19C)

(1) Zawoja Centrum, 49³9'39,6"N, 19³3'35,8'E, 530-535 m n.p.m., na starym piaskowcowym i cementowym murze koło kościoła, ATMOS Gd-17, 23.08.2000, Stebel s.n. (KRAM B-142818 jako T. mucronifolia Schwägr.); to samo stanowisko, 14.06.2019, Stebel s.n. (KRAM B-248065, SOSN); (2) potok Bystrzanka w Bystrej, 49³7'03"N, 1943'43"E, 630 m n.p.m., 13.10.1978, Ochyra 2193/78 (KRAM B-224014).

Rzadki gatunek, podawany dotychczas z czterech stanowisk w Paśmie Policy, występujących $w$ piętrze pogórza $i \mathrm{w}$ dolnych rejonach regla dolnego (STEBEL $\mathrm{i}$ in. 2004). Rewizja okazu zielnikowego podanego z Pasma Policy jako Tortula mucronifolia (STEBEL i in. 2004) wykazała, że należy on faktycznie do T. subulata i został początkowo zaliczony do osobnej odmiany, var. graeffii Warnst. (STEBEL 2006a). Jak wykazały badania (CANO i in. 2005) jej wartość systematyczna jest wątpliwa, gdyż mieści się ona w granicach zmienności $T$. subulata. Odmiana ta ma przejrzyste komórki blaszki liściowej i niezbyt wyraźne obrzeżenie liści w górnej części oraz stosunkowo niską błonę podstawową ozębni, przez co powierzchownie upodabnia się do dużych form T. mucronifolia. Pomimo to brodawkowanie komórek liścia jest bardzo wybitne i dość gęste i występuje na wszystkich komórkach, aczkolwiek jest bardzo delikatne i przy nieuważnym badaniu może być łatwo przeoczone. Jednakże wskazuje ono jednoznacznie na przynależność takich form do T. subulata. Tym samym T. mucronifolia musi być wykreślona z flory mchów Pasma Policy oraz automatycznie z flory mchów Beskidów Zachodnich, gdyż było to jedyne doniesienie o jego występowaniu z tych gór. Tortula subulata znana jest z wszystkich pasm zachodniobeskidzkich, od Beskidu Śląskiego po Beskid Niski (MAMCZARZ 1977; Karczmarz 1987; Stebel 2006a; Stebel \& VončIna 2014) i wszędzie jest gatunkiem bardzo rzadkim lub rzadkim. Równie rzadko występuje w całym Pienińskim Pasie Skałkowym (Ochyra 1984; Ochyra \& Stebel 2008; Stebel i in. 2010) oraz w Tatrach (OChYRA \& CisŁo 1999).

\section{Orthotrichaceae Arn.}

Lewinskya affinis (Brid.) F.Lara, Garilleti \& Goffinet

(Ryc. 19D, 20)

(1) Zubrzyca Górna, na wschód od Śmietanowej Polany obok drogi Rajsztag, 818 m n.p.m., 49³4'32,4"N, $19^{\circ} 36^{\prime 25}, 1^{\prime \prime} \mathrm{E}$, na korze przydrożnej Salix caprea, ATMOS Gd-27, 21.06.2019, Stebel s.n. (KRAM B-250012); (2) między Czarnotową a Malikową $4 \mathrm{~km}$ na południe od Zawoi Fujacy, las świerkowy nad Skawicą Górną, 690-765 m n.p.m., 49³8'17"N, 19³5'59"E, na korze Salix sp., ATMOS Gd-17, 7.07.2017, Ochyra \& Klama 1461/17 (KRAM B-243706); (3) Okragglica na wschód od Hali Krupowej w głównym grzbiecie pasma, 1216-1246 m n.p.m., 49 $37^{\prime} 38^{\prime \prime} \mathrm{N}, 1^{\circ} 39^{\prime} 19^{\prime \prime} \mathrm{E}$, na korze Salix caprea razem z Orthotrichum speciosum Nees, 6.07.2017, Ochyra \& Klama 206/17 (KRAM B-240737).

Gatunek występujący na rozproszonych stanowiskach w różnych częściach polskich Karpat (Lisowski 1956c; OchYRA 1984; STEBel 2006a, 2008, 2010a, b; OchYRA \& STEBEL 2008; Stebel i in. 2010, 2017; Stebel \& VonČina 2017). W Paśmie Policy jest gatunkiem rzadkim, znanym do tej pory tylko z sześciu stanowisk (Ryc. 20). 


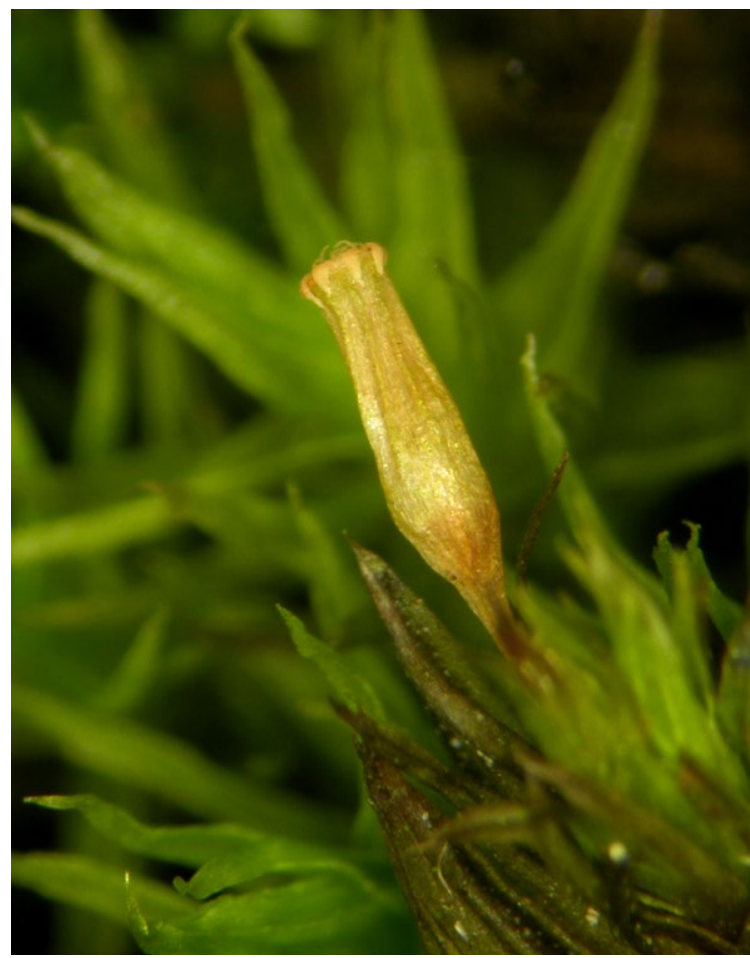

Ryc. 20. Lewinskya affinis (fot. V. Plášek)

Fig. 20. Lewinskya affinis (photo by V. Plášek)

Orthotrichum diaphanum Brid.

(Ryc. 19E, 21)

Zawoja, dolina potoku Jaworzyna, 656 m n.p.m., 49 37'22,0'N, 19³2'19,1"E, na korze pnia Acer pseudoplatanus na brzegu Jaworzyny naprzeciw ujścia Rybnego Potoku, ATMOS Gd-16, 10.08.2019, Stebel s.n. (KRAM B-249906).

Do niedawna gatunek ten był rzadki w polskiej części Karpat, lecz obecnie znany jest z większości regionów, zwłaszcza w ich zachodniej części (STEBEL 2006a, 2008, 2010a, b; Ochyra \& Stebel 2008; Stebel i in. 2010, 2017; Stebel \& VončInA 2017). W Paśmie Policy jest to gatunek bardzo rzadki, znany do tej pory z zaledwie dwóch stanowisk położonych we wschodniej części badanego terenu (Ryc. 21).

Ulota crispa (Hedw.) Brid.

(Ryc. 19F)

(1) Zawoja Policzne, 705 m n.p.m., 49 $36^{\prime} 49,8^{\prime \prime} \mathrm{N}, 19^{\circ} 33^{\prime} 04,1^{\prime \prime} \mathrm{E}$, na korze przydrożnej Salix caprea, ATMOS Gd-16, 14.06.2019, Stebel s.n. (KRAM B-248062); (2) na południowy-zachód od klifu Łysina przy trakcie leśnym na północnych stokach głównego grzbietu pasma poniżej Złotej Grapy, 1050 m n.p.m., $49^{\circ} 37^{\prime} 47^{\prime \prime} \mathrm{N}, 1^{\circ} 38^{\prime} 12^{\prime \prime} \mathrm{E}$, na korze pnia starego buka, ATMOS Gd-17, 6.07.2017, Ochyra \& Klama 266/17 (KRAM B-240895); (3) Zawoja, dolina potoku Jaworzyna, 753 m n.p.m., 49 $36^{\prime} 22,9^{\prime \prime} \mathrm{N}, 1^{\circ} 33^{\prime} 45,0^{\prime \prime} \mathrm{E}$, na korze przydrożnego Fraxinus excelsior obok drogi Zawoja - Zubrzyca, ATMOS Gd-17, 10.08.2019, Stebel s.n. (KRAM B-249908); (4) Zubrzyca Górna, na wschód od Śmietanowej Polany obok drogi Rajsztag, 818 m n.p.m., 49³4'32,4"N, 19³6'25,1"E, na korze przydrożnej Salix caprea, ATMOS Gd-27, 21.06.2019, Stebel s.n. (KRAM B-250011). 


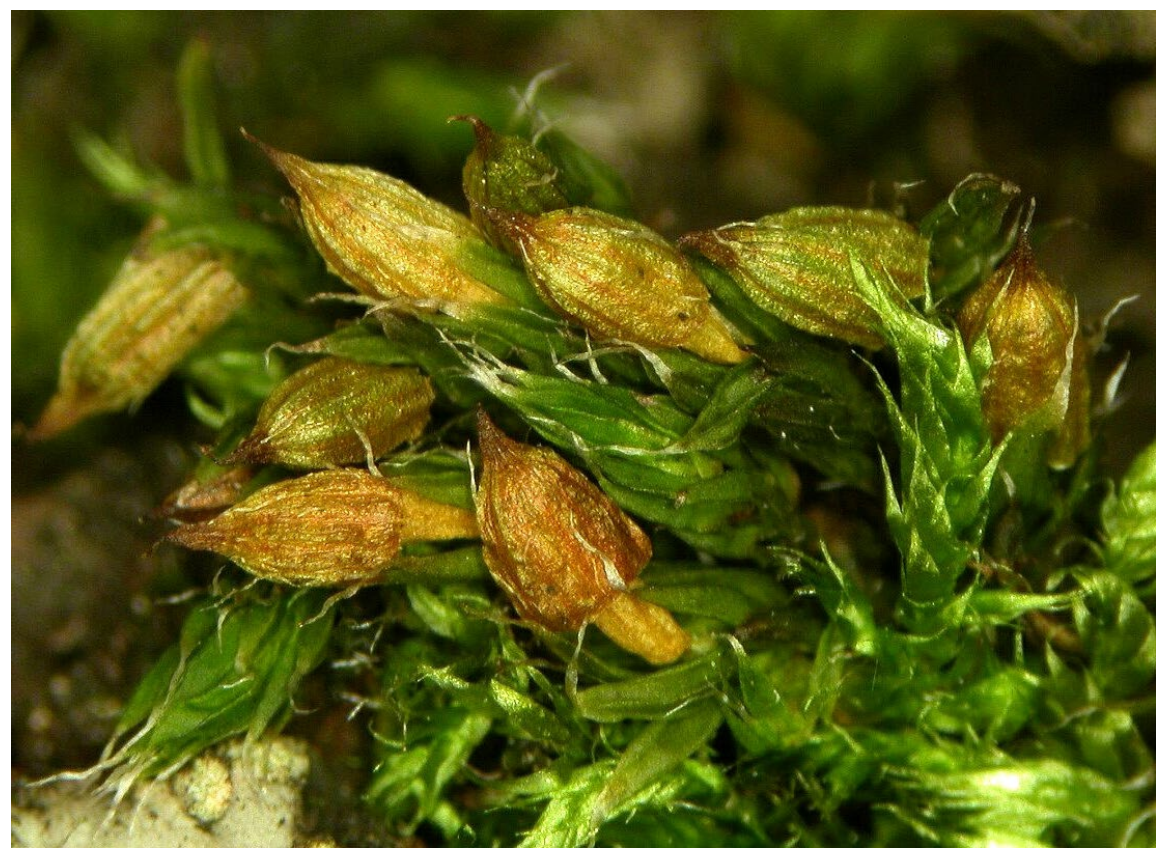

Ryc. 21. Orthotrichum diaphanum (fot. V. Plášek)

Fig. 21. Orthotrichum diaphanum (photo by V. Plášek)

Rzadki epifityczny gatunek, rosnący na korze liściastych drzew i krzewów na pogórzu oraz w dolnych i środkowych partiach regla dolnego. Dotychczas znany był z pięciu stanowisk (STEBEL i in. 2004), a cztery dalsze podane są w niniejszym artykule. Jedno z nich zostało znalezione na wysokości 1050 m n.p.m. w górnej części regla dolnego i jest to drugie najwyżej położone stanowisko Ulota crispa w Beskidach Zachodnich. Najwyższe stanowisko tego gatunku w Beskidach Zachodnich zostało znalezione na wysokości $1100 \mathrm{~m}$ n.p.m. w Gorcach (LISOwSKI \& KoRNAŚ 1966), natomiast w polskich Karpatach najwyżej położone stanowiska znane są z Tatr, gdzie osiąga on maksimum wysokościowe $1460 \mathrm{~m}$ n.p.m (ChaŁubiŃski 1886 jako $U$. intermedia Schimp.). Generalnie, jeszcze do niedawna $U$. crispa była gatunkiem bardzo rzadkim w Beskidach Zachodnich, rosnącym w rozproszeniu w większości pasm tego łańcucha górskiego (STEBEL 2006a). Obecnie jest gatunkiem coraz częściej notowanym, a liczba jego stanowisk szybko rośnie.

\section{Mniaceae Schwägr.}

Mnium hornum Hedw.

(Ryc. 22, 23A)

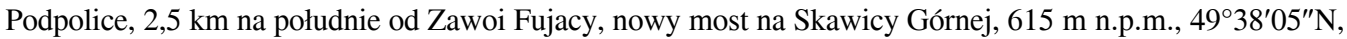
$19^{\circ} 35^{\prime} 38^{\prime \prime} \mathrm{E}$, na mokrej glebie pomiędzy piaskowcowymi blokami koło mostu, ATMOS Gd-17, 7.07.2017, Ochyra \& Klama 414/17 (KRAM B-243988).

Bardzo rzadki gatunek, znaleziony dotychczas w Paśmie Policy na dwóch stanowiskach w dolnych partiach regla dolnego (STEBEL i in. 2004) (Ryc. 22). Równie bardzo 
rzadki w całym Beskidzie Wysokim, Beskidzie Wyspowym, Gorcach, Beskidzie Sądeckim i na Działach Orawskich, ale już pospolity w Beskidzie Śląskim, częsty w Beskidzie Małym i Beskidzie Niskim i dość częsty w Kotlinie Żywieckiej i Beskidzie Makowskim (MAMCZarz 1977; Karczmarz 1979, 1987; Stebel \& Ochyra 2000; Stebel 2006a; Stebel \& VončIna 2014). Ostatnio odnaleziony został w Pienińskim Pasie Skałkowym (VonČınA \& STEBel 2016). Ma to zapewne związek z wyraźnymi tendencjami oceanicznymi Mnium hornum, które występuje pospolicie w całej Europie Zachodniej, stając się wyraźnie rzadszy ku wschodowi.

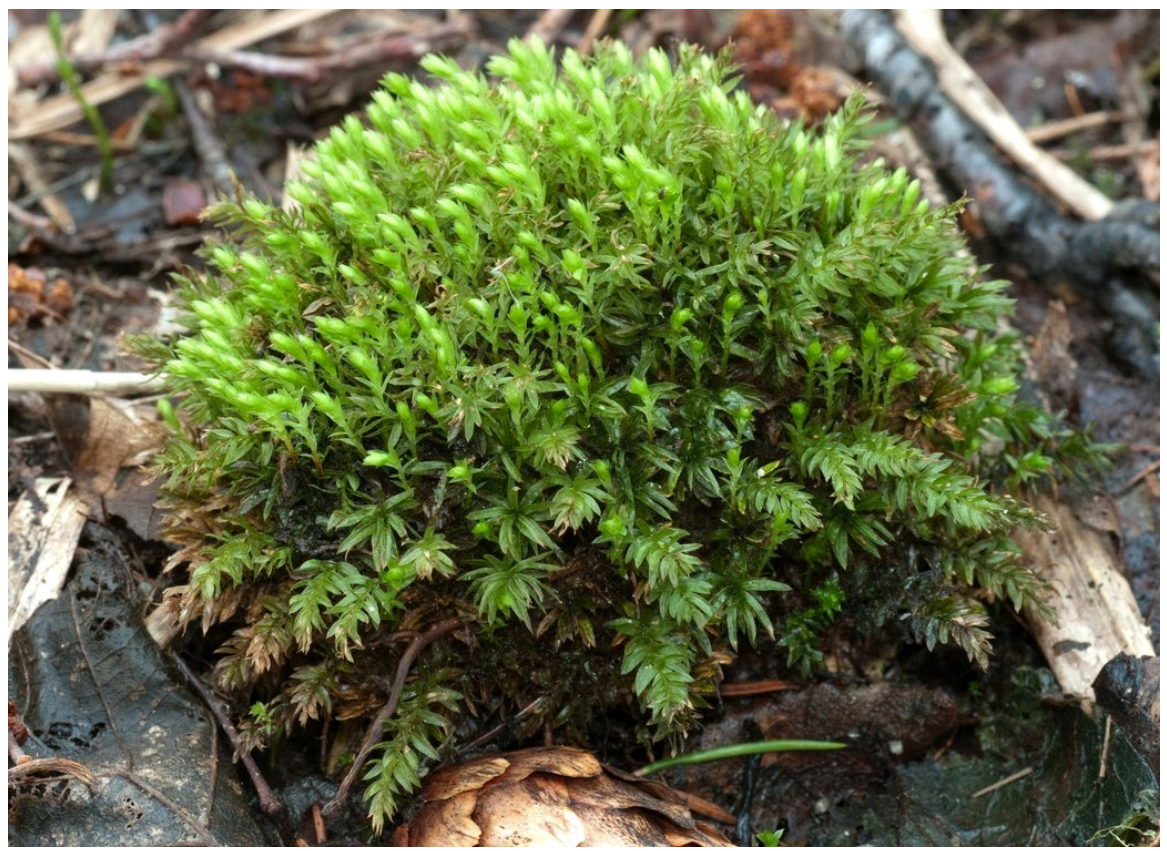

Ryc. 22. Mnium hornum (fot. V. Plášek)

Fig. 22. Mnium hornum (photo by V. Plášek)

Mnium spinosum (Voit) Schwägr.

(Ryc. 23B)

(1) Podpolice 2,5 km na południe od Zawoi Fujacy, nowy most na Skawicy Górnej, $615 \mathrm{~m}$ n.p.m., $49^{\circ} 38^{\prime} 05^{\prime \prime} \mathrm{N}, 19^{\circ} 35^{\prime} 38^{\prime \prime} \mathrm{E}$, na mokrej glebie przy filarze mostu, ATMOS Gd-17, 7.07.2017, Ochyra \& Klama 412/17 (KRAM B-243986); (2) Czarnotowa 4 km na południe od Zawoi Fujacy, 690 m n.p.m., 49³8'27"N, $19^{\circ} 36^{\prime} 6^{\prime \prime} \mathrm{E}$, 'E, na mokrej kłodzie w potoku, ATMOS Gd-17, 7.07.2017, Ochyra \& Klama 375/17 (KRAM B-241232).

Bardzo rzadki gatunek, znany tylko z dwóch stanowisk w środkowych partiach regla dolnego (STEBEL i in. 2004). Oba nowe stanowiska położone są w dolnych partiach regla dolnego i zmieniają one nieco status tego gatunku na rzadki. W Beskidach Zachodnich Mnium spinosum jest ogólnie gatunkiem bardzo rzadkim, znanym tylko z niektórych pasm (Beskid Śląski, Beskid Wysoki, Beskid Mały, Gorce, Działy Orawskie, Beskid Sądecki) 

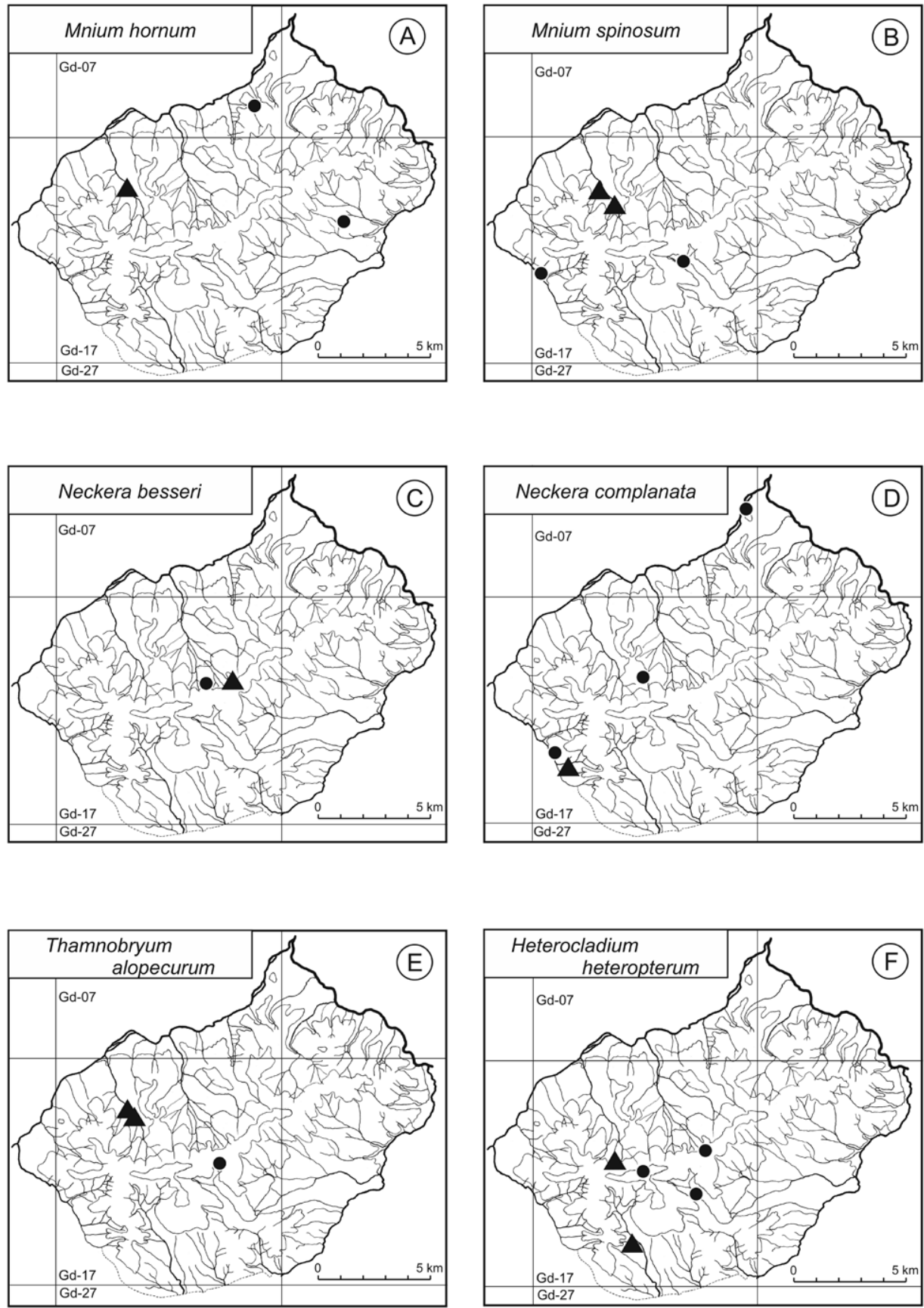

Ryc. 23. Rozmieszczenie bardzo rzadkich i rzadkich gatunków mchów w Paśmie Policy. Nowe stanowiska oznaczone są trójkątami

Fig. 23. Distribution of very rare and rare moss species in the Polica Range. New localities are marked with triangles Mnium hornum (A), M. spinosum (B), Neckera besseri (C), N. complanata (D), Thamnobryum alopecurum (E), Heterocladium heteropterum $(\mathrm{F})$ 
(MamcZarz 1977; Stebel 2006a; Stebel \& VonČIna 2014). Jest natomiast gatunkiem częstym w Skalicach Nowotarsko-Spiskich (OchYRa 1984), Pieninach (SteBel i in. 2010) oraz w Tatrach (LISOwSKi 1959; OCHYRA \& CisŁo 1999).

\section{Neckeraceae Schimp.}

Neckera besseri (Lobarz.) Jur.

(Ryc. 23C)

Okrąglica na wschód od Hali Krupowej w głównym grzbiecie pasma, 1240 m n.p.m., 49³7'38"N, $19^{\circ} 39^{\prime} 19^{\prime \prime}$ E, zacieniony głaz piaskowcowy w lesie świerkowym, 6.07.2017, Ochyra \& Klama 180/17 (KRAM B-240751).

W Paśmie Policy Neckera besseri jest bardzo rzadkim gatunkiem znanym dotychczas tylko z jednego stanowiska na klifie Łysina na wschód od Złotej Grapy (STEBEL i in. 2004). Jest także bardzo rzadkim gatunkiem w całych Beskidach Zachodnich (Beskid Śląski, Beskid Makowski, Beskid Wysoki, Beskid Wyspowy, Gorce, Beskid Sądecki) (MamcZarz 1977; STEBEL 2006a), chociaż w Gorcach został ostatnio znaleziony na czterech stanowiskach (STEBEL i in. 2017). Ten wapieniolubny gatunek w polskich Karpatach występuje najczęściej w Pienińskim Pasie Skałkowym (OchYra 1984; OchYRa \& Stebel 2008; Stebel i in. 2010), a poza nim był notowany tylko sporadycznie w Beskidach Zachodnich i Beskidzie Niskim (Ochyra i in. 1988c; Stebel 2006a; Stebel \& Ochyra 2000). Poza górami występuje najczęściej na Wyżynie Krakowsko-Częstochowskiej (OchYRA i in. 1988c; FoJCIK 2011a, b), w Górach Świętokrzyskich (KuC 1964) i na Roztoczu (Zubel i in. 2015).

Neckera complanata (Hedw.) Huebener

(Ryc. 23D)

Zawoja, dolina potoku Jaworzyna, 761 m n.p.m., 49 $36^{\prime} 14,6^{\prime \prime} \mathrm{N}, 19^{\circ} 33^{\prime} 50,7^{\prime \prime}$, na korze Fagus sylvatica na skarpie nad potokiem, ATMOS Gd-17, 10.08.2019, Stebel s.n. (KRAM B-249909).

Gatunek podawany z wielu rejonów Karpat (OCHYRA i in. 1988b), jednakże jako epifit obecnie spotykany jest bardzo rzadko. W Paśmie Policy znany był do tej pory z trzech stanowisk. W dolinie Jaworzyny gatunek ten zebrany został już wcześniej na wysokości 740 m n.p.m. (STEBEL i in. 2004). Podczas niniejszych badań stanowisko to zostało potwierdzone, a dodatkowo okazy obserwowane były także na nieco wyżej położonym miejscu.

\section{Thamnobryaceae Margad. \& During}

Thamnobryum alopecurum (Hedw.) Gangulee

(Ryc. 23E, 24)

(1) Podpolice 2,5 km na południe od Zawoi Fujacy, głazy na lewym brzegu Skawicy Górnej koło nowego mostu, 615 m n.p.m., $49^{\circ} 38^{\prime} 05^{\prime \prime} \mathrm{N}, 19^{\circ} 35^{\prime} 38^{\prime \prime} \mathrm{E}$, na wilgotnych piaskowcowych blokach, ATMOS Gd-17, 7.07.2017, Ochyra \& Klama 415/17, 420/17, 421/17 \& 438/17 (KRAM B-243989, 243993, 243994 \& 244013); (2) Podpolice $2 \mathrm{~km}$ na południe od Zawoi Fujacy, na północ od nowego mostu na Skawicy Górnej, 600-615 m n.p.m., 49 38'35"N, 19³5'36"E, na mokrym głazie piaskowcowym w korycie potoku, ATMOS Gd-17, 5.10.2017, Ochyra \& Klama 1730/17 (KRAM B-243863).

Podobnie jak w prawie wszystkich innych pasmach zachodniobeskidzkich (STEBEL 2006a), Thamnobryum alopecurum jest gatunkiem bardzo rzadkim w Paśmie Policy, znanym dotychczas tylko z jednego stanowiska na Hali Krupowej w szczytowych partiach tego 


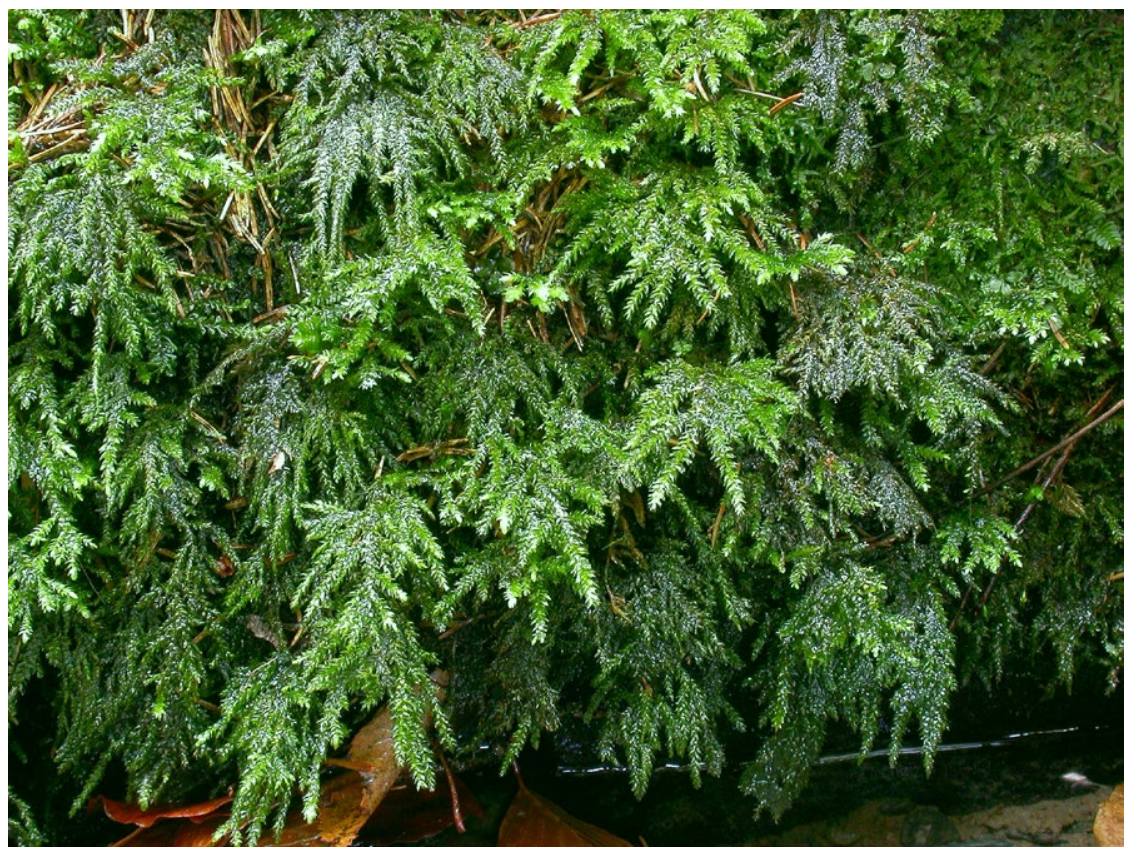

Ryc. 24. Thamnobryum alopecurum (fot. V. Plášek)

Fig. 24. Thamnobryum alopecurum (photo by V. Plášek)

pasma (STEBEL $\mathrm{i}$ in. 2004) (Ryc. 23E). Nowo odkryte stanowisko tego gatunku, znajdujące się w potoku Skawica Górna na odcinku 2-2,5 km na południe od Zawoi Fujacy, jest niezwykle bogate i gatunek ten rośnie tu masowo na blokach skalnych w łożysku potoku, zwłaszcza w okolicach nowego mostu. Ten wapieniolubny gatunek występuje w polskich Karpatach najczęściej w Pienińskim Pasie Skałkowym (OCHYRA 1984; OchYRA \& STEBEL 2008; SteBel i in. 2010) oraz sporadycznie w Beskidzie Śląskim, Beskidzie Sądeckim, Beskidzie Małym, Beskidzie Wysokim i Beskidzie Niskim (BEDNAREK-OCHYRA i in. 1994; STEBel 2006a). Poza górami Th. alopecurum występuje dość często na Wyżynie Krakowsko-Częstochowskiej (BEDNAREK-OCHYRA i in. 1994; FoJCIK 2011a, b), w Górach Świętokrzyskich (KuC 1964) oraz na Roztoczu (Zubel i in. 2015). Stanowisko w projektowanym Turnickim Parku Narodowym w Górach Sanocko-Turczańskich w Beskidach Wschodnich (BURY 2018) wymaga potwierdzenia.

\section{Pterigynandraceae Schimp.}

Heterocladium heteropterum Schimp.

(Ryc. 23F)

(1) Ochlipów między Przełęczą Krowiarki i Zubrzycą Górną w południowej części doliny Białego Potoku między Polaną Knopówki i Polaną Nowiny u południowego podnóża Policy, 865 m n.p.m., 49³5'36"N, $19^{\circ} 37^{\prime} 08^{\prime \prime} \mathrm{E}$, na ocienionym głazie piaskowcowym w lesie świerkowym, ATMOS Gd-17, 5.07.2017, Ochyra \& Klama 58/17 (KRAM B-240455); (2) między przysiółkami Czarnotowa i Malikowa 5 km na południe od Zawoi Fujacy, w obszarze źródliskowym jednego z orograficznie lewych dopływów Skawicy Sołtysiej, na południowy-wschód od przysiółka Kowalowa, 788 m n.p.m., 49³8'6"N, 19³5'51"E, 
na ocienionym głazie piaskowcowym w lesie świerkowym razem z Hookeria lucens (Hedw.) Sm., ATMOS Gd-17, 5.10.2017, Ochyra \& Klama 1545/17 (KRAM B-243796).

Bardzo rzadki gatunek naskalny, dotychczas znany tylko $\mathrm{z}$ trzech stanowisk, w tym dwóch znajdujących się w najwyższych partiach Pasma Policy. Dwa nowe stanowiska Heterocladium heteropterum zostały znalezione na typowych dla tego gatunku siedliskach, czyli na ocienionych głazach piaskowcowych w lasach świerkowych. Niemniej jednak pozostaje on nadal rzadkim gatunkiem w Paśmie Policy, podobnie jak w Gorcach, Beskidzie Wyspowym i Beskidzie Wysokim, chociaż ostatnio został znaleziony na dalszych trzech stanowiskach w tym pierwszym paśmie (STEBEL i in. 2017). Jedynie w Beskidzie Śląskim i Beskidzie Małym $H$. heteropterum był częściej znajdowany, co jest być może efektem lepszego zbadania tych pasm (STEBel 2006a). Również w Tatrach i Beskidzie Niskim H. heteropterum jest gatunkiem bardzo rzadkim (BEDNAREK-OCHYRA i in. 1990b; BEDNAREK-OCHYRA 1991; STEBEL 2011). Ostatnio odnaleziony został również na Pogórzu Rożnowskim w rezerwacie „Styr” (STEBEL 2016a).

\section{Hylocomiaceae M.Fleisch.}

Rhytidiaelphus subpinnatus (Lindb.) T.J.Kop.

(Ryc. 25, 26)

(1) Podpolice $2 \mathrm{~km}$ na południe od Zawoi Fujacy, na północ od nowego mostu na Skawicy Sołtysiej, 600615 m n.p.m., $49^{\circ} 38^{\prime} 35^{\prime \prime} \mathrm{N}, 1^{\circ} 35^{\prime} 36^{\prime \prime} \mathrm{E}$, w lesie świerkowym na ocienionym i suchym zboczu, ATMOS Gd-17, 5.10.2017, Ochyra \& Klama 1609/17 (KRAM B-243857); (2) Skawica Sucha Góra, Sitarka 4 km na południe od Skawicy, wzdłuż jednego ze źródłowych potoków Skawicy Sołtysiej w kierunku Lasu Suwark,

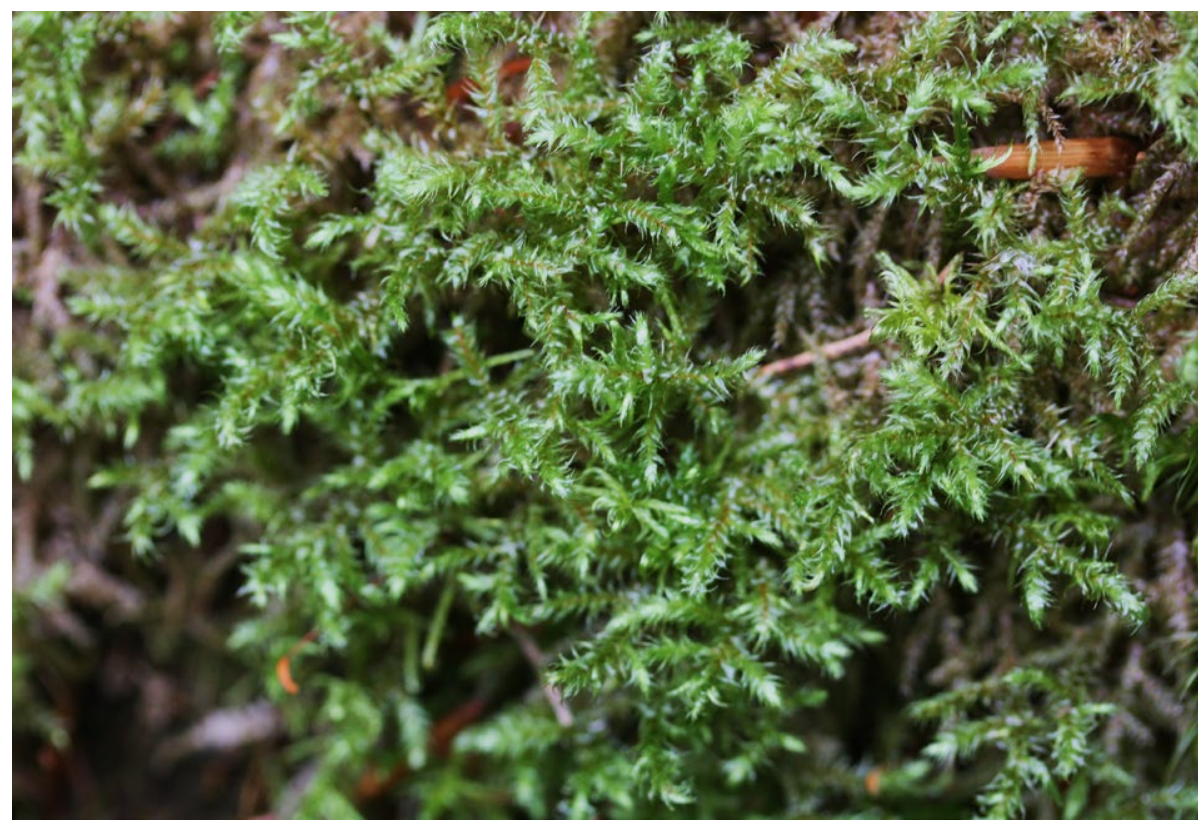

Ryc. 25. Rhytidiadelphus subpinnatus (fot. A. Stebel)

Fig. 25. Rhytidiadelphus subpinnatus (photo by A. Stebel) 


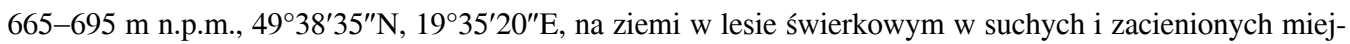
scach, ATMOS Gd-17, 6.10.2017, Ochyra \& Klama 1646/17 \& 1658/17 (KRAM B-243920 \& 243909).

Rzadki gatunek leśny, znany dotychczas tylko z sześciu stanowisk, skupionych w wyższych partiach regla dolnego i w reglu górnym (STEBeL i in. 2004) (Ryc. 25). Nowe stanowiska zostały stwierdzone w dolnych partiach regla dolnego, w dobrze zachowanych płatach lasów świerkowych, gdzie mech ten rośnie w dużej obfitości. Wskazuje to, że gatunek ten może okazać się częstszym niż wynikałoby to z dotychczasowych danych. Potwierdzają

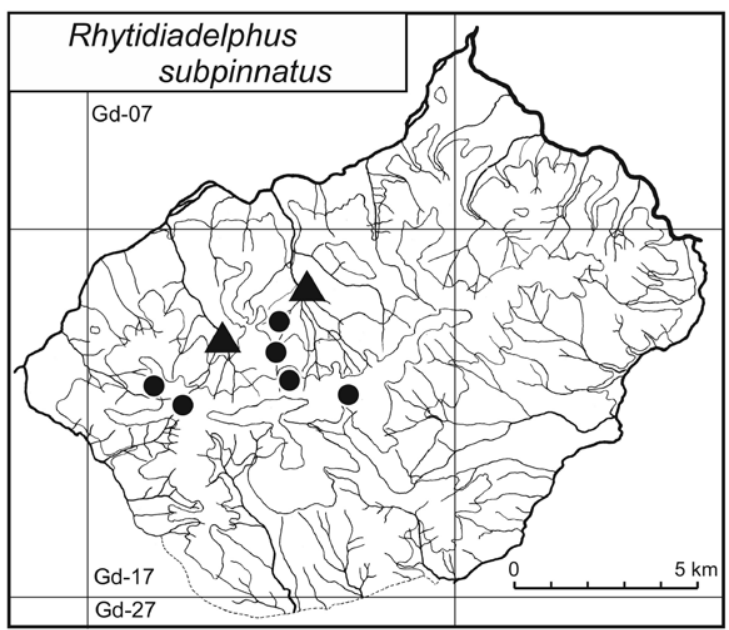

Ryc. 26. Rozmieszczenie Rhytidiadelphus subpinnatus w Paśmie Policy. Nowe stanowiska oznaczone są trójkątami

Fig. 26. Distribution of Rhytidiadelphus subpinnatus in the Polica Range. New localities are marked with triangles

to dane z innych pasm, na przykład Gorców, gdzie Rhytidiadelphus subpinnatus był traktowany jako rzadki (STEBel 2006a; Stebel \& CzARNota 2012), a ostatnio stwierdzony został na czterech nowych stanowiskach (STEBEL i in. 2017). W innych pasmach zachodniobeskidzkich gatunek wykazuje podobną częstość występowania, od bardzo rzadkiego (Beskid Makowski, Beskid Niski, Beskid Wyspowy, Kotlina Żywiecka) poprzez rzadki (Gorce, Pogórze Orawsko-Jordanowskie) i dość częsty (Beskid Wysoki) do częstego (Beskid Śląski) (WaCŁawsKa 1957; Stebel 2006a; STEBel \& VonČINA 2014). Do tej pory nie jest znany tylko z Beskidu Małego (SteBel 2010a).

\section{DYSKUSJA}

W opublikowanej 15 lat temu Florze mchów, z Pasma Policy podano 264 gatunki i 5 odmian (STEBEL $i$ in. 2004), przy czym należy dodać, że opracowanie to zostało oparte w znacznej mierze na materiałach zebranych w latach 60. i w końcu lat 70. ubiegłego wieku. Biorąc pod uwagę ówczesny stan zbadania brioflory Beskidów Zachodnich, były to liczby znaczące, które stawiały Pasmo Policy w grupie nie tylko najlepiej zbadanych, ale i najbogatszych 
pod względem brioflorystycznym pasm w polskich Karpatach, z wyjątkiem Tatr. Według zestawienia KARCZMARZA (1987), najbogatszą florę mchów miał wówczas Beskid Sądecki - 260 gatunków, który tylko nieznacznie wyprzedzał Bieszczady Zachodnie i Beskid Niski - oba pasma po 252 gatunki, Pieniny - 250 gatunków oraz Gorce - 247 gatunków i Babią Górę - 222 gatunki. Inne pasma miały zdecydowanie uboższą florę mchów: Beskid Śląski - 183 gatunki, Beskid Mały - 126 gatunków i Beskid Wyspowy - 120 gatunków. Oczywiście, należy podkreślić, że liczby te odzwierciedlały raczej stan zbadania niż realną florę mchów w tych pasmach. Trzeba też dodać, że zestawienie to nie uwzględniało Skalic Nowotarskich i Spiskich, w których stwierdzono wówczas 249 gatunków mchów (OcHYRA 1984). Pasmo Policy z 203 gatunkami plasowało się w środku stawki w tym rankingu, ale uwzględniając dane opublikowane we Florze z 2004 r., posiadało ono w owym czasie najbogatszą muskoflorę w całych polskich Karpatach, liczącą 264 gatunki (STEBEL i in. 2004).

Statystyka ta zmieniła się radykalnie w dwie dekady później, gdy drugi z autorów (AS) rozpoczął intensywne badania flory mchów polskich Karpat Zachodnich, ze szczególnym uwzględnieniem Beskidów Zachodnich (np. STEBEL 1999, 2000, 2003b, c, 2004a, b, c, d, e, 2006a, b, c, d; STebel \& Stebel 1998; STebel \& Ochyra 2000; Stebel \& WilczeK 2000; Plášek \& Stebel 2002; Stebel \& Górski 2004; Stebel i in. 2004). Zaowocowały one ogromnym wzrostem informacji na temat różnorodności gatunkowej i chorologii mchów na tym obszarze, które zostały podsumowane w syntetycznym opracowaniu poświęconym florze mchów Beskidów Zachodnich (STEBEL 2006a). W przypadku bioróżnorodności, najważniejszym efektem tych prac było przede wszystkim urealnienie danych dotyczących bogactwa gatunkowego poszczególnych pasm zachodniobeskidzkich.

Zgodnie z przewidywaniami, najbogatszą florę mchów, liczącą 356 gatunków, 1 podgatunek i 11 odmian, posiada Beskid Wysoki (A. Stebel, dane npbl.). Nie tylko zajmuje on największą powierzchnię spośród wszystkich pasm w Beskidach Zachodnich, ale wykazuje również największe zróżnicowanie siedliskowe, m.in. dzięki dobrze wykształconemu piętru alpejskiemu w masywie Babiej Góry. Pozostałe jednostki fizjograficzne Beskidów Zachodnich układają się w trzy wyraźne grupy pod względem bogactwa gatunkowego. Jedną z nich tworzy Beskid Śląski, w którym zanotowano 302 gatunki i 3 odmiany mchów. Do drugiej grupy należą Gorce, w których stwierdzono 271 gatunków i 9 odmian mchów oraz Beskid Mały, którego flora mchów obejmuje 251 gatunków i 5 odmian. Do tej grupy należy także Pasmo Policy, którego muskoflora liczyła wówczas 264 gatunki i 5 odmian. Wreszcie ostatnią, trzecią grupę, o prawie identycznej bioróżnorodności flory mchów, stanowią: Kotlina Żywiecka - 234 gatunki i 6 odmian, Beskid Wyspowy - 233 gatunki i 5 odmian oraz Beskid Makowski - 232 gatunki i 4 odmiany.

Podobnie jak badania taksonomiczne, również badania florystyczne i fitogeograficzne mają charakter dynamiczny i są praktycznie nigdy nie kończącą się syntezą. Badania terenowe prowadzone przez kilkanaście lat, które upłynęły od opublikowania syntezy fitogeograficznej, ekologicznej i ochroniarskiej flory mchów Beskidów Zachodnich (STEBEL 2006a), zaowocowały nagromadzeniem licznych nowych danych do flory mchów tego obszaru. Ich efektem były, z jednej strony, monograficzne opracowania flor kolejnych pasm górskich: Beskidu Małego (Stebel 2010) i Pogórza Orawsko-Jordanowskiego (Stebel \& VonČina 2014) oraz katalogu mchów masywu Babiej Góry (STEBEL i in. 2018), a z drugiej strony 
dopełnienia do flor mchów rozmaitych pasm górskich, które zmieniły dotychczasową statystykę ich bogactwa gatunkowego.

Do najbardziej znaczących znalezisk florystycznych w polskiej części Karpat, mających istotną wartość fitogeograficzną, należą odkrycia Coscinodon cribrosus (Hedw.) Spruce i Fontinalis squamosa Hedw. w Beskidzie Śląskim (BEDNAREK-OCHYRA \& STEBEL - W: Ellis i in. 2014; Stebel \& Zubel 2018) i Grimmia crinita Brid. na Pogórzu Śląskim (STeBel \& ZUBEL 2018), które są gatunkami nowymi dla polskich Karpat oraz Thamnobryum neckeroides (Hook.) E.Lawton w Beskidzie Śląskim i w Pieninach, będącego nowym dodatkiem do flory mchów Polski i oczywiście polskich Karpat (STEBel \& Vončina 2018). Gatunkiem nowym dla Beskidów Zachodnich, znanym dotychczas z piętra alpejskiego w Tatrach (OchYRA \& SzMAJDA 1983) jest Amphidium lapponicum (Hedw.) Schimp., który został znaleziony na Babiej Górze (OchYRA - W: Ellis i in. 2019a). Uwzględniając powyższe dane, flora mchów masywu Babiej Góry liczy obecnie 280 gatunków, 1 podgatunek i 7 odmian (STEBEL $i$ in. 2018; Ellis i in. 2019a), a Beskidu Śląskiego 304 gatunki i 3 odmiany (STEBEL 2006; ElLis i in. 2014; STEBel $i$ in. 2018).

Badania terenowe prowadzone $\mathrm{w}$ innych pasmach zachodniobeskidzkich doprowadziły do wzbogacenia ich flor mchów o dalsze gatunki. I tak, w Beskidzie Małym znaleziono dalszych 9 gatunków i 3 odmiany, dzięki czemu obecnie muskoflora tego pasma liczy 260 gatunków i 8 odmian. Z kolei w Gorcach flora mchów wzbogaciła się o 15 gatunków (STEBel \& CZarnota 2012; Stebel i in. 2016, 2017) i liczy obecnie 286 gatunków i 9 odmian. O taką samą liczbę gatunków wzbogaciła się również flora mchów Pasma Policy. Są one szczegółowo omówione w niniejszym opracowaniu. Jednocześnie krytyczna rewizja materiału zielnikowego, na podstawie którego podano Tortula mucronifolia z Pasma Policy, przeprowadzona w trakcie obecnych badań wykazała, że faktycznie okaz ten reprezentuje polimorficzny gatunek T. subulata. Tym sposobem flora mchów Pasma Policy liczy obecnie 278 gatunków i 5 odmian.

Większość nowo znalezionych w Paśmie Policy gatunków należy do rzadkich mchów w skali kraju i Karpat, co dowodzi, że podstawowy trzon flory mchów tego pasma zawiera dość wyczerpujący zestaw gatunków, które są szeroko rozmieszczone w całych Karpatach. Występowanie tych rzadkich gatunków jest często uwarunkowane dostępnością specyficznych lokalnych mikrosiedlisk, przez co mogły być one z łatwością przeoczone, zarówno $\mathrm{w}$ badanym terenie, jak i w innych pasmach zachodniobeskidzkich. Odkrycia niektórych z tych gatunków w Paśmie Policy można było się spodziewać, np. Hookeria lucens, gdyż gatunek ten występuje nierzadko w sąsiednim masywie Babiej Góry. Również znalezienia gatunków z rodzaju Orthotrichum Hedw., tj. O. pallens i O. stramineum oraz Lewinskya striata, pomimo ich ogólnej rzadkości, można się było spodziewać w badanym terenie, $\mathrm{z}$ racji chociażby obserwowanego w ostatnich latach rozprzestrzeniania się gatunków epifitycznych w Karpatach (STEBEL 2006c).

Również gatunki z rodzaju Schistidium Bruch \& Schimp. są nadal wielką niewiadomą w Europie Środkowej, tak od strony taksonomicznej, jak i fitogeograficznej, z tego powodu, że dopiero niedawno trudny kompleks $S$. apocarpum został krytycznie zbadany od strony systematycznej, ale głównie w Skandynawii (BLOM 1996). Efektem tych badań było opisanie szeregu nowych dla nauki gatunków oraz wskrzeszenie z zapomnienia kilku dalszych. 
Część z nich występuje również w kontynentalnej Europie, ale tutaj ciągle odkrywane są gatunki nowe dla Południowej i Środkowej Europy lub nawet opisywane nowe dla nauki gatunki w tym rodzaju (np. Blom 1997; BLOM \& LÜTH 2002; BLOM i in. 2006, 2015; KÖCKINGer i in. 2008; Ignatova i in. 2010; KiebaCher \& KÖCKINGer 2015; GuerRa i in. 2019). Dlatego też bogactwo gatunkowe oraz rozmieszczenie wielu gatunków w tej części kontynentu jest ciągle fragmentaryczne i wymaga dalszych badań.

Oprócz gatunków nowych dla Pasma Policy, w pracy zamieszczono nowe stanowiska dla 12 gatunków, które były dotychczas znane z jednego lub kilku stanowisk i przez to traktowane jako bardzo rzadkie lub rzadkie na tym obszarze (STEBeL i in. 2004). Znaleziska te potwierdzają dobrze znany fakt, że badania florystyczne stale mają głęboki sens poznawczy i ciągłe monitorowanie jakiegoś terenu dostarcza nowych danych chorologicznych, zwłaszcza dla rzadkich i zagrożonych gatunków, umożliwiając tym samym ocenę stopnia ich zagrożenia, zgodnie $\mathrm{z}$ aktualnie obowiązującymi i powszechnie akceptowanymi kategoriami IUCN.

Dzięki odkryciu 15 dalszych gatunków, przy jednoczesnym skreśleniu jednego gatunku (Tortula mucronifolia), flora mchów Pasma Policy liczy obecnie 278 gatunków i 5 odmian. W tym kontekście bardzo interesująco przedstawia się statystyka bogactwa florystycznego mchów w obrębie samego Beskidu Wysokiego. To największe w Beskidach Zachodnich pasmo obejmuje cztery mniejsze jednostki: Pasmo Babiogórskie składające się z Masywu Babiej Góry i Pasma Policy, Beskid Żywiecko-Orawski, czyli grupa Pilska i Wielkiej Raczy oraz Pogórze Orawsko-Jordanowskie, zwane inaczej Działami Orawskimi z Pasmem Podhalańskim. Jako całość Beskid Wysoki posiada najbogatszą florę mchów w Beskidach Zachodnich, liczącą 355 gatunków, 1 podgatunek i 11 odmian. W jego obrębie, najbogatszą florę mchów posiada masyw Babiej Góry - 280 gatunków (Stebel i in. 2018; Ellis i in. 2019a). Wyprzedza on tylko o dwa gatunki Pasmo Policy oraz Beskid Żywiecko-Orawski, czyli grupę Pilska i Wielkiej Raczy, w którym stwierdzono dotychczas 269 gatunków, 1 podgatunek i 5 odmian (A. Stebel, dane npbl.) i Pogórze Orawsko-Jordanowskie (Działy Orawskie z Pasmem Podhalańskim), z którego znanych jest 241 gatunków i 10 odmian (Stebel \& VonČina 2014). W Paśmie Policy znanych jest 5 gatunków, które nie występują w innych częściach Beskidu Wysokiego, a mianowicie Schistidium elegantulum, S. trichodon var. trichodon, Bucklandiella affinis, Syntrichia latifolia i Meesia uliginosa.

Gdyby rozpatrywać bogactwo florystyczne Beskidów Zachodnich w kontekście tych jednostek fizjograficznych, to całkiem niespodziewanie największa bioróżnorodność flory mchów występuje w Beskidzie Śląskim (304 gatunki + 3 odmiany) i Gorcach (286 gatunków +9 odmian). Dopiero trzecie miejsce w tym rankingu zajmuje masyw Babiej Góry (280 gatunków +1 podgatunek +7 odmian), który teoretycznie powinien mieć najbogatszą muskoflorę, chociażby z racji obecności w nim piętra alpejskiego, w którym występują liczne gatunki wysokogórskie, znane u nas tylko z Tatr. Tuż za tymi pasmami, na czwartym miejscu plasuje się Pasmo Policy (278 gatunków +5 odmian). Statystyka ta może jednak łatwo ulec zmianie, zwłaszcza po przeprowadzeniu dalszych szczegółowych badań terenowych na Babiej Górze, gdzie piętro alpejskie powinno dostarczyć znaleziska szeregu gatunków wysokogórskich. 
Podziękowania. Badania Ryszarda Ochyry i Katarzyny Biłyk były prowadzone w ramach zadań statutowych Instytutu Botaniki im. W. Szafera PAN w Krakowie, zaś Adama Stebla w ramach badań statutowych Katedry i Zakładu Botaniki Farmaceutycznej i Zielarstwa ŚUM: KNW-1-057/K/9/0. Dr Vítězslav Plášek z Uniwersytetu Ostrawskiego w Republice Czeskiej oznaczył niektóre okazy mchów z rodziny Orthotrichaceae oraz udostępnił zdjęcia wielu gatunków mchów, a dr James R. Shevock z Kalifornijskiej Akademii Nauk w San Francisco w U.S.A. zweryfikował język angielski w abstrakcie i streszczeniu za co autorzy im serdecznie dziękują. Autorzy pragną wyrazić też swoją wdzięczność mgr. Mirosławowi Szczepańskiemu z Gronowa koło Działdowa za informację o stanowisku Hookeria lucens w rezerwacie „Kamień nad Rzepedzią” w Beskidzie Niskim oraz mgr inż. Dorocie Bury z Nowosiółek Dydyńskich koło Fredropola za podanie informacji o niepublikowanym stanowisku na Pogórzu Przemyskim i szczegółowe dane odnośnie do występowania tego gatunku w projektowanym Turnickim Parku Narodowym w Beskidach Wschodnich, a także mgr. Marianowi Wysockiemu z Instytutu Botaniki im. W. Szafera PAN w Krakowie za pomoc techniczną w opracowaniu mapek rozmieszczenia.

\section{LITERATURA}

AlEXANDrowicz Z. (red.). 1989. Ochrona przyrody i krajobrazu Karpat Polskich. - Studia Naturae, Seria B - Wydawnictwa Popularnonaukowe 33: 1-241 + 16 tablic + 11 map folio.

ANONIM. 1998. Rozporządzenie Ministra Ochrony Środowiska, Zasobów Naturalnych i Leśnictwa z dnia 21 grudnia 1998 r. w sprawie uznania za rezerwat przyrody (Dz. U. z 1998 r. Nr 161, poz. 1095).

ANonim. 2014. Rozporządzenie Ministra Środowiska z dnia 9 października 2014 r. w sprawie ochrony gatunkowej roślin (Dz. U. Rzeczypospolitej Polskiej, Warszawa, dnia 16 października 2014 r., poz. 1409).

ARMATA L. 2006. New records of rare and endangered mosses from the Bieszczady Zachodnie Range and the Carpathian Foothills. - Annales Universitatis Mariae Curie-Skłodowska, Sectio C Biologia 61: 131-139.

ARMATA L. 2011. Invasive tendencies of bryophytes in the flora of the Jasło-Sanok Basin (Carpathian Foothills, SE Poland). - W: A. Stebel \& R. Ochyra (red.), Chorological studies on Polish Carpathians bryophytes, s. 223-232. Sorus, Poznań.

Barć A., FoJcik B. \& Brzustewicz M. 2007. Nowe stanowisko Hookeria lucens (Musci, Hookeriaceae) w Beskidzie Małym (Karpaty Zachodnie). - Fragmenta Floristica et Geobotanica Series Polonica 14(2): 19-21.

Bednarek-Ochyra H. 1991. Heterocladium heteropterum (Musci, Thuidiaceae) in Poland. - Fragmenta Floristica et Geobotanica 35(1-2): 77-81.

BednareK-Ochyra H. 1995. Rodzaj Racomitrium (Musci, Grimmiaceae) w Polsce: taksonomia, ekologia i fitogeografia. - Fragmenta Floristica et Geobotanica Series Polonica 2: 3-307.

Bednarek-Ochyra H. \& Ochyra R. 1996. Distribution of Pleuridium palustre (Musci, Ditrichaceae) in Poland. - Fragmenta Floristica et Geobotanica 41(2): 815-819.

Bednarek-Ochyra H., Ochyra R. \& SzMajda P. 1990a. M. 269. Racomitrium affine (F.Weber \& D.Mohr) Lindb. - W: R. OCHYRA \& P. SZMAJDA (red.), Atlas of the geographical distribution of spore plants in Poland. Series V. Mosses (Musci), Part 6, s. 21-23 + 1 mapa. W. Szafer Institute of Botany, Polish Academy of Sciences, Kraków, Adam Mickiewicz University, Poznań.

Bednarek-Ochyra H., Ochyra R. \& Szmajda P. 1990b. M. 471. Heterocladium heteropterum (Hedw.) Schimp. - W: R. OChYRA \& P. SzMAJDA (red.), Atlas of the geographical distribution of spore plants in Poland. Series V. Mosses (Musci), Part 6, s. 31-34 + 1 mapa.W. Szafer Institute of Botany, Polish Academy of Sciences, Kraków \& Adam Mickiewicz University, Poznań.

BednareK-Ochyra H., Ochyra R. \& Szmajda P. 1994. M. 455. Thamnobryum alopecurum (Hedw.) Gang. - W: R. OCHYRA \& P. SZMAJDA (red.), Atlas of the geographical distribution of mosses in Poland. 
Series V. Mosses (Musci), Part 9, s. 27-35 + 1 mapa. W. Szafer Institute of Botany, Polish Academy of Sciences, Kraków \& Adam Mickiewicz University, Poznań.

Bednarek-Ochyra H., Ochyra R., SAwicki J. \& Szczecińska M. 2014. Bucklandiella seppeltii, a new species of Grimmiaceae from Australasia and its phylogenetic position based on molecular data. - Turkish Journal of Botany 38: 1214-1228.

Bednarek-Ochyra H., Sawicki J., Ochyra R., Szczecińska M. \& PlášEk V. 2015. Dilutineuron, a new moss genus of the subfamily Racomitrioideae (Grimmiaceae, Bryophyta). - Acta Musei Silesiae Scientiae Naturales 64(2): 163-168.

BLom H. H. 1996. A revision of the Schistidium apocarpum complex in Norway and Sweden. - Bryophytorum Bibliotheca 49: 1-333.

BLom H. H. 1997. An account on the genus Schistidium (Grimmiaceae) in two areas of the Swiss Alps. - Meylania 12: 27-29.

Bцом H. H. \& LÜth M. 2002. Schistidium spinosum, a new species from Europe and its relationship to S. liliputanum. - Lindbergia 27: 122-126.

Blom H. H., BeDNAREK-Ochyra H. \& OChyra R. 2015. Studies on Schistidium (Grimmiaceae, Bryophyta) in Europe, with particular reference to the Alps: I. A description of $S$. marginale sp. nov. - Phytotaxa 247(3): 210-218.

Blom H. H., Ignatova E. \& Afonina O. M. 2006. New records of Schistidium (Grimmiaceae, Musci) in Russia. - Arctoa 15: 187-194.

BRYLSKA B. 1991. Fissidens cristatus var. mucronatus (Musci, Fissidentaceae), zapomniany takson we florze mchów Polski. - Fragmenta Floristica et Geobotanica 35(1-2): 239-244.

BURY D. 2018. Mszaki: mchy i wątrobowce (Bryophyta, Marchantiophyta). - W: D. BoćKOwSKI (red.), Projektowany Turnicki Park Narodowy. Stan walorów przyrodniczych - 35 lat od pierwszego projektu parku narodowego na Pogórzu Przemyskim, s. 154-162. Fundacja Dziedzictwo Przyrodnicze, Nowosiółki Dydyńskie. http://przyrodnicze.org/v1/wp-content/uploads/2018/11/turnicki_monografia_03_10_2018_FINAL.pdf

CANo M. J., Werner O. \& Guerra J. 2005. A morphometric and molecular study in Tortula subulata complex (Pottiaceae, Bryophyta). - Botanical Journal of the Linnean Society 149: 333-350.

CHAŁUBIŃSKI T. 1886. Enumeratio muscorum frondosorum Tatrensium hucusque cognitorum. s. vii +207 + Tab. 1. Drukiem Emila Skiwskiego, Warszawa.

Dietzow L. 1938. Die Moose Altpreußens und ihre Standorte. s. 84. Buchdruckerei R. Leupold, Königsberg (Pr.).

Ellis L. T., Aleffi M., Baczzkiewicz A., Buczkowska K., Bambe B., Boiko M., Zagorodniuk N., Brusa G., Burghardt M., Calleja J. A., Mazimpaka V., Lara F., Fedosov V. E., Gremmen N. J. M., Homm T., Hugonnot V., Ignatova E. A., Klama H., Kučera J., Vicherová E., Lamkowski P., Lapshina E. D., Maksimov A. I., Maksimova T. A., Ochyra R., Plášek V., Pleskach L. Ya., Poponessi S., Venanzoni R., Pospelov I. N., Potemkin A. D., Kholod S. S., Sáez L., Skuchas Yu. V., Spitale D., Srivastava P., Omar I., Asthana A. K., Ştefănuţ S., Torzewski K., Virchenko V. M., WiERZGOŃ M. \& Wolski G. J. 2019a. New national and regional bryophyte records, 60. - Journal of Bryology 41(3): 285-299.

Ellis L. T., Aleffi M., Asthana A. K., Srivastava A., Bakalin V. A., Batan N., Özdemir T., Bednarek-Ochyra H., Borovichev E. A., Brugués M., Cano M. J., Chol S. S., De Beer D., Eckstein J., Erzberger P., Fedosov V. E., Ganeva A., Natcheva R., Garcia C. A., Sérgio C., Garilleti R., Albertos B., Puche F., Gücel S., Higuchi M., Hugonnot V., Hylander K., Kirmaci M., Aslan G., Koponen T., Lara F., Mazimpaka V., van Melick H., Müller F., Özenoglu Kiremit H., Papp B., Szurdoki E., Plášek V., Číhal L., van der Pluijm A., Poponessi S., Mariotti M. G., Reyniers J., 
Sabovluević M. S., Sawicki J., Smith V. R., Stebel A., Ştefănuţ S., Sun B.-Y., VÁŇa J. \& VenanZONI R. 2014. New national and regional bryophyte records, 40. - Journal of Bryology 36(3): 223-244.

Ellis L. T., Afonina O. M., Czernyadjeva I. V., Ivchenko T. G., Kholod S. S., Kotkova V. M., Kuzmina E. Yu., Potemkin A. D., Sergeeva Yu. M., Asthana A. K., Gupta D., Sahu V., Srivastava S., Bakalin V. A., Bednarek-Ochyra H., Campisi P., Dia M. G., Choi S. S., Dagnino D., Minuto L., Turcato C., Drapela P., Dugarova O. D., Tubanova D. Ya., Enroth J., Koponen T., Klama H., ErdaĞ A., Kirmaci M., Fedosov V. E., Hodgetts N. G., Holyoak D. T., JukonienĖ I., Konstantinova N. A., Savchenko A. N., Vilnet A. A., Krival E. A., Kürschner H., Lapshina E. D., Larrain J., Ma W. Z., Maksimov A. I., Marino M. L., Müller F., Pande N., Park S. J., Sun B.-Y., Pivoras A., Plášek V., Puglisi M., Sciandrello S., Rajian N. J., Suleiman M., SchäferVerwimp A., Shevock J. R., Spitale D., Stebel A., Taha M. A. \& Porley R. D. 2019b. New national and regional bryophyte records, 61. - Journal of Bryology 41(4): 364-384.

FoJCIK B. 2011a. Mchy Wyżyny Krakowsko-Częstochowskiej w obliczu antropogenicznych przemian szaty roślinnej. s. 232. Wydawnictwo Uniwersytetu Śląskiego, Katowice.

FoJCIK B. 2011b. Distribution atlas of mosses of the Cracow-Częstochowa Upland. s. 173. Centrum Dziedzictwa Przyrody Górnego Śląska, Katowice.

Fudali E., Stebel A., Rusińska A., Klama H., Żarnowiec J., Pisarek W., Duda-Klimaszewski S., StANiaszeK M. \& WierzCholsKa S. 2003. Materiały do brioflory wschodnich Karkonoszy. - Annales Silesiae 32: 19-32.

Guerra J., JimÉnez-Martínez J. F., CANo M. J., Alonso M. \& Gallego M. T. 2019. Schistidium convergens (Grimmiaceae, Bryophyta), a new species from southern Spain and Morocco. - Nova Hedwigia 109(1-2): 65-80.

Ignatova E. A., Blom H. H., Goryunov D. V. \& Milyutina I. A. 2010. On the genus Schistidium in Russia. - Arctoa 19: 195-233.

Karczmarz K. 1979. Mszaki Pasma Bukowicy w Beskidzie Niskim. - Fragmenta Floristica et Geobotanica 25(1): 191-206.

KARCZMARZ K. 1987. Flora mszaków Beskidu Niskiego. - Annales Universitatis Mariae Curie-Skłodowska, Sectio C Biologia 42: 111-135.

KarczMARZ K. \& Kuc M. 1962. Mchy wschodniej części Wyżyny Lubelskiej. - Fragmenta Floristica et Geobotanica 8(4): 483-508.

KIEBACHER T. \& KöCKINGER H. 2015. Ein weitere Fund von Schistidium sordidum I. Hagen in der Schweiz: Anmerkungen zu Taxonomie und Verbreitung der Art. - Meylania 55: 12-15.

Klama H. \& OchYRa R. 2018. Hookeria lucens (Bryophyta, Hookeriaceae) - nowy gatunek we florze mchów Pasma Policy (Beskidy Zachodnie). - Fragmenta Floristica et Geobotanica Polonica 25(2): 298-302.

KONDRACKI J. 2014. Geografia regionalna Polski. Wyd. 3. s. $441+24$ s. nienumerowane +1 wkładka (mapa). Wydawnictwo Naukowe PWN, Warszawa.

Köckinger H., Suanjak M., Schriebl A. \& Schröck C. 2008. Die Moose Kärntens. - W: Sonderreihe Natur Kärnten, Band 4. s. 319. Verlag des Naturwissenschaftlichen Vereins für Kärnten, Klagenfurt.

KRUPA J. 1882. Zapiski bryjologiczne. - Sprawozdanie Komisyi Fizyjograficznéj 16: 170-204.

KRUPA J. 1888. Zapiski bryjologiczne z Tatr i Przedtatrza. - Sprawozdanie Komisyi Fizyjograficznej 21: 65-94.

Kuc M. 1962. Mchy zachodniej części Wyżyny Lubelskiej. - Fragmenta Floristica et Geobotanica 8(1): $23-55$.

Kuc M. 1963. Materiały briologiczne z Roztocza. - Fragmenta Floristica et Geobotanica 9(1): 97-116.

KuC M. 1964. Briogeografia wyżyn południowych Polski. - Monographiae Botanicae 17: 1-212. 
Lara F., Garilleti R., Goffinet B., Draper I., Medina R., Vigalondo B. \& Mazimpaka V. 2016. Lewinskya, a new genus to accommodate the phaneroporous and monoicous taxa of Orthotrichum (Bryophyta, Orthotrichaceae). - Cryptogamie, Bryologie 37(4): 361-382.

Limpricht K. G. 1874. Über die Moos-Vegetation der Babiagora. - Jahresbericht der Schlesischen Gesellschaft für Vaterländische Cultur 51: 77-78.

Limpricht K. G. 1876. Laubmoose. - W: F. CoHN (red.), Kryptogamen-Flora von Schlesien. Band 1, s. 27-224. J. U. Kern's Verlag (Max Müller), Breslau.

Limpricht K. G. 1890 [„,1885-1889”]. Die Laubmoose Deutschlands, Oesterreichs und der Schweiz. - W: Dr L. Rabenhorst's Kryptogamen-Flora von Deutschland, Oesterreich und der Schweiz. 2 Aufl. Band 4(1): Bryineae (Stegocarpae [Acrocarpae, Pleurocarpae excl. Hypnaceae]). s. xi + 836. Verlag von Eduard Kummer, Leipzig.

LisowsKi S. 1956a. Bryotheca Polonica. Musci Montis Śnieżnik Kłodzki (Sudeti). Fasc. XIV. Nr 376-400. s. 7. Academia Scientiarum Poloniae, Posnaniae.

LisowsKI S. 1956b. Bryotheca Polonica. Musci in montibus "Bieszczady Zachodnie" collecti. Fasc. IX. Nr 251-275. s. 9. Academia Scientiarum Poloniae, Posnaniae.

Lisowski S. 1956c. Mchy Bieszczadów Zachodnich. - Prace Komisji Biologicznej, Poznańskie Towarzystwo Przyjaciół Nauk, Wydział Matematyczno-Przyrodniczy 17(3): 107-201 [1-95].

Lisowski S. 1959. Materiały do brioflory Tatr. - Prace Komisji Biologicznej, Poznańskie Towarzystwo Przyjaciół Nauk, Wydział Matematyczno-Przyrodniczy 21(2): 21-149 [1-129] + 2 mapy na wklejce.

LisowsKi S. 1965. Matériaux bryologiques des Tatras. - Bulletin de la Société des Amis des Sciences et des Lettres de Poznań, Série D, 6: 123-146.

LisowsKi S. \& KoRnaŚ J. 1966. Mchy Gorców. - Fragmenta Floristica et Geobotanica 12(1): 41-114.

MamcZarz H. 1977. Brioflora i zbiorowiska mszaków Beskidu Sądeckiego. Część 1. Brioflora Beskidu Sądeckiego. - Monographiae Botanicae 54: 1-158.

MiLdE J. 1869. Bryologia silesiaca. Laubmoos-Flora von Nord- und Mittel-Deutschland unter besonderer Berücksichtigung Schlesiens und mit Hinzunahme der Floren von Jütland, Holland, der Rheinpflaz, von Baden, Franken, Böhmen, Mähren und der Umgegend von München. s. ix + 410. Arthur Felix, Leipzig.

OCHYRa R. 1984 [„,1982”]. Mchy Skalic Nowotarskich i Spiskich (Pieniński Pas Skałkowy). - Fragmenta Floristica et Geobotanica 28(3): 419-488.

Ochyra R. \& CisŁo G. 1999. Mchy w zielniku Tytusa Chałubińskiego w Muzeum Tatrzańskim w Zakopanem. - Polish Botanical Studies, Guidebook Series 22: 1-178.

Ochyra R. \& Stebel A. 2008. Mosses of the Małe Pieniny Range (Polish Western Carpathians). - W: A. SteBEL \& R. OCHYRA (red.), Bryophytes of the Polish Carpathians, s. 75-141. Sorus, Poznań.

Ochyra R. \& SzMajda P. 1981. La cartographie bryologique en Pologne. - W: J. SzWeYKowsKi (red.), New perspectives in bryotaxonomy and bryogeography. Second Bryological Meeting, Poznań, June $26^{\text {th }}-29^{\text {th }}, 1980$, s. $105-110$. Wydawnictwo Naukowe Uniwersytetu im. Adama Mickiewicza [Seria Biologia Nr 20], Poznań.

Ochyra R. \& Szmajda P. 1983. M. 409. Amphidium lapponicum (Hedw.) B. S. G. - W: J. Szweykowski $\&$ T. WoJTERsKi (red.), Atlas of geographical distribution of spore-plants in Poland. Series V. Mosses (Musci). Part 1, s. $17+1$ mapa. Państwowe Wydawnictwo Naukowe, Warszawa - Poznań.

Ochyra R., Bednarek-Ochyra H. \& SzMAJdA P. 1990. M. 267. Racomitrium fasciculare (Hedw.) Brid. - W: R. OChYRA \& P. SZMAJDA (red.), Atlas of the geographical distribution of spore plants in Poland. Series V. Mosses (Musci), Part 5, s. 23-27 + 1 mapa.W. Szafer Institute of Botany, Polish Academy of Sciences, Kraków \& Adam Mickiewicz University, Poznań. 
Ochyra R., Żarnowiec J. \& Bednarek-Ochyra H. 2003. Census catalogue of Polish mosses. s. 372. W. Szafer Institute of Botany, Polish Academy of Sciences, Kraków.

Ochyra R., Szmajda P., Bednarek H. \& Bocheński W. 1988a. M. 386. Meesia uliginosa Hedw. - W: Z. TOBolewski \& T. WoJTERski (red.), Atlas of [the] geographical distribution of spore plants in Poland. Series V. Mosses (Musci), Part 3, s. 11-13 + 1 mapa folio. Państwowe Wydawnictwo Naukowe, Warszawa - Poznań.

Ochyra R., SzMajda P., BocheŃski W. \& KarczMarz K. 1988b. M. 452. Neckera complanata (Hedw.) Hueb. - W: Z. Tobolewski \& T. WoJTERski (red.), Atlas of [the] geographical distribution of spore plants in Poland. Series V. Mosses (Musci), Part 4, s. 33-39 + 1 mapa folio. Państwowe Wydawnictwo Naukowe, Warszawa - Poznań.

Ochyra R., Szmajda P., Bocheński W. \& Karczmarz K. 1988c. M. 453. Neckera webbiana (Mont.) Duell. - W: Z. Tobolewski \& T. WoJTERSKi (red.), Atlas of [the] geographical distribution of spore plants in Poland. Series V. Mosses (Musci), Part 4, s. 41-43 + 1 mapa folio. Państwowe Wydawnictwo Naukowe, Warszawa - Poznań.

PaCiOReK T. 2015. 12. Hookeria lucens (Hedw.) Sm. [in the Gorce]. - W: P. GóRsKI \& A. RusińsKa (red.), New distributional data on bryophytes of Poland, 2. - Steciana 19(2): 59.

Pasierbek T., Holeksa J., Wika S. \& Wilczek Z. 2004. Zbiorowiska leśne i zaroślowe rezerwatu „Na Policy im. Prof. Z. Klemensiewicza” w Beskidzie Żywieckim. - Parki Narodowe i Rezerwaty Przyrody 23(1): 37-59.

PlášEK V. \& STEBEL A. 2002. Bryophytes of the Čantoryjský hřbet range (Czantoria range) and its foothills (Western Carpathians - Czech Republic, Poland). - Časopis Slezského Zemského Muzea, Série A - Vědy Př́rodní 51: 1-87.

PlášEK V., SAWICKI J. \& OCHYRA R. 2016. Are Orthotrichum and Dorcadion (Orthotrichaceae, Bryophyta) heterotypic generic names? - Acta Musei Silesiae Scientiae Naturales 65(3): 193-202.

PlášEk V., SAwicki J., Ochyra R., Szczecińska M. \& Kulik T. 2015. New taxonomical arrangement of the traditionally conceived genera Orthotrichum and Ulota (Orthotrichaceae, Bryophyta). - Acta Musei Silesiae Scientiae Naturales 64(2): 169-174.

Rehmann A. 1865. Versuch einer Aufzählung der Laubmoose von Westgalizien. - Verhandlungen der Kaiserlich-Königlichen Zoologisch.-Botanischen Gesellschaft in Wien 15: 461-484.

Rehman A. 1869. Zapisek botaniczny znad brzegów Popradu. - Sprawozdanie Komisyi Fizyjograficznéj 3: $56-66$.

Rusińska A. 1995. New locality of Campylopus flexuosus (Musci, Dicranaceae) in West Pomerania and a review of its distribution in Poland. - Fragmenta Floristica et Geobotanica 40(1): 305-309.

Sawicki J., Szczecińska M., Bednarek-Ochyra H. \& Ochyra R. 2015. Mitochondrial phylogenomics supports splitting the traditionally conceived genus Racomitrium (Bryophyta: Grimmiaceae). - Nova Hedwigia 100: 293-317.

Sawicki J., Plášek V., Ochyra R., Szczecińska M., Ślipiko M., Myszczyński K. \& Kulik T. 2017. Mitogenomic analyses support the recent division of the genus Orthotrichum (Orthotrichaceae, Bryophyta). - Scientific Reports 7: Article number 4408. https://doi.org/10.1038/s41598-017-04833-z.

Smoczyк M. 2017. Nowe dane do rozmieszczenia krzywoszczeci pogiętej Campylopus flexuosus (Hedw.) Brid. (Bryophyta) w Sudetach. - Przyroda Sudetów 20: 73-78.

SteBEL A. 1999. Nowe stanowiska rzadkich i zagrożonych mchów w Beskidach Zachodnich i na Pogórzu Zachodniobeskidzkim (Karpaty Zachodnie). - Fragmenta Floristica et Geobotanica Series Polonica 6: 203-210.

Stebel A. 2000. Materiały do flory mchów masywu Babiej Góry (Karpaty Zachodnie). - Parki Narodowe i Rezerwaty Przyrody 19(3): 43-54. 
Stebel A. 2003a. Musci macroregioni meridionali Poloniae exsiccati. Fasciculus XXXVIII (No. 1151-1200). s. 12. Medical University of Silesia in Katowice, Katowice.

STEBEL A. 2003b. Mchy rezerwatu przyrody „Stok Szyndzielni” w Beskidzie Śląskim (Karpaty Zachodnie). - Natura Silesiae Superioris 7: 41-48.

STEBEL A. 2003c. Mszaki rezerwatów przyrody „Mokrzyk” i „Skarpa Wiślicka” na Pogórzu Śląskim. - Archiwum Ochrony Środowiska 29: 99-110.

Stebel A. 2004a. A contribution to the bryoflora of the western part of the Carparthian Foothills. - W: A. Stebel \& R. Ochyra (red.), Bryological studies in the Western Carpathians, s. 135-145. Sorus, Poznań.

Stebel A. 2004b. Mosses of the Czantoria Nature Reserve in the Beskid Śląski Range (Western Carpathians). - W: A. STEBel \& R. OchYRA (red.), Bryological studies in the Western Carpathians, s. 119-126. Sorus, Poznań.

Stebel A. 2004c. A contribution to the moss flora of the Gorce (Western Carparthians). - W: A. STEBEL \& R. OCHYRA (red.), Bryological studies in the Western Carpathians, s. 127-134. Sorus, Poznań.

STEBEL A. 2004d. Mchy rezerwatu przyrody „Kuźnie” w Beskidzie Śląskim (Karpaty Zachodnie). - Archiwum Ochrony Środowiska 30(1): 133-142.

Stebel A. 2004e. Mchy Babiej Góry. - W: B. W. WoŁoszyn, A. Jaworski \& J. SzwagrzyK (red.), Babiogórski Park Narodowy. Monografia przyrodnicza, s. 357-378. Komitet Ochrony Przyrody PAN \& Babiogórski Park Narodowy, Kraków.

Stebel A. 2006a. The mosses of the Beskidy Zachodnie as a paradigm of biological and environmental changes in the flora of the Polish Western Carpathians. Habilitation Thesis No. 17/2006. s. 347. Medical University of Silesia in Katowice, Katowice - Poznań.

Stebel A. 2006b. Stanowisko nibybielistki Sautera Paraleucobryum sauteri (Bryopsida) w Babiogórskim Parku Narodowym. - Chrońmy Przyrodę Ojczystą 62(4): 99-102.

SteBel A. 2006c. Changes in the epiphytic moss flora of the Beskidy Zachodnie Mountains (Carpathians, Poland). - W: P. KoČÁReK, V. PláŠEK \& K. MalachovÁ (red.), Environmental changes and biological assessments III. - Scripta Facultatis Rerum Naturalium Universitatis Ostraviensis 163: 101-107.

SteBel A. 2006d. Mchy rezerwatu przyrody „Gawroniec” w Beskidzie Wysokim (Karpaty Zachodnie). - Natura Silesiae Superioris 9: 33-40.

Stebel A. 2007. Nowe dane do rozmieszczenia krzywoszczeci pogiętej Campylopus flexuosus (Hedw.) Brid. (Bryopsida) w Polsce. - Chrońmy Przyrodę Ojczystą 63(2): 93-98.

SteBEl A. 2008. Mosses of the Kotlina Żywiecka basin (Western Carpathians). - W: A. STEBEL \& R. OChYRA (red.), Bryophytes of the Polish Carpathians, s. 11-74. Sorus, Poznań.

SteBEL A. 2009. Mech pędzliczek szerokolistny Syntrichia latifolia (Hartm.) Huebener w Karpatach Polskich i problemy jego ochrony. - Chrońmy Przyrodę Ojczystą 65(4): 293-298.

Stebel A. 2010a. Mosses of the Beskid Mały Range (Western Carpathians). - Centrum Dziedzictwa Przyrody Górnego Śląska, Materiały Opracowania 11: 1-144.

SteBel A. 2010b. Wpływ zbiorników zaporowych na Dunajcu w Pieninach na florę mchów tego regionu. - W: R. Soja, S. KNUTElSki \& J. BodZiarCZYK (red.), Pieniny - zapora - zmiany, s. 161-171. Pieniński Park Narodowy, Krościenko nad Dunajcem.

SteBel A. 2011. Kilka nowych gatunków mchów z Magurskiego Parku Narodowego (Beskid Niski, Karpaty Zachodnie). - Roczniki Bieszczadzkie 19: 141-147.

Stebel A. 2015a. Contribution to the moss flora of the Poprad Landscape Park (Western Carpathians, Poland). - Nature Journal 48: 58-69.

Stebel A. 2015b. Contribution to the bryoflora of the Wiśnickie Foothills (Western Carpathians, Poland). - Acta Musei Silesiae, Scientiae Naturales 64(3): 131-139. 
Stebel A. 2016a. Contribution to the bryoflora of the Rożnowskie Foothills (Western Carpathians, Poland). - Fragmenta Naturae 49: 1-13.

Stebel A. 2016b. Contribution to the moss flora of the Magura National Park (Western Carpathians, Poland). - Fragmenta Naturae 49: 14-26.

SteBel A. 2017. Notatki briologiczne z okolic Rzyk (Beskid Mały, Karpaty Zachodnie). - Fragmenta Naturae 50: 10-17.

Stebel A. \& BednareK-Ochyra H. 2004. The moss genus Codriophorus (Bryopsida, Grimmiaceae) in the Polish Carpathians. - W: A. Stebel \& R. OchYRA (red.), Bryological studies in the Western Carpathians, s. 45-61. Sorus, Poznań.

Stebel A. \& CZarnota P. 2012. Wykaz mchów pasma Gorców w polskich Karpatach Zachodnich. - Ochrona Beskidów Zachodnich 7: 32-47.

SteBel A. \& GóRski P. 2004. Spreading of Oligotrichum hercynicum (Musci, Polytrichaceae) in the Polish part of the Carpathians. - Časopis Slezského Zemského Muzea, Série A - Vědy Přírodní 53: 97-108.

Stebel A. \& Krajewski Ł. 2020. Nowe i rzadkie gatunki mszaków we florze województwa śląskiego. - Fragmenta Naturae 53: 27-58.

Stebel A. \& Ochyra R. 2000. Flora mchów Magurskiego Parku Narodowego. - Fragmenta Floristica et Geobotanica Polonica 7: 229-263.

Stebel A. \& Stebel A. M. 1998. Materiały do brioflory Beskidu Małego i północnej części Kotliny Żywieckiej (Karpaty Zachodnie). - Fragmenta Floristica et Geobotanica Series Polonica 5: 217-236.

Stebel A. \& VončInA G. 2014. Bryophyte diversity in the flora of the Orawsko-Jordanowskie Foothills (Polish Western Carpathians). s. 127. Muzeum Tatrzańskie, Zakopane.

Stebel A. \& VončIna G. 2017. Contribution to the bryoflora of the Ciężkowice Foothills (Western Carpathians, Poland). - Acta Musei Silesiae, Scientiae Naturales 66(2): 121-135.

Stebel A. \& Vončina G. 2018. The moss Thamnobryum neckeroides (Neckeraceae) in Poland. - Herzogia 31(1): 304-310.

Stebel A. \& WiLCZeK Z. 2000. Szata roślinna rezerwatu przyrody „Grapa” w Kotlinie Żywieckiej (Karpaty Zachodnie). - Ochrona Przyrody 57: 59-71.

Stebel A. \& Zubel R. 2018. Kolekcja mszaków A. Grawa w zielniku Zakładu Botaniki i Mykologii Uniwersytetu Marii Curie-Skłodowskiej w Lublinie. - Fragmenta Naturae 51: 6-24.

Stebel A. \& Żarnowiec J. 2010. Materiały do flory mchów Bieszczadów Zachodnich (Karpaty Wschodnie). - Roczniki Bieszczadzkie 18: 134-156.

Stebel A. \& Żarnowiec J. 2017. The moss genus Zygodon (Orthotrichaceae) in Poland - distribution, ecological preferences and threats. - Cryptogamie, Bryologie 38(3): 231-251.

Stebel A., Ochyra R. \& Vončina G. 2010. Mosses of the Pieniny Range (Polish Western Carpathians). s. 114. Sorus, Poznań.

Stebel A., Krause R. \& SMieja A. 2016. Nowe stanowiska mchów we florze Gorców (Karpaty Zachodnie). - Fragmenta Floristica et Geobotanica Polonica 23(1): 175-177.

Stebel A., Żarnowiec J. \& Vončina G. 2018. Charakterystyka flory mchów masywu Babiej Góry. - W: J. Holeksa \& J. SzWAgRzYK (red.), Monografie Babiogórskie. Rośliny Babiej Góry, s. 31-61. Babiogórski Park Narodowy, Wrocław - Zawoja.

Stebel A., Ochyra R., Stuchlik L. \& Parusel J. 2004. Mosses of the Polica Range (Polish Western Carpathians). s. 121. Sorus, Poznań.

Stebel A., Paciorek T., Vončina G., Krause R., Smieja A. \& Piwowarski B. 2017. Nowe dane do rozmieszczenia chronionych, zagrożonych i rzadkich mchów w Gorcach (Karpaty Zachodnie). - Ochrona Beskidów Zachodnich 4: 7-25. 
Stebel A., Ochyra R., Bednarek-Ochyra H., Stachnowicz W., Krause R., Zubel R. \& RusińSKA A. 2004. Hookeria lucens (Bryopsida, Hookeriaceae) in the Polish Carpathians. - W: A. SteBeL \& R. OchYra (red.), Bryological studies in the Western Carpathians, s. 63-70. Sorus, Poznań.

Stebel A., Zubel R., Vončina G., Fudali E., Wierzcholska S., Staniaszek-KiK M., Fojcik B., RusińSKA A. \& SZCZEPAŃSKI M. 2016. Różnorodność gatunkowa mszaków rezerwatu leśnego „Chwaniów” (Góry Sanocko-Turczańskie, Karpaty Wschodnie). - Acta Botanica Silesiaca 12: 85-100.

Stuchlik L. 1968a. Zbiorowiska leśne i zaroślowe pasma Policy w Karpatach Zachodnich. - Fragmenta Floristica et Geobotanica 14(4): 441-484.

StUCHLIK L. 1968b. Zbiorowiska ziołoroślowe i źródliskowe pasma Policy w Karpatach Zachodnich. - Fragmenta Floristica et Geobotanica 14(4): 485-484 + tablice 1-6, 8 na wkładkach.

Stuchlikowa B. 1967. Zbiorowiska łąkowe pasma Policy w Karpatach Zachodnich. - Fragmenta Floristica et Geobotanica 13(3): 357-402.

StUChlikowa B. \& STUChLIK L. 1962. Geobotaniczna charakterystyka pasma Policy w Karpatach Zachodnich. - Fragmenta Floristica et Geobotanica 8(3): 229-396 + ryc. 22-30 na wkładkach.

SzAFRAN B. 1956. Zapiski bryologiczne z Karpat Zachodnich (Beskidy, Tatry, Pieniny). - Fragmenta Floristica et Geobotanica 2(1): 143-167.

SzAFran B. 1957 [„,1958”]. Mchy (Musci). - W: Flora polska. Rośliny zarodnikowe Polski i ziem ościennych. Tom 1. s. 449. Państwowe Wydawnictwo Naukowe, Warszawa.

SzAFrAn B. 1965. Mchy Beskidu Śląskiego i Małego. - Fragmenta Floristica et Geobotanica 11(4): 614-628.

VončInA G. 2015. 12. Hookeria lucens (Hedw.) Sm. [in the Beskid Niski]. - W: P. GóRSKI \& A. RusińSKA (red.), New distributional data on bryophytes of Poland, 2. - Steciana 19(2): 59.

VončInA G. 2019. 20. Zygodon dentatus (Limpr.) Karttunen [in the Spiskie Klippen]. - W: P. GóRSKI \& A. RusińsKa (red.), New distributional data on bryophytes of Poland and Slovakia, 17. - Steciana 23(1): 25. doi: $10.12657 /$ steciana.023.002

Vončina G. \& Stebel A. 2016. Materiały do flory mchów (Bryophyta) Pienińskiego Pasa Skałkowego (Karpaty Zachodnie). - Pieniny - Przyroda i Człowiek 14: 79-89.

WACŁAWSKA Z. 1957. Mchy dorzecza górnego Wisłoku. - Fragmenta Floristica et Geobotanica 3(1): 93-113.

WiLCZeK R. 1936. Mchy zespołów leśnych Pogórza Cieszyńskiego. - Prace Biologiczne Śląskie 1: 81-112.

Zubel R., Danylkiv I., Rabyk I., Lobaczevs'Ka O. \& Soroka M. 2015. Bryophytes of the Roztocze region (Poland and Ukraine). A checklist of liverworts and mosses. s. 146. Towarzystwo Wydawnictw Naukowych Libropolis, Lublin.

ŻMUDA A. 1912. Zapiski bryologiczne z powiatu Wielickiego. - Kosmos (Lwów) 37(1-3): 109-117.

ŻARnOwIEC J. \& STEBel A. 2016. Gatunki chronione we florze mchów polskich Bieszczadów Zachodnich (Karpaty Wschodnie). - Roczniki Bieszczadzkie 24: 29-45.

Żarnowiec J., Stebel A. \& Ochyra R. 2004. Threatened moss species in the Polish Carpathians in the light of a new red-list of mosses in Poland. - W: A. STEBel \& R. OCHYRA (red.), Bryological studies in the Western Carpathians, s. 9-28. Sorus, Poznań.

\section{SUMMARY}

The Polica Range is an outstanding, sharply delimited physiographic unit in the Polish Western Carpathians, whose name comes from the highest peak - Mount Polica - reaching an altitude of $1369 \mathrm{~m}$ a.s.l. According to the latest geographical regionalisation of Poland (KONDRACKI 2014), it constitutes the eastern part of the Babia Góra Range and they together belong to the Beskid Wysoki Range, which is also known as the Beskid Żywiecki Range (Fig. 1). The Polica Range begins at the Krowiarki Pass, which separates it 
from the Babia Góra Range, from where its main ridge runs north-east ending in the valley of the Skawa River near Osielec (Fig. 2). Apart from Mount Polica, the range reaches its highest elevations at the summits of Czyrniec, also bearing another name Syhlec - $1318 \mathrm{~m}$ a.s.l., Kiczorka - $1298 \mathrm{~m}$ a.s.l. and Okraglica - 1239 m a.s.l. North-western slopes of the Polica Range descend to the valley of the Skawica River, in which two large villages of Zawoja (Fig. 3) and Skawica are located. The Baltic-Black Sea watershed runs through the south-western part of the Polica Range (KONDRACKI 2014). The Bystrzanka Stream, which is a tributary of the Skawa River and flows through the village of Sidzina in its valley at the foot of the south-eastern slopes of the range belongs to the Baltic Sea catchment. On the other hand, the Zubrzyca Stream and its tributaries, which in turn flows into the Black Orava River already belongs to the Black Sea catchment. In the summit parts of the northern slopes of Mount Polica "Professor Zenon Klemensiewicz Nature Reserve on Polica" was established in 1972 (AlEXANDrowicZ 1989), which is dominated by well preserved fragments of the Plagiothecio-Piceetum spruce forest (PASIERBEK et al. 2004).

Intensive field studies on the mosses of the Polica Range were conducted in the 1960s by Marian KuC and in the late 1970s by Ryszard OCHYRA. Their results were published only in 2004 in the form of a local flora, in which 264 species and 5 varieties have been recorded from this area (STEBEL et al. 2004). Field research carried out by the authors in the Polica Range in the last two years, as well as critical re-examination of some previously collected specimens led to the discovery of a number of moss species which proved to be new to the study area or were known only from individual sites. To date, only the most interesting of these finds devoted to Hookeria lucens (Hedw.) Sm. has been published (KLama \& OchYRA 2018).

The present study summarises information about 31 moss species recorded in the Polica Range after 2004. Of these, 15 species represent new records for this mountain range, whilst 16 species have so far been considered to be very rare or rare in this area, being known from only 1-6 localities.

The following species are new additions to the moss flora of the Polica Range. Species found for the first time in the Beskidy Zachodnie mountains are marked with an asterisk (*).

Ditrichum lineare - it was found at three localities (Fig. 4A). In the Polish Carpathians this species is rare and widely scattered and until recently it was known only from the Tatra Mountains in the Western Carpathians and the Bieszczady Zachodnie Range in the Eastern Carpathians. In recent years, it was found in the Pogórze Orawsko-Jordanowskie, as well as in the Beskid Mały and the Beskid Makowski (Fig. 5A).

Ditrichum pusillum - it was found at two locations (Fig. 4B). The species is very rare throughout Poland, with the main centre of occurrence in the southern highlands and, additionally, it is known, among others, from the Pojezierze Iławskie and the Pojezierze Chełmińsko-Dobrzyńskie Lakelands in the north of the country and the Kotlina Oświęcimska Basin (Podgórze Wilamowickie Foothills). In the Polish Carpathians, it was collected in the Tatra, the Kotlina Orawsko-Nowotarska Basin, the Skalice Spiskie Klippen, the Pogórze Wielickie and the Pogórze Spisko-Gubałowskie Foothills, the Beskid Śląski and the Beskid Sądecki in the Beskidy Zachodnie, as well as the Bieszczady Zachodnie (Fig. 5B). Thus, the records of D. pusillum in the Polica Range are the third occurrence of this species in the Beskidy Zachodnie.

Campylopus flexuosus - it was found at a single location (Fig. 4C). Even a quarter of a century ago, this species was considered to be very rare in Poland (RUSIŃSKA 1995). This was the reason for placing it on the Polish red list of endangered mosses (ŻARNOwIEC et al. 2004), as a result of which it was subsequently included in the list of species subject to partial protection in the country (ANONIM 2014). However, since the end of the 1990s, this species clearly began to spread in Poland, often occurring in great abundance in anthropogenic habitats, such as roadside embankments and banks and spruce and pine woodlands (Stebel 2007; Smoczyk 2017). In the Polish Carpathians, C. flexuosus is currently known from many sites, both in the Carpathian Foothills (Pogórze Wiśnickie, Pogórze Rożnowskie, Pogórze Ciężkowickie and Pogórze Dynowskie Foothills), as well as in the Beskidy Zachodnie (Beskid Śląski, Beskid Mały, Beskid Makowski, Beskid Wysoki, Kotlina Żywiecka) and the Beskid Niski Range in the Beskidy Środkowe (Fig. 5C), where it is generally rare, but with a clear tendency to spread.

Schistidium elegantulum - it was found at three localities (Fig. 4D). The geographical distribution of this species in Poland is very poorly understood, since this genus has not yet been critically revised in our country. So far, it has most often been recorded in the Pieniny Klippen Belt, but it was also reported from the Beskid Śląski and the Kotlina Oświęcimska, as well as from the Puszcza Romincka forest in the north of the country. 
Schistidium lancifolium - it was found at a single site (Fig. 4E). In Poland, it is known almost exclusively from the Western Carpathians (Fig. 6B). It was most often recorded in the Małe Pieniny and the Pieniny and occasionally in various ranges of the Beskidy Zachodnie (Beskid Śląski, Beskid Mały, Beskid Wysoki, Pogórze Orawsko-Jordanowskie) and, recently, it was also found in the Bieszczady Zachodnie. In the Sudetes, it is known only from the Śnieżnik Kłodzki massif.

"Schistidium trichodon var. trichodon - it was discovered at five localities (Fig. 4F). It is a montane species, but its distribution in Poland is not well known. To date, this species was recorded from the Bieszczady Zachodnie in the Polish Eastern Carpathians and from the Tatra, Małe Pieniny and Pieniny (Fig. 6C). In the Beskidy Zachodnie, this species has so far been found only once in the Beskid Śląski, where it occurs only as a separate variety - var. nutans H.H.Blom which is also known to occur in the Tatra, Małe Pieniny and Pojezierze Mazurskie lakeland in the north of the country. The populations from the Polica Range represent the type variety of this species and it is recorded for the first time from the Beskidy Zachodnie.

Dilutineuron fasciculare - it was found at a single locality (Fig. 7A). In Poland, it is a montane saxicolous moss, quite frequent in some ranges of the Sudetes and the Tatra. Outside the Tatra, it is very rare in other parts of the Polish Carpathians (Fig. 8A) and to date it is known from several sites in the Beskid Śląski, one site in the Pilsko massif in the Beskid Wysoki and one site in the Gorce. In addition, it was reported from the Babia Góra massif in the Beskid Wysoki (LIMPRICHT 1890), but, interestingly, LIMPRICHT (1874) did not mention this species in his earlier note on the bryophytes he had collected in this massif. This report is not confirmed by any herbarium specimens, and although the occurrence of $D$. fasciculare in this massif is likely, this species has never been recorded in this massif. The new locality of this species in the Polica Range is therefore its second specimen-based find in the Beskid Wysoki.

"Bucklandiella affinis - it was discovered at a single locality (Fig. 7B). This boreal-montane species is extremely rare in the Polish Carpathians and so far it is known from only one site in the Pogórze Rożnowskie (SZAFRAN 1956 as Racomitrium heterostichum (Hedw.) Brid; BEDNAREK-OCHYRA et al. 1990a; BeDnareK-OchYra 1995) (Fig. 8B). Its newly discovered locality in the Polica Range is therefore the first record of this species in the Polish Carpathians after over 70 years (its first find from the Pogórze Rożnowskie comes from 1946).

Syntrichia latifolia (Figs 9-10) - it was found at a single locality (Fig. 7C). It is a rare epiphytic species, widely scattered on the bark of deciduous trees, but sporadically also inhabiting rocky substrates in the lowlands and foregrounds of the Carpathians and Sudetes, but it is very rare in the mountains. In the Carpathians, it is known only from the Doły Jasielsko-Sanockie, the Pogórze Śląskie, as well as the Beskid Śląski and the Kotlina Żywiecka basin and now the Polica Range completes its Carpathian distribution (Fig. 8C).

Orthotrichum pallens (Fig. 11) - it was recorded at three localities (Fig. 7D). In the Beskidy Zachodnie, it is a very rare epiphytic species, widely distributed but scattered in the Beskid Śląski, Beskid Mały, Beskid Makowski, Beskid Wysoki, in the Pogórze Orawsko-Jordanowskie, the Beskid Saqdecki and the Beskid Niski. In addition, this species is often found in the Pieniny and very rarely in the Skalice Nowotarskie and Spiskie klippen, the Małe Pieniny and in the Tatra. In addition, it is a very rare species in the Pogórze Cieszyńskie, Pogórze Rożnowskie and the Pogórze Wielickie.

Orthotrichum stramineum (Fig. 12) - it was recorded at a single locality only (Fig. 7E). A very rare epiphytic species, occurring in all ranges of the Beskidy Zachodnie and, additionally, it occurs quite often in the Pieniny and the Małe Pieniny and very rarely in the Tatra. Moreover, O. stramineum is rare in the Góry Sanocko-Turczańskie and the Bieszczady Zachodnie in the Polish Eastern Carpathians.

Lewinskya striata (Fig. 13) - it was found at two localities (Fig. 7F). It is a very rare epiphytic species, growing on the bark of deciduous trees, found in several ranges of the Beskidy Zachodnie (Beskid Śląski, Beskid Mały, Beskid Wysoki, Gorce, Pogórze Orawsko-Jordanowskie, Beskid Sądecki, Beskids Niski) (WaCŁawsKa 1957; MamcZarz 1977; Karczmarz 1987; Stebel 2006a, 2017; Stebel \& VonČIna 2014) and now the Polica Range is added to this group. In addition, the species is quite rare in the Małe Pieniny (OchYra \& STEBel 2010), Pieniny (STEBel et al. 2010) and the Tatra (ChalubińsKi 1886; OchYra \& CisŁo 1999), as well as in the Pogórze Ciężkowickie (STEbel \& VonČIna 2017).

Zygodon dentatus (Fig. 15) - it was discovered at a single station only (Fig. 14A). A very rare epiphytic species, occurring in Poland almost exclusively in the Carpathians, primarily in the Beskidy Zachodnie 
(Fig. 16A), while in the Sudetes it was found only once in the Góry Bialskie Mountains. It is also very rare in the Tatra. In the Polish Carpathians, this species shows a considerable disjunction in the Beskid Niski and adjacent parts of the Pogórza Środkowobeskidzkie Foothils, after which it again appears in the Góry Sanocko-Turczańskie and the Bieszczady Zachodnie in the Eastern Carpathians.

Meesia uliginosa - it was collected only once in the study area and it has not been rediscovered since (Fig. 14B). The species is commonly found at high elevations in the limestone Western Tatra and on mylonite rocks in the High Tatra. Outside the Tatra, it was found only once in the Gorce in the Polish Carpathians. The present record in the Polica Range is therefore its second discovery in the Beskidy Zachodnie (Fig. 16B).

Hookeria lucens (Fig. 17) - this very rare and endangered species of moss, which is under strict protection in Poland, was found after many years of special searches at a single locality in the Polica Range (Klama \& OCHYRA 2018) (Fig. 14C). Since the publication of the last distribution map of H. lucens in the Polish Carpathians (SteBel et al. 2004), this species has been found in the Beskid Mały, the Beskid Wysoki, the Gorce, the Beskid Niski (VONČINA 2015; M. SZCZEPAŃSKI, personal communication) and in the Pogórze Przemyskie (D. BuRY, personal communication) in the Polish Western Carpathians as well as in the projected Turnicki National Park in the Eastern Beskidy in the Polish Eastern Carpathians (BURY 2018) and herein an updated map of its distribution is presented (Fig. 16C).

In the moss flora of the Polica Range STEBel et al. (2004) distinguished two groups of species with the lowest frequency in this area, namely very rare species that were recorded at 1-3 sites and rare ones that were collected at 4-8 sites. During recent studies, for 16 species belonging to these two categories additional sites were found and, accordingly, some of them have changed their status regarding their frequency, moving to higher categories.

Sphagnum fimbriatum - apart from S. compactum it is the rarest species of peat moss in the study area which was known only from a single locality. Herein, the species was recorded at a second site (Fig. 14D), but it still represent a category of very rare species. This species is also very rare in other ranges of the Beskidy Zachodnie and Beskidy Środkowe (Beskid Śląski, Beskid Wysoki, Beskid Wyspowy, Gorce, Beskid Niski) and only in the Beskid Mały it occurs more frequently at five localities (Stebel 2010a). In addition, it is very rare in the Pieniny and the Małe Pieniny, but so far it has not been found in the Tatra.

Encalypta streptocarpa (Fig. 18) - a very rare species, known until now only from two localities lying at low altitudes in the lower montane belt. The two new localities are situated at similar elevations, but now it can be treated as a rare species in the Polica Range (Fig. 14E). Elswhere in the Beskidy Zachodnie, E. streptocarpa is a frequent species in the Beskid Ślaski and Beskid Mały or quite frequent in the Kotlina Żywiecka, Beskid Wyspowy and Beskid Wysoki, but in the Gorce, Beskid Makowski and in the Pogórze Orawsko-Jordanowskie it is very rare. In contrast, E. streptocarpa is common throughout the whole calcareous Pieniny Klippen Belt.

Fissidens dubius - until now it has been considered a rare saxicolous species in the Polica Range, known only from four sites scattered at low elevations in the western part of the study area (Fig. 14F). During recent studies, it was discovered at a further five stations and, unexpectedly, it should be considered as quite frequent in this area. In other ranges of the Beskidy Zachodnie it is considered a rare or very rare species and only in the Beskid Wyspowy is quite common. It is also very rare in the Beskid Saqdecki and the Beskid Niski, and in the Tatra it is an infrequent species.

Cynodontium strumiferum - a very rare species, previously recorded at three sites in the Polica Range and thanks to this discovery it should be treated as a rare species in the study area (Fig. 19A). The species is known from all the ranges of the Beskid Zachodnie, except for the Kotlina Żywiecka, but everywhere it is very rare. Recently, it was collected in the Magura National Park in the Beskid Niski, but until now it was not recorded from the Beskid Sądecki and the Tatra.

Didymodon spadiceus - a very rare species which has hitherto been known only from three sites in the Polica Range and the newly discovered locality changed its current status in terms of frequency from very rare to rare (Fig. 19B). In most of the mountain ranges in the Beskidy Zachodnie in which it is known (Beskid Makowski, Kotlina Żywiecka, Beskid Wyspowy, Beskid Wysoki, Pogórze OrawskoJordanowskie) it is a very rare species and only in the Gorce has been recorded at more sites, although it is 
still a rare species here. It is equally rare in the Tatra, the Pieniny and the Skalice Nowotarski and Spiskie and only slightly more frequent in the Małe Pieniny.

Tortula subulata - a rare species, previously reported from four sites in the Polica Range (Fig. 19C). A revision of the herbarium specimen reported from the Polica Range as T. mucronifolia (STEBEL et al. 2004) showed that it actually belongs to T. subulata and was initially considered as a separate variety, var. graeffii (STEBEL 2006a). However, the systematic value of this variety is questionable and it falls well within the range of variation of $T$. subulata. Accordingly, $T$. mucronifolia must be excluded from the moss flora of the Polica Range and automatically from the moss flora of the Beskidy Zachodnie. Tortula subulata is known from all ranges of the Beskidy Zachodnie and it is everywhere a very rare or rare species. It is equally rare in the whole Pieniny Klippen Belt and in the Tatra.

Lewinskya affinis (Fig. 20) - a widely distributed but scattered species throughout the Polish Carpathians. In the Polica Range it was considered a rare species, known so far only from six sites, but the discovery of additional three localities made it a fairly frequent species (Fig. 19D).

Orthotrichum diaphanum (Fig. 21) - until recently, this species was rare in the Polish Carpathians, but now it is known from most regions, especially in their western part. In the Polica Range it is a very rare species, known hitherto from only two sites located in the eastern part of the study area, and herein it is recorded at one additional station (Fig. 19E).

Ulota crispa - a rare epiphytic species, growing on the bark of deciduous trees and shrubs in the foothills and in the lower montane belts. Until now, he was known for five stations and four additional ones are provided in this article, making it a fairly frequent species (Fig. 19F). One of them was found at an altitude of $1050 \mathrm{~m}$ a.s.l. and it is the second highest location of $U$. crispa in the Beskidy Zachodnie. The highest site of this species in these mountains was found at an altitude of $1100 \mathrm{~m}$ a.s.l. in the Gorce, while in the Polish Carpathians the highest locations are known from the Tatras, where it reaches a maximum altitude of $1460 \mathrm{~m}$ a.s.l. Generally, until recently $U$. crispa was a very rare species in the Beskidy Zachodnie but, currently, the species is more and more frequently recorded, and the number of its localities is growing rapidly.

Mnium hornum (Fig. 22) - a very rare species, found so far in the Polica Range on two sites (Fig. 23A). It is equally rare in the entire Beskid Wysoki, Beskid Wyspowy, Gorce, Beskid Sądecki and Pogórze Orawsko-Jordanowskie, but common in the Beskid Śląski, frequent in the Beskid Mały and the Beskid Niski, and fairly frequent in the Kotlina Żywiecka and the Beskid Makowski.

Mnium spinosum - so far it was considered to be a very rare species in the study area but now it is recorded from two additional localities, making it a rare species (Fig. 23B). In the Beskid Zachodnie, M. spinosum is generally a very rare species, known only from the Beskid Śląski, Beskid Wysoki, Beskid Mały, Gorce, Pogórze Orawsko-Jordanowskie and Beskid Sądecki. However, it is a frequent species in the Skalice Nowotarsko-Spiskie klippen and in the Tatra.

Neckera besseri - a very rare species in the Polica Range known hitherto only from a single site on the Łysina cliff east of Złota Grapa (Fig. 23C). It is also a very rare species in the whole Beskidy Zachodnie (Beskid Śląski, Beskid Makowski, Beskid Wysoki, Beskid Wyspowy, Gorce, Beskid Sądecki). In the Polish Carpathians, this basiphilous species is most often found only in the Pieniny Klippen Belt and besides it was only sporadically recorded in the Beskid Sądecki, Beskid Mały and Beskid Niski.

Neckera complanata - a species reported from many regions of the Polish Carpathians. It was recorded from three localities in the Polica Range (Fig. 23D). In the Jaworzyna Valley, it has already been observed at an altitude of $740 \mathrm{~m}$ a.s.l. (STEBEL et al. 2004), and during the present study the species was rediscovered at this locality, although the specimens were collected at a slightly higher place.

Thamnobryum alopecurum (Fig. 24) - a very rare species in the Polica Range, known only from one site at Hala Krupowa in highest parts of the main ridge (Fig. 23E). The newly discovered site of this species, located in the Skawica Górna Stream is extremely rich and this species grows here in masses on the blocks in the stream bed. This basiphilous species occurs most often in the Pieniny Klippen Belt and only sporadically in the Beskid Śląski, Beskid Sądecki, Beskid Mały and Beskid Niski. The record of Th. alopecurum from the projected Turnicki National Park (BURY 2018) needs confirmation.

Heterocladium heteropterum - a very rare saxicolous species, previously known only from three sites, including two located in the highest parts of the Polica Range (Fig. 23F). Two new sites have been found 
on shaded sandstone boulders in spruce forests. Nevertheless, it still remains a rare species in this range, as is the case in the Gorce, the Beskid Wyspowy and the Beskid Wysoki. Only in the Beskid Ślaski and the Beskid Mały $H$. heteropterum was more often found but it is very rare in the Tatra and in the Beskid Niski. Recently, it was also found in the Pogórze Rożnowskie in the "Styr" Nature Reserve .

Rhytidiadelphus subpinnatus (Fig. 25) - a rare forest species, known until now only from six sites, clustered in the upper parts of the lower montane belt and in the upper montane belt. New localities were found in the lower parts of the lower montane belt, in well preserved patches of the spruce forest, where this moss grows in abundance. In other ranges in the Beskidy Zachodnie this species occur with similar frequency, ranging from very rare in the Beskid Makowski, Beskid Wyspowy and Kotlina Żywiecka, through rare in the Gorce and Pogórze Orawsko-Jordanowskie and fairly frequent in the Beskid Wysoki to frequent in the Beskid Śląski. To date, To date, it has not been recorded from the Beskid Mały.

The biodiversity of the moss flora in the Beskidy Zachodnie is discussed in the historical context considering various periods of the bryological exploration of their particular mountain ranges. At present, the richest moss flora in these mountains has the Beskid Wysoki (355 species, 1 subspecies and 11 varieties) which is followed by the Beskid Śląski (304 species and 3 varieties), the Gorce (286 species +9 varieties), the Beskid Mały (260 species and 8 varieties), the Kotlina Żywiecka (234 species and 6 varieties), the Beskid Wyspowy (233 species and 5 varieties) and the Beskid Makowski (232 species and 4 varieties).

Thanks to the discovery of 15 further new species and at the same time the deletion of one species (Tortula mucronifolia), the moss flora of the Polica Range consists currently of 278 species and five varieties. In this context, statistics of the floristic richness of mosses within the Beskid Wysoki itself is very interesting. This largest range within the Beskidy Zachodnie includes four smaller physiographic units: the Pamo Babiogórskie Range consisting of the Babia Góra massif and the Polica Range, the Beskid ŻywieckoOrawski, which is also called the Pilsko and Wielka Racza group, and the Pogórze Orawsko-Jordanowskie Foothills, also known as the Działy Orawskie Hills with the Pasmo Podhalańskie Range. As a whole, the Beskid Wysoki has the richest moss flora in the Beskidy Zachodnie, numbering 355 species, one subspecies and 11 varieties. Within it, the richest flora of mosses has the Babia Góra massif - 280 species (STEBEL et al. 2018; Ellis et al. 2019a). Only two species less has the Polica Range, whilst in the Beskid ŻywieckoOrawski 269 species, one subspecies and five varieties have been recorded (STEBEL, unpublished) and in the Pogórze Orawsko-Jordanowskie 241 species and ten varieties are known (STEBEL \& VonČINA 2014). There are five species of moss, namely Schistidium elegantulum, S. trichodon var. trichodon, Bucklandiella affinis, Syntrichia latifolia and Meesia uliginosa which are known exclusively in the Polica Range and which have not hitherto been detected in other part of the Beskid Wysoki.

If one considers the floristic richness of the Beskidy Zachodnie in the context of these physiographic units, quite unexpectedly the largest biodiversity of the moss flora occurs in the Beskid Śląski (304 species +3 varieties) and in the Gorce (286 species +9 varieties). The third position in this ranking is occupied by the Babia Góra massif ( 280 species +1 subspecies +7 varieties), which theoretically should have the richest muscoflora, at least because of the presence of the alpine zone, in which some altimontane species occur, which are known only from the Tatra in the Polish Carpathians. Just behind these physiographic units, the Polica Range ranks the fourth position with 278 species and five varieties. However, the above statistics can easily change, especially after further detailed field studies in the Babia Góra massif, where the alpine zone should yield some additional high-mountain species.

Wptynęto: 21.05.2020 r.; przyjęto do druku: 10.07.2020 r. 